INTERNATIONAL MONETARY FUND

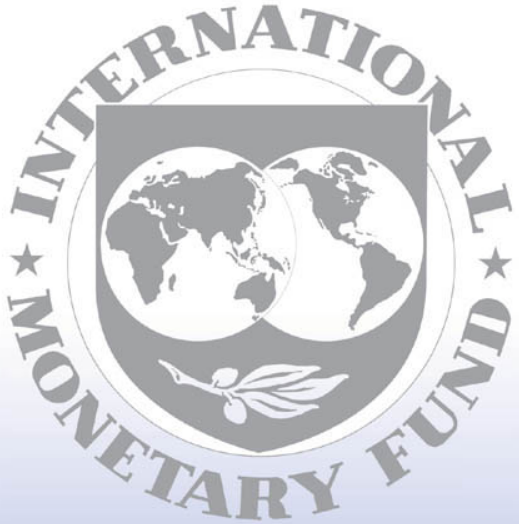

Staff

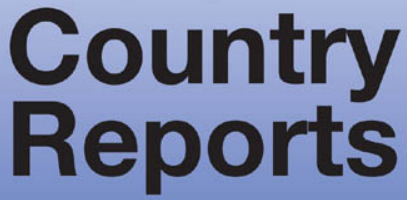




\section{Israel: 2007 Article IV Consultation-Staff Report; Staff Supplement; Public Information Notice on the Executive Board Discussion; and Statement by the Executive Director for Israel}

Under Article IV of the IMF's Articles of Agreement, the IMF holds bilateral discussions with members, usually every year. In the context of the 2007 Article IV consultation with Israel, the following documents have been released and are included in this package:

- $\quad$ The staff report for the 2007 Article IV consultation, prepared by a staff team of the IMF, following discussions that ended on December 10, 2007, with the officials of Israel on economic developments and policies. Based on information available at the time of these discussions, the staff report was completed on January 22, 2008. The views expressed in the staff report are those of the staff team and do not necessarily reflect the views of the Executive Board of the IMF.

- A staff supplement of February 8, 2008 updating information on recent developments.

- $\quad$ A Public Information Notice (PIN) summarizing the views of the Executive Board as expressed during its February 13, 2008 discussion of the staff report that concluded the Article IV consultation.

- $\quad$ A statement by the Executive Director for Israel.

The document listed below has been or will be separately released.

Selected Issues Paper

The policy of publication of staff reports and other documents allows for the deletion of market-sensitive information.

To assist the IMF in evaluating the publication policy, reader comments are invited and may be sent by e-mail to publicationpolicy@imf.org.

Copies of this report are available to the public from

International Monetary Fund $\bullet$ Publication Services

$70019^{\text {th }}$ Street, N.W. • Washington, D.C. 20431

Telephone: (202) 623-7430 • Telefax: (202) 623-7201

E-mail: publications@imf.org • Internet: http://www.imf.org

Price: $\$ 18.00$ a copy

International Monetary Fund

Washington, D.C. 
This page intentionally left blank 


\section{INTERNATIONAL MONETARY FUND}

\section{ISRAEL}

\section{Staff Report for the 2007 Article IV Consultation}

Prepared by the Staff Representatives for the 2007 Consultation with Israel Approved by Michael Deppler and Michael Hadjimichael

January 22, 2008

\section{EXECUTIVE SUMMARY}

Economic growth and policies have been strong but vulnerabilities remain. There was agreement between staff and the authorities on the major issues. The key points are as follows:

- $\quad$ Economic growth is projected to remain strong in 2008, although less buoyant than in the recent past. Domestic fundamentals are solid, except that capacity constraints are beginning to bind and risk premia have increased. Slowing demand in partner countries is expected to weigh on activity.

- Interest rates would probably have to rise to keep inflation in the 1-3 percent target range over the medium run. But downside risks to external demand and higher risk premia argue for caution in raising rates.

- $\quad$ The 82 percent of GDP public debt ratio is a key source of economic vulnerability. Given that good times are expected to prevail, the central government deficit should stay at the close-to-balanced position achieved in 2007 to support a rapid decline of the debt ratio. This will require tight execution of the 2008 budget, which tables a ceiling of 1.6 percent of GDP for the central government deficit, and allocating revenue overperformance to deficit reduction.

- $\quad$ The present rules-based approach to fiscal policy has served the country well and should be preserved. An increase in the relatively low expenditure growth ceiling is under consideration. Staff argued for anchoring a revised rule also on a 60 percent of GDP debt objective for 2015. Achieving this objective would require maintaining the close-to-balanced central government position through 2015. The authorities thought that this was a realistic target that was consistent with higher expenditure growth and would be considered.

Financial sector soundness has been improving and a more diversified and complex system is emerging as a result of ambitious reforms. This will require a commensurate strengthening of prudential policies and practices. Key are more scope to recruit highly qualified staff; rebalancing activities from developing new regulation to on-site supervision; taking a more principles-based approach to regulation; enhancing collaboration between the supervisors, notably with respect to crisis management and resolution; and formal independence for the insurance supervisor. 
Executive Summary

I. Report on the Discussions

A. Macroeconomic Prospects: Strong but Less Buoyant Activity ……......................... $\underline{3}$

B. External Prospects: More Integration with the World Economy ………………....... $\frac{5}{5}$

C. Monetary Policy: Staying on Target Amid Exchange Rate Volatility ........................ 6

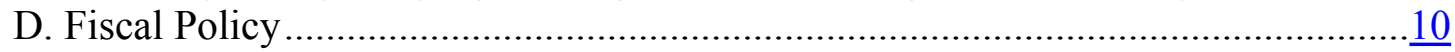

E. Managing the Transformation of the Financial System .........................................13

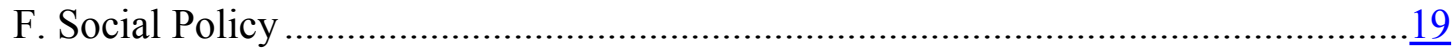

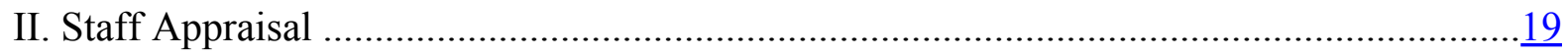

Figures

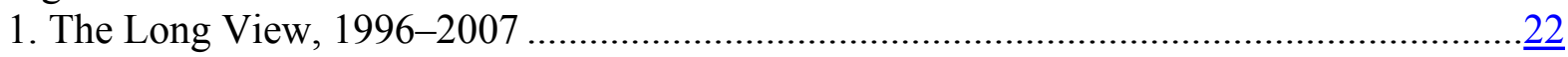

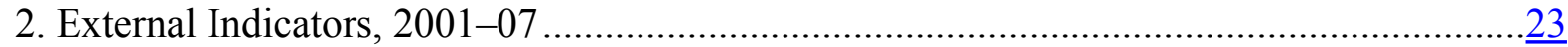

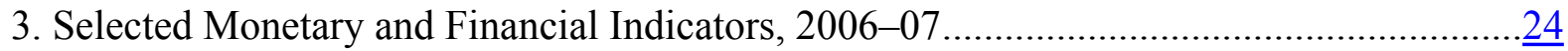

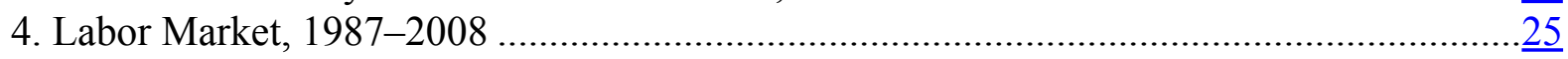

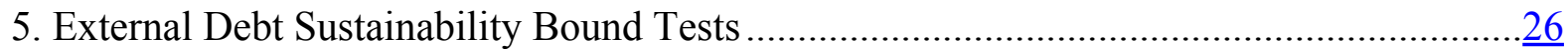

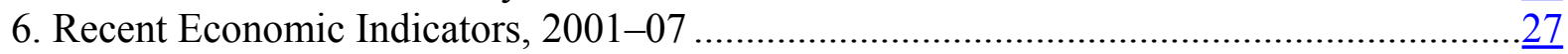

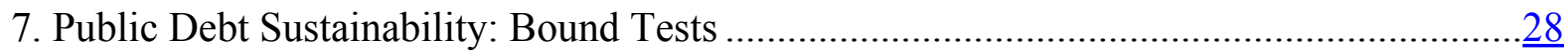

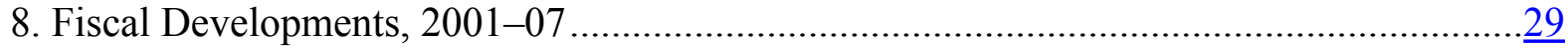

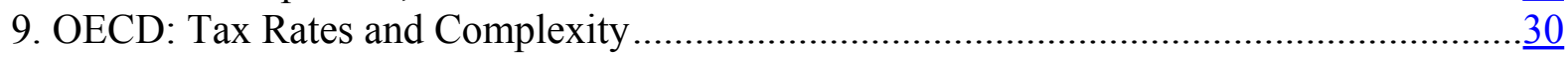

Tables

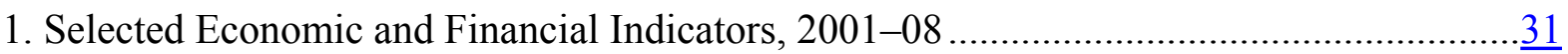

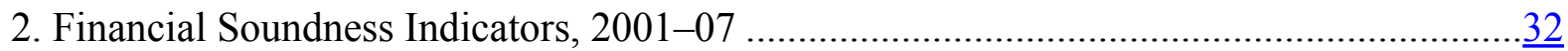

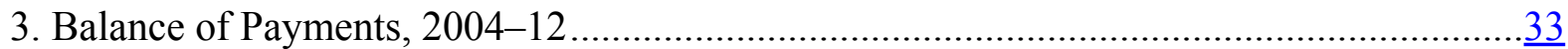

4. Indicators of External and Financial Sector Vulnerability, 2001-07 ................................

5. External Debt Sustainability Framework, 2002-12 ……............................................

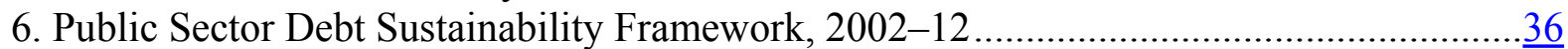

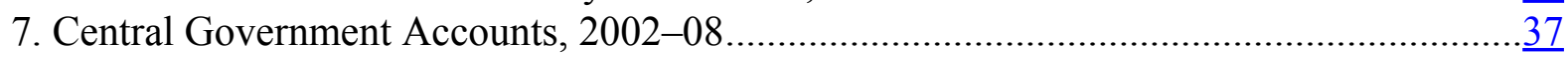

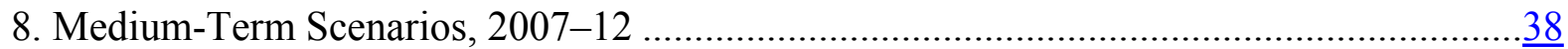

Boxes

1. Monetary Policy—Baseline Forecast and Risk Assessments ............................................. $\underline{9}$

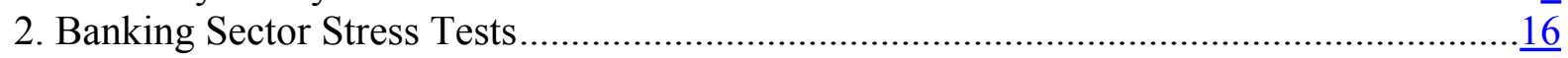




\section{REPORT ON THE DISCUSSIONS}

1. Strong macroeconomic conditions and sound domestic policies have significantly improved Israel's growth performance and prospects but vulnerabilities remain. ${ }^{1}$ Amid global financial market turmoil and heightened uncertainty about growth prospects, the discussions focused on external stability and the exchange rate; financial sector vulnerabilities and policy requirements; and fiscal policy, notably the need to reduce the high public debt.

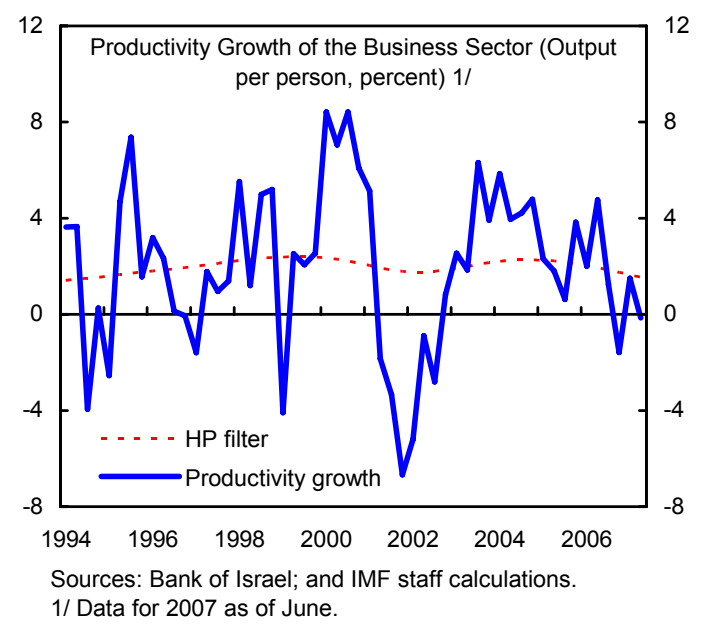

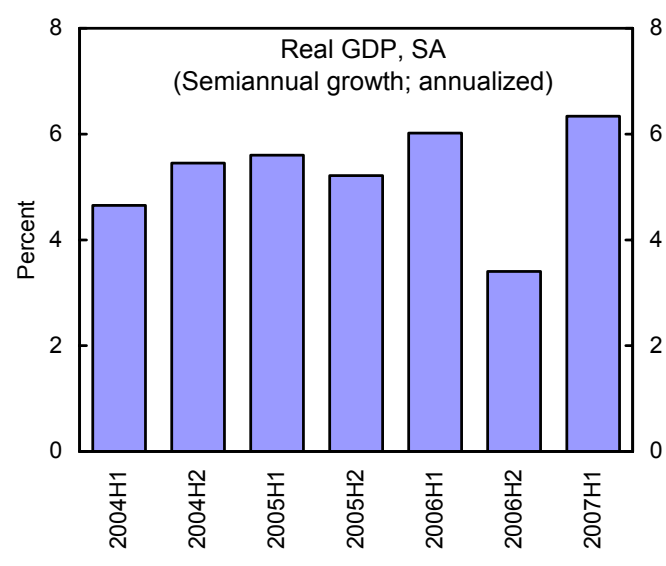

Sources: Central Bureau of Statistics; and IMF staff estimates.

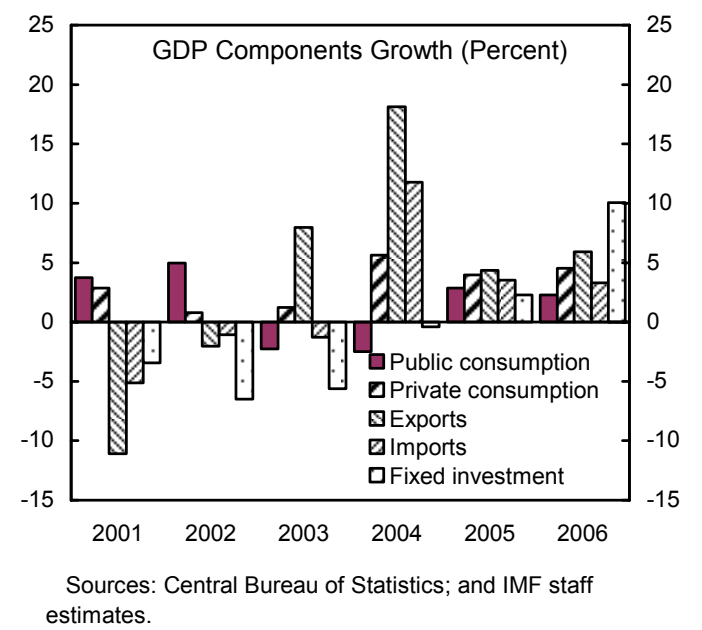
estimates.

\section{A. Macroeconomic Prospects: Strong but Less Buoyant Activity}

2. The economy is entering the global slowdown with significant momentum.

Notwithstanding the war in the north during 2006, real GDP growth averaged about 51/4 percent during 2006-07 (Table 1, Figure 1). Buoyant world trade propelled exports and investment, fostering strong employment growth—which was also supported by welfare reform-and private consumption.

3. The global financial turmoil has caused some increase in risk premia but has not prompted significant concerns thus far (Figure 2-3 Tables 2-4). Stock prices have been

\footnotetext{
${ }^{1}$ The staff team that met with the authorities comprised Messrs. Decressin (head), Čihák, Epstein (all EUR), Moore and Tower (MCM), and Palmer (MCM Consultant). Israel is a case study for enhanced financial sector analysis.
} 
resilient in the face of recent financial turbulence; CDS spreads on government bonds are up somewhat from unusually-low pre-crisis levels; and corporate bond spreads have widened, reflecting also the bankruptcy of a local nonfinancial firm. Some banks have announced losses on mortgage-related US assets but the effect on profitability and capital has been small. Nor have banks been experiencing funding pressures, as they rely almost exclusively on deposits from the public. The authorities do not expect a fall-out of the financial turmoil on the Israeli banking system that could affect its ability to adequately support the domestic economy, provided losses on AAA-rated prime-mortgage-

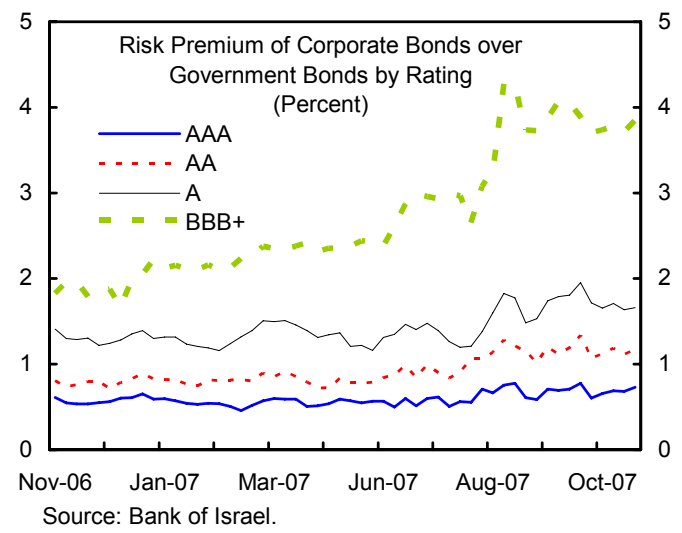
backed securities (ABS) remain limited. ${ }^{2}$

\section{Looking forward, activity is thus widely expected to remain strong, even if} somewhat less buoyant than in the past. Domestic preconditions for continued output growth remain in place. Specifically, GDP growth is broad based; families' real incomes are rising, including those of the poor; corporate profitability and balance sheets have improved; and the cooperation between employers and trade unions is good. Furthermore, the economy’s competitiveness is still solid ( $\$ 7)$. However, capacity constraints are beginning to bind (Figure 4), notably in the market for highly skilled employees; and risk premia on corporate funding have risen. Also, external conditions are becoming less supportive. In particular, decelerating activity in the United States and Europe will weigh on exports and investment, although much hinges on the extent to which the external slowdown spreads beyond foreign real estate sectors; and oil prices are standing some 40 percent above 2007:Q1 levels. Accordingly, the Ministry of Finance (MoF) and Bank of Israel (BoI) foresee 4.2 percent and 4.4 percent real GDP growth, respectively, for 2008. Taking into account the latest developments and prospects, staff projects 3.8 percent real GDP growth, which is around potential, and an output gap that is estimated to be broadly closed. ${ }^{3}$

5. Risks around the forecasts were seen to be broadly balanced. MoF staff felt that their forecast was prudent, considering repeated upside surprises to growth in the past. BoI

\footnotetext{
${ }^{2}$ Banks were instructed to disclose their holdings of US mortgage-related assets by September 30, 2007. According to the disclosures by the largest five banks (which account for almost all banking system assets), holdings of structured products, which are being hit by write offs, amounted to 0-12 percent of equity; those of ABS that are not guaranteed by US government-sponsored enterprises amounted to 3-11 percent of equity for four banks and 75 percent of equity for one bank (Hapoalim). All the banks have reported that they have no (or minimal) exposure to sub-prime mortgages in their ABS portfolios. Hapoalim reported that 99 percent of its holdings of ABS are AAA-rated. Mark-to-market losses on these types of assets have to date been modest.

${ }^{3}$ This assumes steady-state productivity growth of 2 percent, with population growth at $13 / 4$ percent.
} 
staff explained that under an alternative scenario, with the United States experiencing a recession, growth would still reach 3.6 percent. The authorities concurred that external risks are tilted to the downside: partner demand might slow more than expected, global financial turmoil might worsen and begin to affect Israel significantly, oil prices could exceed projections further, and rising geopolitical uncertainty could adversely affect output. But domestic risks are to the upside. In particular, despite unemployment rates nearing record lows and wages accelerating gradually, capacity might be less constraining than estimated.

\section{B. External Prospects: More Integration with the World Economy}

\section{The economy is integrating rapidly with the rest of the world. Flows of} nonresident investment into Israel — spurred partly by privatization of public enterprisesand resident investment abroad together reached a record 40 percent of GDP in 2006, up from 22 percent of GDP in 2005, partly on account of some exceptionally large transactions. In 2007, gross flows are moderating toward 2006 levels. The increased flows have also pushed gross external debt to about 60 percent of GDP but this does not detract appreciably from robustness. While this raises vulnerability to exchange rate shocks (Figure 5, Table 5), this vulnerability is greatly diminished by the country's net external debt asset position of about 25 percent

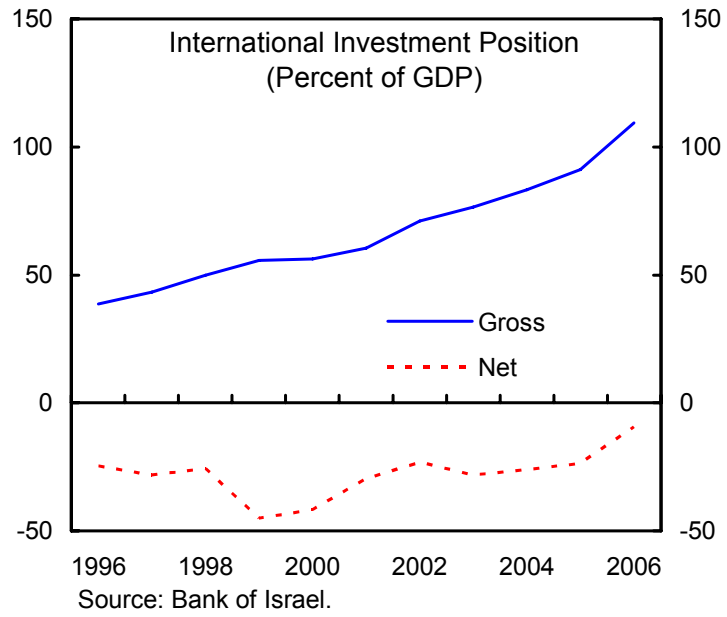
of GDP. Only the public sector has net external debt liabilities, equivalent to some 3 percent of GDP.

\section{The current account surplus is falling} but the exchange rate may still be moderately undervalued. The current account surplus reached 51/2 percent of GDP in 2006, up from 3.3 percent in 2005 . While domestic investment has been recovering strongly, public savings have been rebuilt. Concurrently, temporary factors are boosting private savings and the current account, notably the 2005 tax reform on investments abroad, which has fostered record capital outflows. At a constant real effective exchange rate and based on data available through end-November 2007, staff

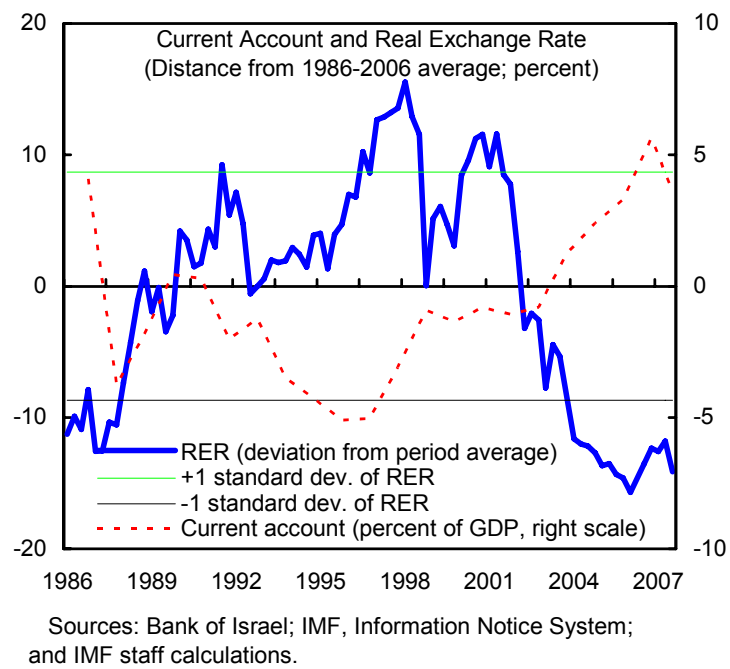
and BoI projections point to a decline in the current account surplus to $2 \frac{1}{2}$ percent of GDP by 
2008. Staff sees the current account stabilizing at $2 \frac{1}{4}$ percent of GDP over the medium run. Multilateral calculations point to an equilibrium current account ("norm") of about 1 percent of GDP for Israel and suggest that the real exchange rate may be undervalued by 510 percent, although the "norm" and the underlying current account could be closer together. ${ }^{4}$ Consistent with such a view, the balance for goods and services has not moved much during 2004-06 and market shares for goods have moved broadly sideways.
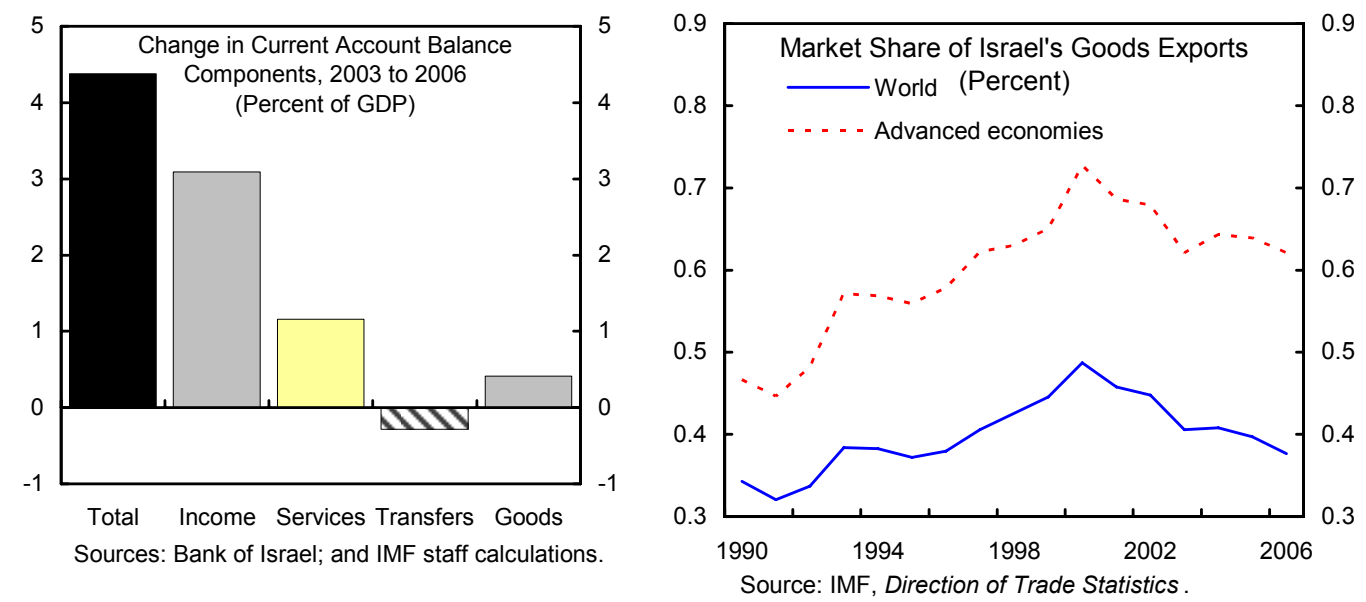

8. The authorities had no firm view on the valuation of the exchange rate. There was agreement that domestic policies are consistent with external stability. However, the authorities considered it difficult to determine the medium-run equilibrium current account balance and exchange rate with much confidence. BoI analysis suggests that the former is higher and the latter more appreciated than over the 1990s. Also, BoI representatives thought that talk about under or overvaluation could prompt calls for renewed intervention in exchange markets (BoI last intervened in 1997), which could complicate monetary policy. The flexible exchange rate regime was viewed to be appropriate for Israel. Also, any undervaluation would allow scope for nominal appreciation, which would help moderate inflationary pressure $(\boldsymbol{\Phi} 10)$.

\section{Monetary Policy: Staying on Target Amid Exchange Rate Volatility}

\section{Monetary policy has successfully stabilized inflation expectations, even though} inflation has frequently been outside the 1-3 percent target range on account of exchange rate changes. Lately, inflation has been undershooting the 1-3 percent target, largely reflecting sheqel appreciation against the US dollar, but is rising again. By November, prices stood just under 3 percent above the end-2006 level (Figure 6), while the sheqel (NIS) appreciated by about 6.5 percent against the US dollar (US\$), which may have

\footnotetext{
${ }^{4}$ See Selected Issues Paper, Chapter I.
} 
lowered domestic prices by about 2 percent. ${ }^{5}$ As the exchange rate prompted CPI deflation earlier in the year, the BoI responded by cutting interest rates from a peak of 5.5 percent in October 2006, to 3.5 percent by June 2007 . The rate cuts to below the U.S. federal funds rate (an unprecedented differential) contributed to weakening the shekel. With inflation reaccelerating, falling unemployment and rising wage pressure, and some evidence of slowing productivity growth, the BoI changed course in August, raising rates in three steps, to 4.25 percent by January 2008 .

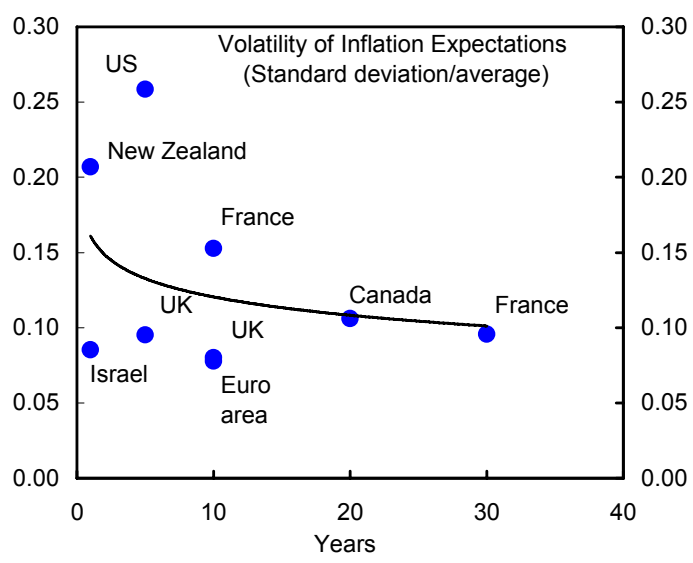

Sources: Bloomberg; and IMF staff calculations.

\section{Further rate hikes will probably be needed for inflation to stay within the 1-3} percent target range, with the amount depending on exchange rate developments. Monetary policy will have to contend with rising domestic pressures on inflation and a volatile exchange rate. BoI econometric estimates suggest that the domestic component of consumer prices is rising over 4 percent, while the external component is declining, owing to the appreciation of the sheqel against the U.S. dollar. Judging by current developments and with prospects for rising capacity constraints, domestic inflationary pressure is unlikely to moderate in the context of a policy rate that is not firmly within neutral range. Also, global inflation is on the rise. Thus, much will hinge on the development of the NIS/US\$ exchange rate. In this regard, there was agreement that, because the current account surplus would probably narrow fundamental pressures for sheqel appreciation would diminish. Furthermore, BoI officials expected capital inflows to moderate more than outflows, as diversification by institutional investors would continue. Market analysts foresee inflation of just over 2 percent over the medium
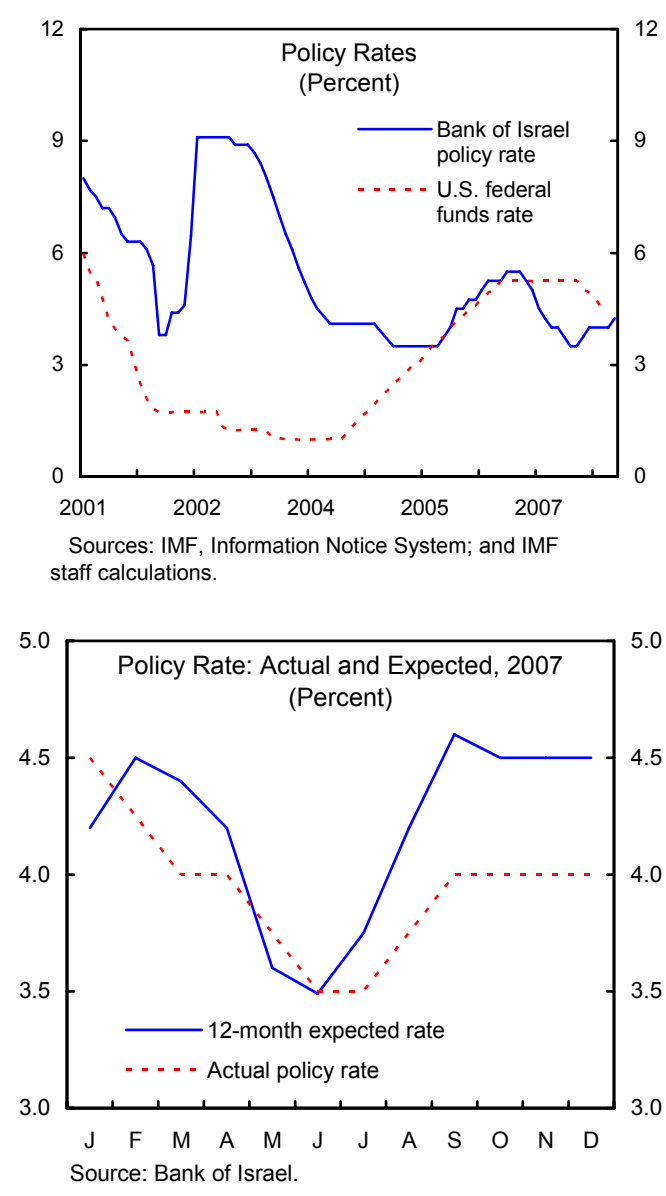

\footnotetext{
${ }^{5}$ A 10 percent appreciation against the US\$ quickly reduces inflation by about 2 percent because housing and some other services are priced in US\$, and account for roughly 20 percent of the CPI basket.
} 
run, with the policy rate rising to around 4.5 percent by 2008:Q4. Staff's forecast based on the WEO and other tools is for inflation of around 2 percent in 2008-09, assuming interest rates rise gradually to about 5.0 percent by end-2009. However, the risks around this scenario, particularly on account of the potential for a further appreciation of the exchange rate, remain appreciable (Box 1). More importantly, there was agreement that growing uncertainty about external demand prospects and rising risk premia in capital markets argue for caution in raising rates.

\section{Staff welcomed steps to strengthen the transparency of the monetary policy} framework and discussed options for further improvements. The BoI is moving to publish inflation reports on a quarterly rather than semi-annual frequency to improve communication with markets. In addition, model-based fan charts of inflation and interest projections have been added to the report. Staff welcomed these steps, but suggested clarifying the role of the fan chart forecasts, which are not considered official BoI forecasts, in the BoI's decision making; the relationship between these forecasts and those for other macroeconomic variables (notably the exchange rate); and the monetary policy horizon. BoI officials were open-minded, but also had concerns about publishing a formal, full-fledged inflation forecast. They thought that the volatility of the exchange rate and its high (although weakening) pass through to domestic prices would limit the informational content of such a forecast. Nonetheless, they stood ready to alter their communications, notably when restructuring the BoI following the adoption of the draft BoI law. ${ }^{6}$

\footnotetext{
${ }^{6}$ In December 2007, the MoF and BoI formally agreed on a new wage agreement that should pave the way for passage of the new BoI law. For details on the law, see IMF Country Report No. 06/120, para. 23.
} 


\section{Box 1. Monetary Policy—Baseline Forecast and Risk Assessments}

The central scenario assumes a small positive output gap that is expected to close by mid2008. Under this scenario, and at an exchange rate of about 3.9 shekel $/ \$$, the policy rate would be expected to rise in order to maintain headline inflation within the $1-3$ percent band over the next two years.

\begin{tabular}{lrrr}
\multicolumn{4}{c}{ Baseline Forecast on December 17, 2007} \\
\hline & 2008Q1 & 2008Q4 & \multicolumn{2}{c}{2009} \\
\hline Policy rate & 4.3 & 4.8 & 5.1 \\
Inflation & 2.6 & 1.0 & 2.0 \\
Sheqel per U.S. dollar & 3.83 & 3.82 & 3.9 \\
Output gap & 0.3 & -0.6 & -0.3 \\
\hline
\end{tabular}

The baseline forecast is subject to a number of risks, the policy implications of which are illustrated below (IMF Country Report 06/121, Chapter III provides detailed explanation and properties of the model used to derive these assessments).

Negative Output Gap

- $\quad$ Unexpected slack, resulting in negative output gap, would alleviate the need to increase the policy rate in the near term, while keeping headline inflation within the targeting band.

(Deviation from baseline)

\begin{tabular}{lrrr}
\hline & 2008Q1 & 2008Q4 & 2009 \\
\hline Policy rate & -0.9 & -0.9 & -0.1 \\
Inflation & 0.0 & -0.1 & -0.1 \\
Sheqel (percent change) & -0.5 & -1.8 & -1.8 \\
Output gap & -2.0 & -0.5 & 0.0 \\
\hline
\end{tabular}

Lower Risk Premium/Sheqel Appreciation

- $\quad$ Continued sheqel appreciation (against USD), coupled with compression in Israel's risk premium, would also alleviate the need for higher policy rate in the near term.

\section{- $\quad$ A 25 percent increase in oil prices} from current projected levels would require acceleration in the policy rate hikes, relative to baseline.

\begin{tabular}{lrrr}
\multicolumn{4}{c}{ (Deviation from baseline) } \\
\hline & 2008Q1 & 2008Q4 & 2009 \\
\hline Policy rate & -0.7 & -0.4 & -0.2 \\
Inflation & -0.3 & -0.2 & -0.1 \\
Sheqel (percent change) & 3.0 & 1.1 & 0.8 \\
Output gap & -0.1 & 0.0 & 0.0 \\
\hline
\end{tabular}

Higher Oil Prices

(Deviation from baseline)

\begin{tabular}{lrrr}
\hline & 2008Q1 & 2008Q4 & \multicolumn{2}{l}{2009} \\
\hline Policy rate & 0.3 & 0.5 & 0.4 \\
Inflation & 0.2 & 0.1 & 0.1 \\
Sheqel (percent change) & 0.7 & 0.7 & 1.0 \\
Output gap & 0.0 & -0.1 & -0.2 \\
\hline
\end{tabular}




\section{Fiscal Policy}

\section{The key challenge for fiscal policy is to keep the public debt ratio firmly on a} downward path. Public debt, which exceeded 95 percent of GDP in 2005, is expected to fall to 82 percent of GDP by end-2007, still very high for one of the most vulnerable advanced economies. The 2001-03 downswing - which resulted from a confluence of global and security developments - is a stark reminder of this vulnerability, as the public debt ratio, which had been on a downward trend since the early 1990s, swung upward by 15 percentage points, to 102 percent of GDP. The Debt Sustainability Analysis (DSA) suggests that this vulnerability remains significant (Figure 7, Table 6).

\section{Near-term requirements}

\section{Fiscal outturns have been much stronger than budgeted over the past couple of} years (Figure 8, Table 7). This is mainly because higher-than-projected revenue has been allocated to debt reduction, but also because war-related expenditure has been offset through expenditure cuts, contrary to budget plans to accommodate such spending. As a result, the central government deficit has been kept well below the 3 percent of GDP deficit ceiling, falling to 1 percent of GDP in 2006 and approaching balance in 2007.7

\section{The authorities are confident that they can stay on the path of debt reduction,} notwithstanding growing pressures for more spending. The central government deficit ceilings are 1.6 percent and 1.0 percent of GDP for 2008 and 2009 respectively. The 2008 budget foresees no more than 1.7 percent real expenditure growth over the 2007 budget. In line with present law, this excludes the last installments of spending on account of the 2006 war and West Bank/Gaza disengagement, which sum to about $1 / 2$ percent of GDP. At the same time, previously programmed tax cuts for 2008 are estimated to remove about 1 percent of GDP from revenue. However, with the latest data suggesting continued higher-than-expected revenue buoyancy, the mission's interlocutors generally expected a deficit below 1 percent of GDP for 2008, assuming economic activity did not disappoint. The mission

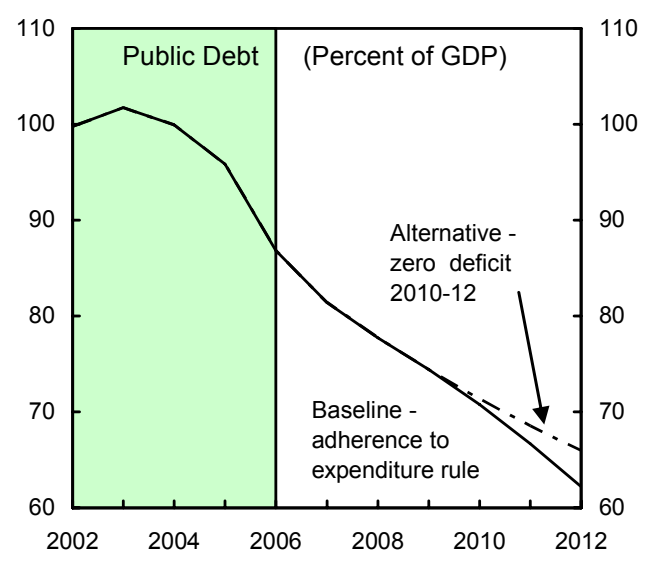
argued that in the current period of good times a widening of the government deficit should be avoided. Accordingly, revenue overperformance should serve deficit and debt reduction, a message with which the authorities agreed.

\footnotetext{
${ }^{7}$ The general government deficit is projected to fall to 1 percent in 2007.
} 


\section{Medium- and long-term challenges}

\section{The current fiscal rule-specifically, the ceiling on real expenditure growth of} 1.7 percent-is considered unsustainable, and a search for a new rule is underway. The current real expenditure growth ceiling entails a continuous slimming of the public sector, given the economy's potential growth rate of $33 / 4$ percent of GDP. There are complaints about compressed welfare spending - nondefense spending is already lower than in many advanced economies - and rising inequality/poverty, but there are also pressures for more tax cuts.

\section{The authorities are considering changes for $\mathbf{2 0 0 9}$ and beyond, in the context of a} revised rules-based approach to fiscal policy. Staff advised anchoring a revised fiscal rule on the objective of lowering the public debt to 60 percent of GDP by $2015 .{ }^{8}$ This objective also featured prominently among plans under discussion in various quarters, including at the National Economic Council, an advisory body to the Prime Minister. Achieving this objective would require maintaining a broadly balanced central government budget, implying general government budget deficits of about 1 percent of GDP through 2015 (Table 8). This objective would be consistent with more expenditure growth, with how much being dependent on future tax relief plans. The authorities considered the 60 percent $/ 2015$ objective realistic and would consider it. They stressed that a higher than 1 percent of GDP central government deficit-which is the ceiling planned for 2009-was currently not under consideration for the medium-run, and that they

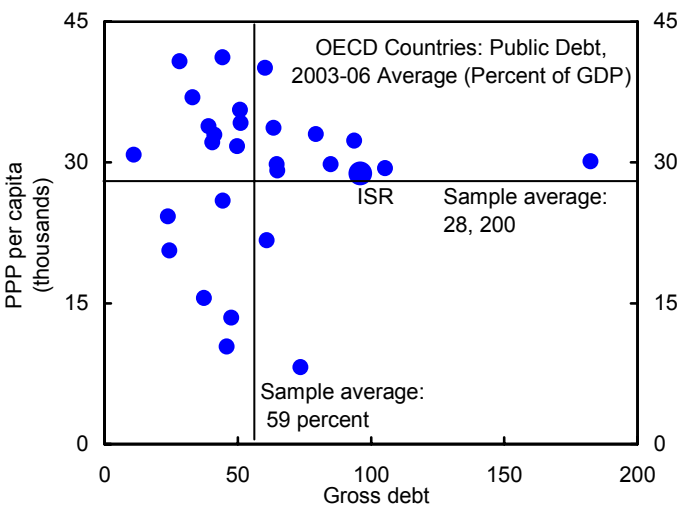

Sources: IMF, World Economic Outlook; and IMF staff calculations. would want to continue overperforming against deficit ceilings. Various expenditure growth rate ceilings would be discussed, bearing in mind that further tax relief was desirable. Staff underscored that debt reduction needed to be given precedence over tax cuts, considering also that, unlike the debt, present tax rates are not out of line with those in most OECD countries. Instead, efforts should focus on simplification of what is an overly complex tax system, including by reducing tax exemptions (Figure 9).

\footnotetext{
${ }^{8}$ See Selected Issues Paper, Chapter IV.
} 
Fiscal Projections for the Central Government, 2006-12 1/

\begin{tabular}{|c|c|c|c|c|c|c|c|}
\hline \multicolumn{8}{|c|}{ (Percent of GDP) } \\
\hline & 2006 & 2007 & 2008 & 2009 & 2010 & 2011 & 2012 \\
\hline \multicolumn{8}{|c|}{ Baseline $(\exp g=1.7 \%)$} \\
\hline Revenue & 35.2 & 36.1 & 35.8 & 35.4 & 35.1 & 35.1 & 35.1 \\
\hline Expenditure & 36.2 & 36.1 & 36.2 & 35.5 & 34.8 & 34.1 & 33.4 \\
\hline CG Balance 2/ & -1.0 & 0.0 & -0.4 & 0.0 & 0.4 & 1.1 & 1.7 \\
\hline GG Balance & -1.8 & -0.8 & -1.3 & -0.9 & -0.5 & 0.2 & 0.9 \\
\hline Public Debt & 86.8 & 81.4 & 77.7 & 74.4 & 70.8 & 66.7 & 62.2 \\
\hline \multicolumn{8}{|c|}{ Alternative (zero CG def 2010-12) } \\
\hline Revenue & 35.2 & 36.1 & 35.8 & 35.4 & 35.1 & 35.1 & 35.1 \\
\hline Expenditure & 36.2 & 36.1 & 36.2 & 35.5 & 35.1 & 35.1 & 35.1 \\
\hline CG Balance & -1.0 & 0.0 & -0.4 & 0.0 & 0.0 & 0.0 & 0.0 \\
\hline GG Balance & -1.8 & -0.8 & -1.3 & -0.9 & -1.1 & -1.0 & -1.0 \\
\hline Public Debt & 86.8 & 81.4 & 77.7 & 74.4 & 73.9 & 71.1 & 68.6 \\
\hline
\end{tabular}

Source: IMF staff estimates and projections.

$1 /$ Staff baseline projections (excludes credit).

2/ Baseline scenario assumes 1.7 percent growth in real expenditure, excluding war-related spending in 2007-08.

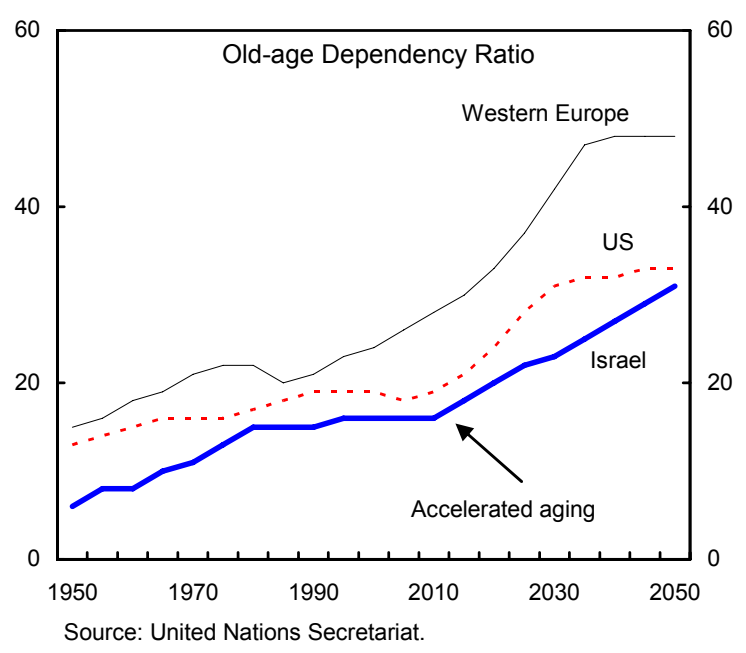

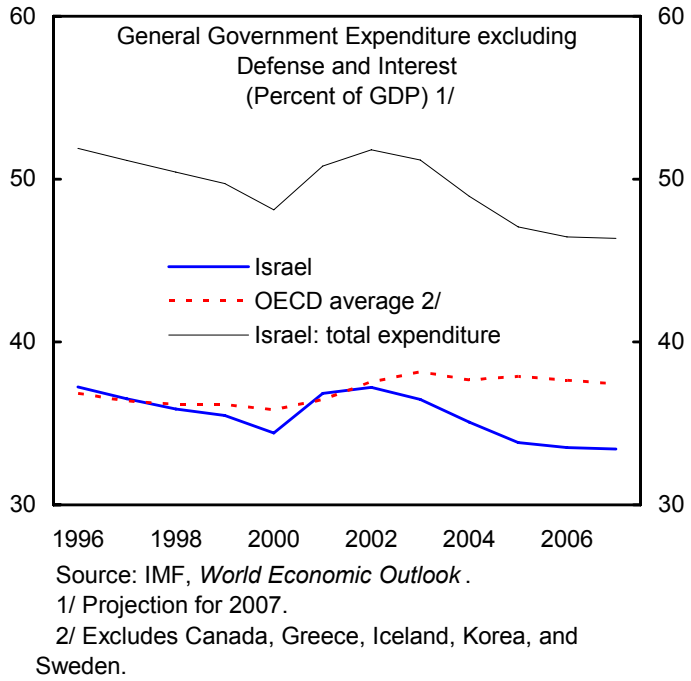

17. Staff reiterated the need for more fiscal transparency and better governance. To work well, rules need supporting fiscal institutions. For Israel, this means: ${ }^{9}$

- $\quad$ Better budgetary preparation and transparency. Budget documentation needs to include a multiyear scenario analysis of conjunctural and other risks for public finance objectives. Such an analysis could help communicate the vulnerability of the economy on account of the high public debt ratio.

\footnotetext{
${ }^{9}$ For details, see IMF Country Report No. 07/25, Chapter I.
} 
- $\quad$ Stronger fiscal governance, including an institutional set-up to help monitor independently the implementation of any new fiscal rule. Symptoms of creative accounting to meet the current expenditure rule are beginning to emerge, although they do not reach disconcerting proportions. Moreover, recent experience suggests that deviations from rules might be necessary for a variety of good reasons that are difficult to fully specify in advance. An independent and nonpartisan fiscal surveillance mechanism could help address these concerns.

- $\quad$ Improved long-term fiscal planning, including analytical work to better understand long-run challenges. The growth rate of the labor force, for example, may well decelerate from around $2 \frac{1}{2}$ percent per annum during 2000-05 to around $1 \frac{1}{2}$ percent during 2010-15. Some projections suggest that by 2050, only about 2-3 people in the workforce will support each retiree, down from more than 4 people today. These developments have fiscal implications that deserve discussion.

\section{The authorities agreed on the usefulness of risk analysis and better long-term} planning. BoI has already begun to publish a risk analysis after the submission of the budget to the Knesset, and to some extent performs the functions of a fiscal watchdog. The government also considered various macroeconomic scenarios when preparing the budget, although these had not been fleshed out in detail or published.

\section{E. Managing the Transformation of the Financial System}

19. Financial sector reforms are spurring rapid change. Under the July 2005 reforms, banks have been forced to divest themselves of mutual and provident fund management, to foster a less bank-centric financial system. Also, the abolition not too long ago of the obligation for institutional investors to hold fixed rate government bonds still reverberates. The same holds for the end of the differential tax treatment of holdings of foreign and domestic assets. New financial instruments have been introduced, including sale and repurchase agreements. Further significant measures are planned, including increasing the mobility of savings between different financial products and providers, the extension of (plain vanilla) securitization, and the introduction of money market funds. A new interministerial committee on capital markets has been established under the leadership of the Ministry of Finance to plan the next stages of development of the markets. 
Post-reform Changes in Control of Savings and Mutual Funds, 2003-06 1/

\begin{tabular}{lcccc}
\multicolumn{3}{c}{ (Percent) } & & \\
& $\begin{array}{c}\text { Five Largest } \\
\text { Banking } \\
\text { Groups }\end{array}$ & $\begin{array}{c}\text { Five Largest } \\
\text { Insurance } \\
\text { Groups }\end{array}$ & & $\begin{array}{c}\text { Other Financial } \\
\text { Institutions }\end{array}$ \\
\cline { 4 - 6 } & Total & Total & Total & $\begin{array}{c}\text { Of which: } \\
\text { Foreigners }\end{array}$ \\
\hline Total long-term savings & & & & \\
December, 2003 & 52 & 21 & 27 & 0 \\
December, 2004 & 50 & 28 & 22 & 0 \\
December, 2005 & 45 & 29 & 26 & 0 \\
December, 2006 & 19 & 47 & 35 & 7 \\
Mutual funds & & & & \\
December, 2004 & 84 & 2 & 13 & 0 \\
December, 2005 & 77 & 3 & 21 & 0 \\
December, 2006 & 1 & 41 & 58 & 33 \\
\hline
\end{tabular}

Source: Bank of Israel Annual Report, 2006.

1/ Resulting from pension fund reform and the adoption of the Bachar Committee proposals; estimates in percent of total assets.

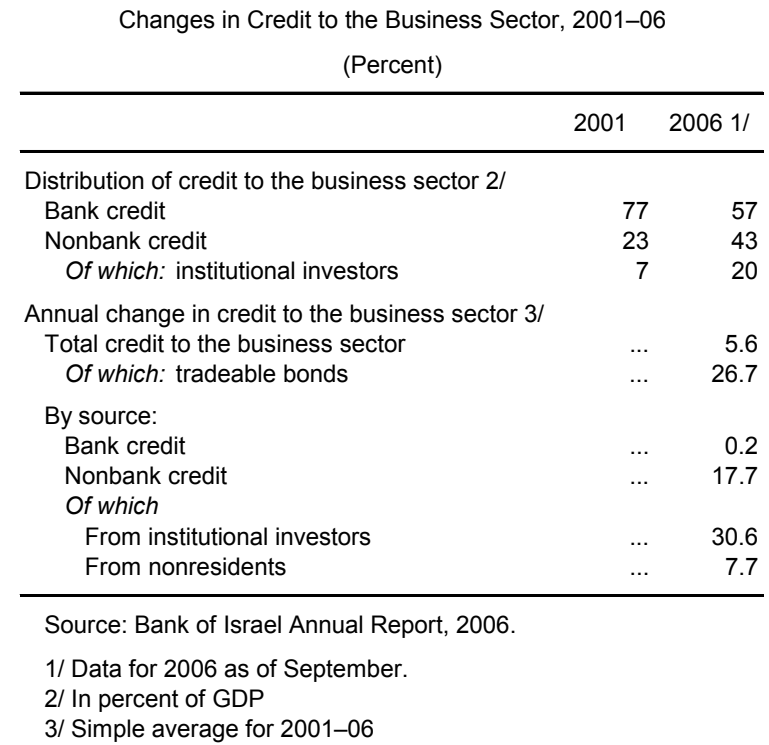

20. The shared view was that these changes entail increased risk in the short run but should make the economy more resilient in the long run. As a result of the reforms capital markets have flourished, the role of banks in funding the business sector has declined in relative terms, and that of institutional investors has increased. This is changing the nature of financial risks:

- $\quad$ Banks need to find new activities to substitute for old ones, while increasing their still comparatively low regulatory capital ratios and this is likely to lead them into riskier activities. Some, for example, are entering emerging markets. Accounting indicators, such as nonperforming loans and capital adequacy ratios, suggest a continuous improvement in banking sector soundness since 2002. Market indicators paint a somewhat different picture, suggesting that bank soundness, after a substantial 
improvement between 2003 and 2005, may have been retreating in 2006 and 2007. This may reflect reform-related drops in franchise values as well as uncertainties over the long run impact of global credit conditions. ${ }^{10}$ However, stress tests based on publicly available data suggest improving system robustness, with credit risk as the main source of risk (Box 2). ${ }^{11}$
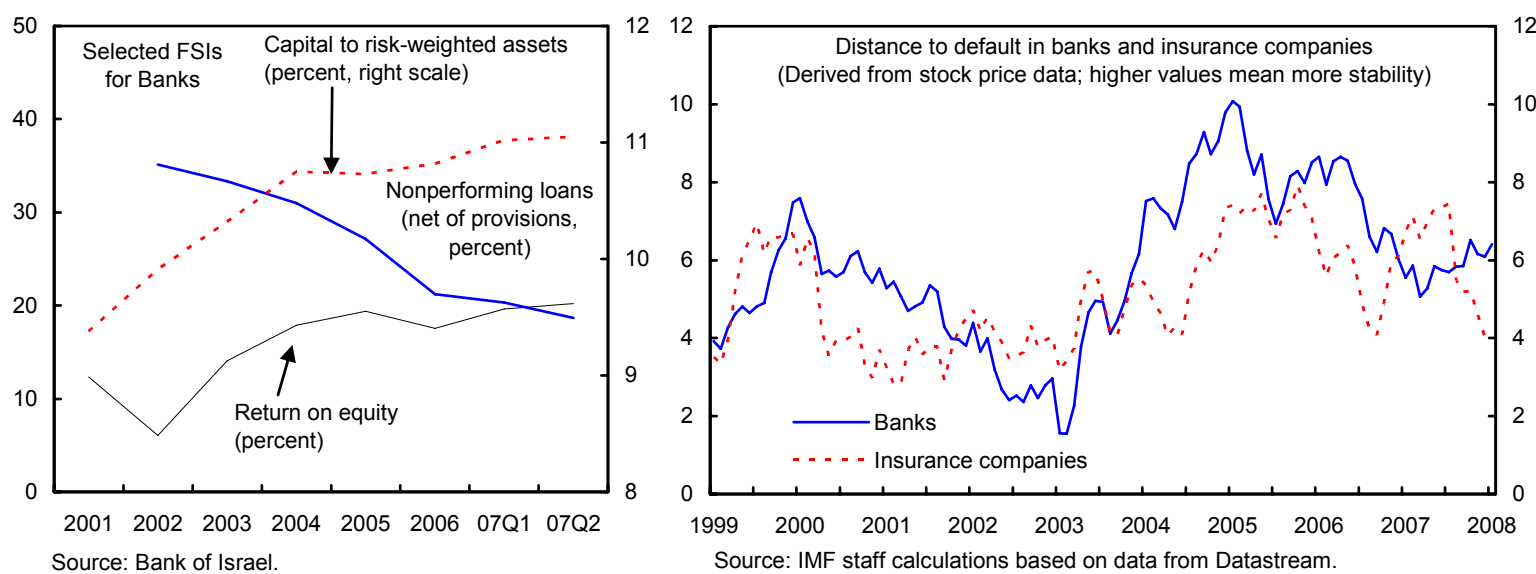

- $\quad$ Managed funds are rapidly increasing their holdings of assets with higher risk and this requires a commensurate improvement in risk management capacities, even if the risks are ultimately largely borne by households. During 2002-06, the public's holdings of shares and corporate bonds rose from 14 to 32 percent of all assets, mainly at the expense of cash, deposits and government bonds. Concurrently, the end of discriminatory taxation of investments abroad triggered sizable capital outflows.

- Insurers' business profiles are more diversified as a result of the recent reforms but this is coming with new risks. The types of permissible activities have been relaxed. Most significantly, insurance companies have acquired the largest share of the fund management businesses which banks have been required to sell. As a result, insurance firms and their affiliates are assuming new or enhanced risks, including credit risk, with which they have less experience.

- $\quad$ The changes in markets are temporarily stretching the resources of the authorities both on the regulatory and the supervisory front.

\footnotetext{
${ }^{10}$ Stock market indicators for insurance companies have weakened recently as a result of the latest market turbulence, although not in a major way.

${ }^{11}$ See also Selected Issues paper, Chapter II.
} 


\section{Box 2. Banking Sector Stress Tests}

- $\quad$ Staff performed stress tests of the banking sector to assess banks' resilience to potential shocks to credit risk, interest rate, exchange rate, liquidity, and equity price risk; and to macroeconomic scenarios involving combinations of these shocks.

- The main result of the tests is that resilience of the banking system has improved. This reflects a combination of increasing buffers (improving capitalization and profitability) with generally decreasing exposures.

- $\quad$ The tests confirm credit risk as the main source of risk. Banks' exposures to direct interest rate risk are limited, as most of banks' loan books are in floating rates, and the duration of banks' trading portfolios is relatively short. Banks also have low direct exchange rate risk, reflecting their relatively low foreign exchange positions, and their exposures to equity risk are moderate. Banks are liquid at present, which was reflected in positive results of tests of the impact of sudden withdrawals.

- $\quad$ The staff's tests were based on publicly available data. The staff encouraged the authorities to start carrying out regular stress tests using supervisory data.
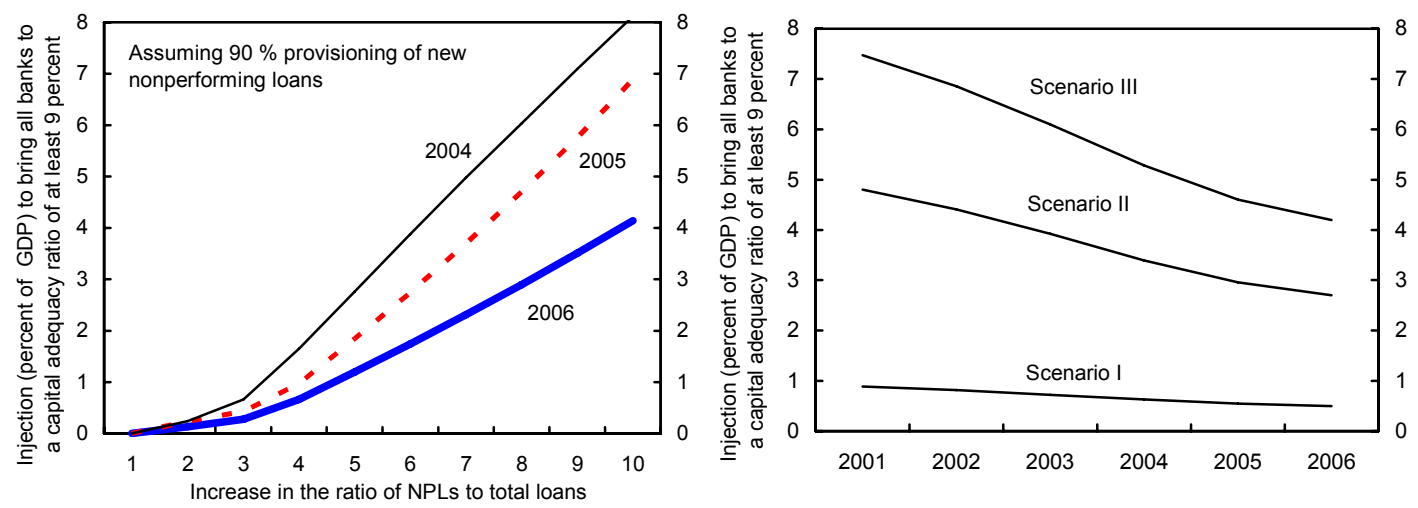

Sources: Staff calculations based on data from annual reports; BankScope; and Datastream.

Notes: Scenario I was parametrized using the last major recession in Israel (2001-02) as a reference point; Scenario II is a more stresssful version of Scenario I; and Scenario III assumes shocks to GDP, exchange rate, and interest rate equal to average of those in a world-wide sample of 17 recent financial crises (see the accompanying Selected Issues Paper).

\section{There was widespread agreement on the need to develop and implement} regulation to keep pace with changing risks and new international standards. The mission welcomed the progress being made with implementation of Basel II for banks, more risk-based approaches to supervision of banks, and improvements in disclosure and 
enforcement of standards. ${ }^{12}$ Regulators have recently agreed on a Memorandum of Understanding to improve exchanges of information and practical cooperation on initiatives of common interest.

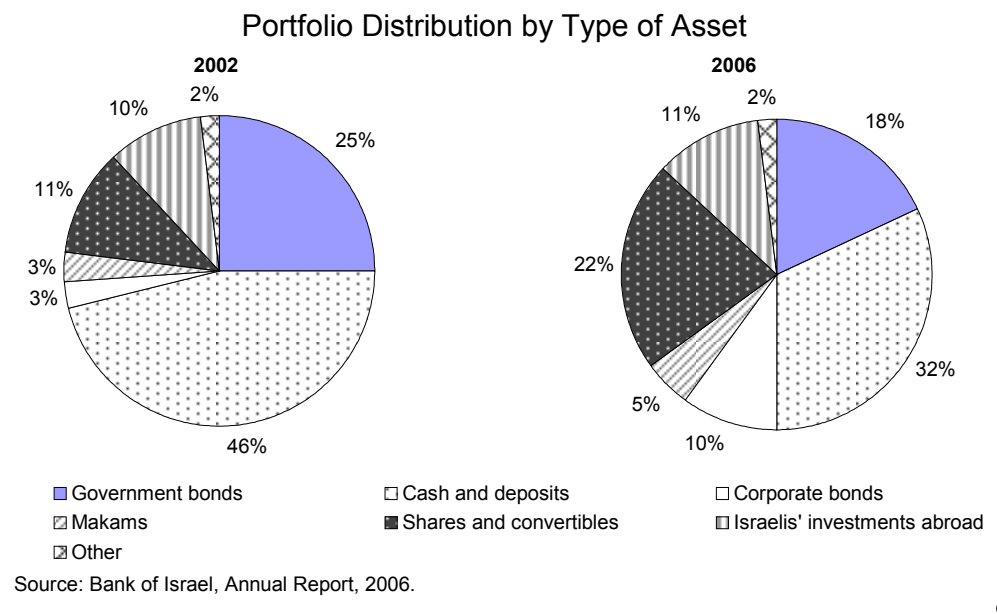

Share of Institutional Investors' Asset Portfolios Invested Abroad, in Shares, and Tradeable Private and Government Bonds, 2004-06 (Percent)

\begin{tabular}{|c|c|c|c|c|c|c|c|c|c|c|}
\hline & \multicolumn{2}{|c|}{ Investments Abroad 1/ } & \multicolumn{2}{|c|}{ Shares 2/ } & \multicolumn{2}{|c|}{ Private Bonds 2/ } & \multicolumn{2}{|c|}{ Government Bonds 2/ } & \multicolumn{2}{|c|}{ Other Assets $3 /$} \\
\hline & 2004 & 2006 & 2004 & 2006 & 2004 & 2006 & 2004 & 2006 & 2004 & 2006 \\
\hline All institutional investors & 4.5 & 9.6 & 10.3 & 12.7 & 17.0 & 18.7 & 52.6 & 42.7 & 22.0 & 16.3 \\
\hline Provident and severance pay funds & 3.0 & 8.9 & 16.6 & 18.6 & 17.5 & 27.6 & 41.3 & 29.2 & 21.6 & 15.7 \\
\hline Pension funds $4 /$ & 0.6 & 5.8 & 7.8 & 9.2 & 10.0 & 18.2 & 71.3 & 53.4 & 10.4 & 13.3 \\
\hline Mutual funds & 13.0 & 17.9 & 11.3 & 14.2 & 3.9 & 13.6 & 27.8 & 29.9 & 44.0 & 24.4 \\
\hline Insurance plans 5/ & 5.6 & 9.5 & 7.7 & 10.6 & 10.3 & 11.7 & 53.1 & 43.5 & 23.4 & 21.4 \\
\hline
\end{tabular}

Source: Bank of Israel Annual Report, 2006

1/ Including investments in Israeli securities traded abroad, foreign securities, deposits abroad and mutual funds. Does not include investments in ETFs traded in Tel Aviv that track indexes abroad.

2/ Tradeable and non-tradeable assets

3/ Makams, indexed and unindexed deposits, loans, mutual fund units, property rights, futures, mortgage portfolios and other assets.

4/ Including the Central Pension Provident Fund.

$5 /$ Investment assets for life-insurance schemes.

\section{The Ministry of Finance is reforming insurance regulation extensively in} response to the development of insurance companies' business. The inadequacy of existing solvency requirements has been recognized and proposals made to strengthen the regime in the near future. Efforts are being made to improve the quality of the risk management and controls of insurance companies. Risk-based supervision is being developed.

\section{Regulators are seeking to improve the financial strength of banks and insurance companies further to prepare for a possible economic downturn and coming regulatory}

\footnotetext{
${ }^{12}$ Progress has also been made on AML/CFT. A ROSC summarizing the findings of a Moneyval assessment will be prepared during 2008. As a related matter, the authorities remain committed to ensuring a continuing clearing function for West Bank/Gaza banks; however, there are concerns about the vulnerability for potential misuse of the Israeli financial system that are in the process of being addressed.
} 
change. The Bank of Israel has asked banks to increase capital ratios further in advance of the implementation of Basel II, the impact of which on bank capital adequacy remains unclear. Insurance companies are being asked to restrict the payment of dividends to no more than 50 percent of income pending finalization of the new solvency requirements.

\section{The mission welcomed the improvements made to date but pointed to the challenges ahead. ${ }^{13}$ Discussions covered five issues:}

- Of critical importance is the ability of regulators to build the expertise necessary to support the more complex regulatory system now being put in place. This requires greater recruitment flexibility and competitive pay scales, in line with the practice in many advanced countries. The authorities explained that they had hired industry experts on a consultant basis but agreed that this was not optimal.

- $\quad$ There is a risk that the rapid pace of regulatory change will prove inconsistent with high-quality implementation. Additionally, all regulatory initiatives carry costs to consumers, firms, and regulators themselves. This calls for submitting major new initiatives to cost-benefit analysis. The authorities agreed but expressed concern about the resource implications. Staff explained that some rebalancing from the very rules-based approach to a more principles-based approach by the authorities could be helpful in alleviating resource constraints and also came with other advantages.

- $\quad$ As increased competition brings more risk, there is a need for a strong capacity to manage and resolve financial stress if and when it emerges. In this regard, the mission welcomed the recent Memorandum of Understanding among the supervisors, which includes provisions on crisis management. However, staff argued for further work, such as exercises that test responses to crisis scenarios, to identify remaining gaps.

- In line with good international practice, the insurance supervisor needs independence to set solvency standards; enforce managerial changes in companies and resolve failing institutions, as necessary; and powers to perform groupwide supervision. The authorities agreed, but they thought that the legal process to achieve this was complex and lengthy. Accordingly, they wanted to await a clearer vision of how to adapt the structure of supervision to markets before proceeding on this front.

\footnotetext{
${ }^{13}$ See Selected Issues Paper, Chapter III.
} 


\section{F. Social Policy}

25. Social policy remains a priority for the government, given concerns about inequality. The government set two key medium-run social targets: (i) raising the employment rate at ages $25-64$ by about 3 percentage points to 71.7 percent by 2010 ; and (ii) increasing the income of the poorest fifth of the population by 10 percent more than per capita GDP. Key measures during 2007 included the adoption of (presently on a pilot basis) an Earned Income Tax Credit and the phased introduction of a compulsory employer-provided pension pillar, which was welcomed by both employer and worker representatives.

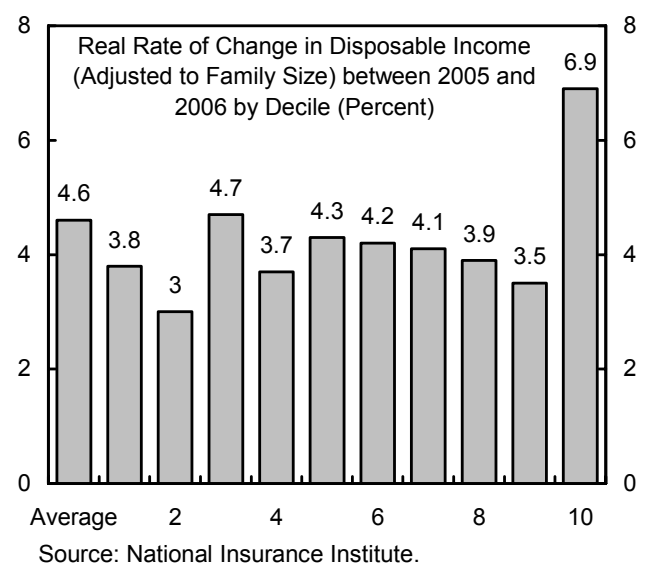

\section{Staff ApPraisal}

26. The economy is performing exceptionally well but still high public indebtedness calls for the continuation of the strong economic policies. While sound policies have been central to the strong performance, so has unprecedented global growth. Moreover, with the public debt today not much lower than before the latest recession and the country still highly vulnerable to economic shocks, debt reduction remains the key macroeconomic policy challenge. Welcome improvements to the financial sector framework also need to be carried forward to enhance the economy's robustness.

\section{Economic activity is likely to remain strong, even if less buoyant than in recent} years, and domestic inflationary pressure elevated. Domestic preconditions for continued output growth remain in place, while external conditions are becoming less supportive. Given continued solid growth and growing capacity constraints, inflationary pressures would probably mount. Higher interest rates are thus probably needed for inflation to stay on target over the medium run but external downside risks and heightened risk premia argue for caution in raising rates.

28. Monetary policy has successfully stabilized inflation expectations, but policy and communication challenges remain. These stem largely from the high pass-through of the NIS/US \$ exchange rate to domestic prices. The publication of inflation reports on a quarterly rather than semi-annual basis and the release of model-based inflation and interest rate forecasts are welcome. But greater clarity is needed about the role of these forecasts in BoI's decision making, the relationship between these forecasts and those for other macroeconomic variables, and about the policy horizon. In addition, swift adoption of the draft BoI law is particularly important because it would strengthen the economy's institutional foundation. 
29. The recent positive fiscal performance needs to be carried forward into 2008 to cement its many benefits, including those related to improved international credibility. The central government budget needs to be kept close to balance, given that good times are expected to prevail and the economy's vulnerability to shocks on account of the high debt ratio needs to be lowered. It is thus appropriate that the budgeted 1.6 percent of GDP central government deficit is a ceiling and not a target. Maintaining a sound fiscal policy stance demands strict compliance with the 1.7 percent expenditure growth ceiling, tight budget execution, and the allocation of any revenue overperformance to debt reduction.

30. The government's intention to stick with a rules-based approach to fiscal policy, solidly anchored in longer-run objectives, is welcome. The main objective of a new rule should be to achieve a 60 percent debt-to-GDP ratio by 2015. This ratio is considered an upper limit in many less exposed advanced economies and it can be achieved without an appreciable tightening in fiscal policy. Furthermore, debt reduction should be given precedence over tax cuts, although there is scope to simplify the relatively complex tax system, including through cutting tax exemptions.

\section{Enhanced fiscal transparency and governance are essential to improve the} quality of policy making. Budget documentation needs to include a multiyear scenario analysis of risks for public finance objectives, and a long-term fiscal sustainability analysis, which can help the public appreciate the importance of rapid debt reduction. The governance of the fiscal framework should be further strengthened by instituting independent, nonpartisan fiscal evaluation.

32. The ambitious reforms of recent years are fostering the development of a more diversified financial system but they also raise new risks. With the economic expansion, financial soundness indicators have been improving, and risks of major losses in financial institutions appear low, although regulatory capital and solvency levels remain lower than in many advanced economies. In the meantime, the reforms have unleashed dramatic changes that have increased the complexity of the financial system. This raises the importance of high-quality prudential policies and practices, close collaboration among regulators, and ensuring that reporting standards for financial institutions do not deviate unnecessarily from international norms.

\section{While much work to adapt the prudential framework and financial} infrastructure is ongoing, the challenges ahead are still major, and regulators' resources are not commensurate. In particular, the regulators are moving to increase capital and solvency levels, and are at an early stage of introducing risk-based supervision approaches. However, regulators need to be able to build the expertise necessary to support a more complex regulatory system, which in turn requires greater recruitment flexibility and competitive pay scales. Also, the authorities need to ensure consistency between the pace of regulatory change and high-quality implementation, and achieve the right balance between principles-based and rules-based approaches to supervision. They need to strengthen their 
capacity to manage and resolve financial stress. Finally, the insurance supervisor needs to be granted formal independence and broader powers, in line with international standards.

34. Israel has subscribed to the Special Data Dissemination Standards and its macroeconomic statistical system is generally adequate for Fund surveillance.

35. It is recommended that the next Article IV consultation be held on the standard 12month cycle. 
Figure 1. Israel: The Long View, 1996-2007 1/

(Percent, unless otherwise indicated)

Israel's growth performance has been solid as of late...
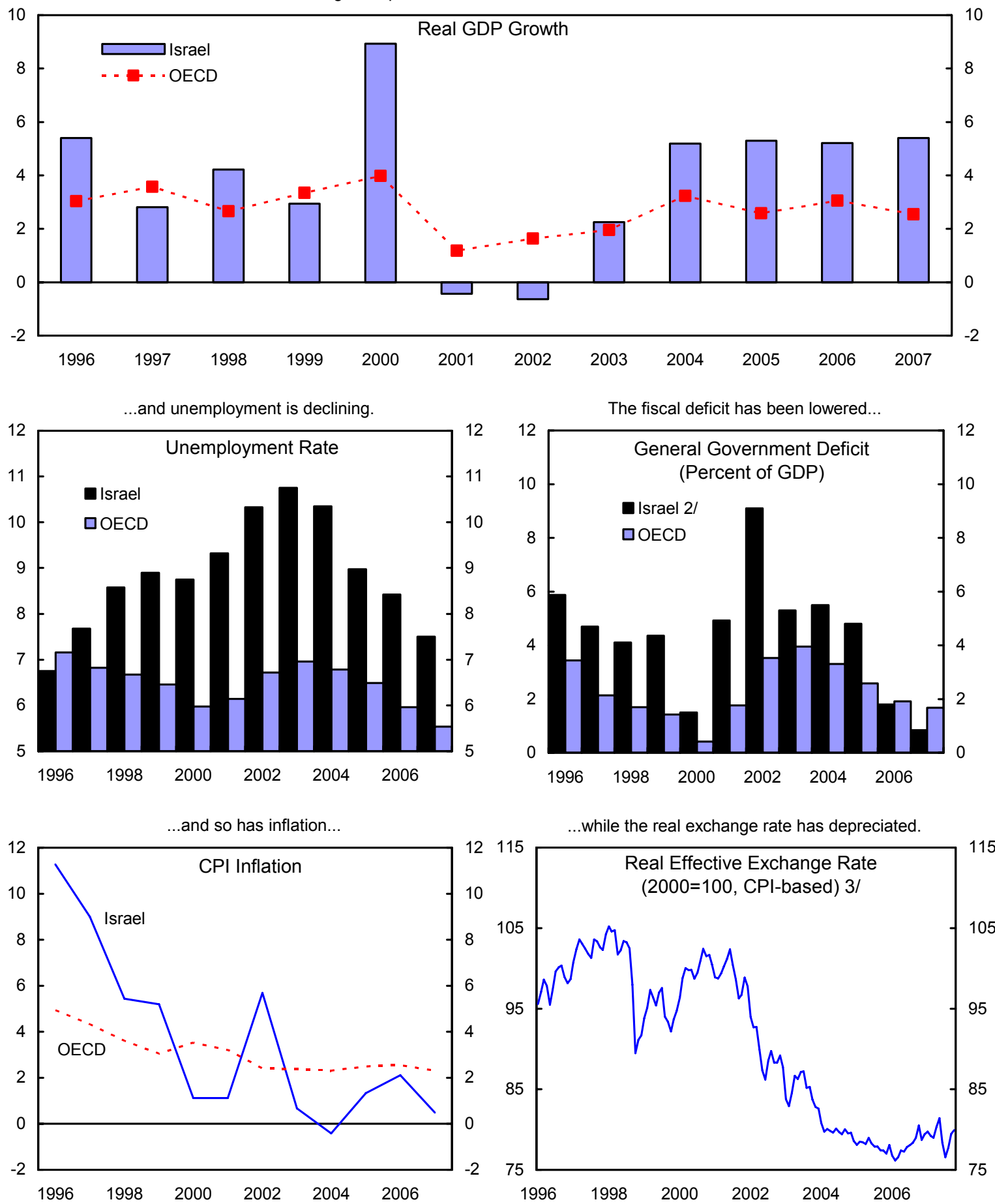

Sources: IMF, World Economic Outlook; and IMF, Information Notice System.

1/ Projections for 2007.

2/ From 1999 onward, international definition, accrual basis.

3/ Data for 2007 as of October. 
Figure 2. Israel: External Indicators, 2001-07
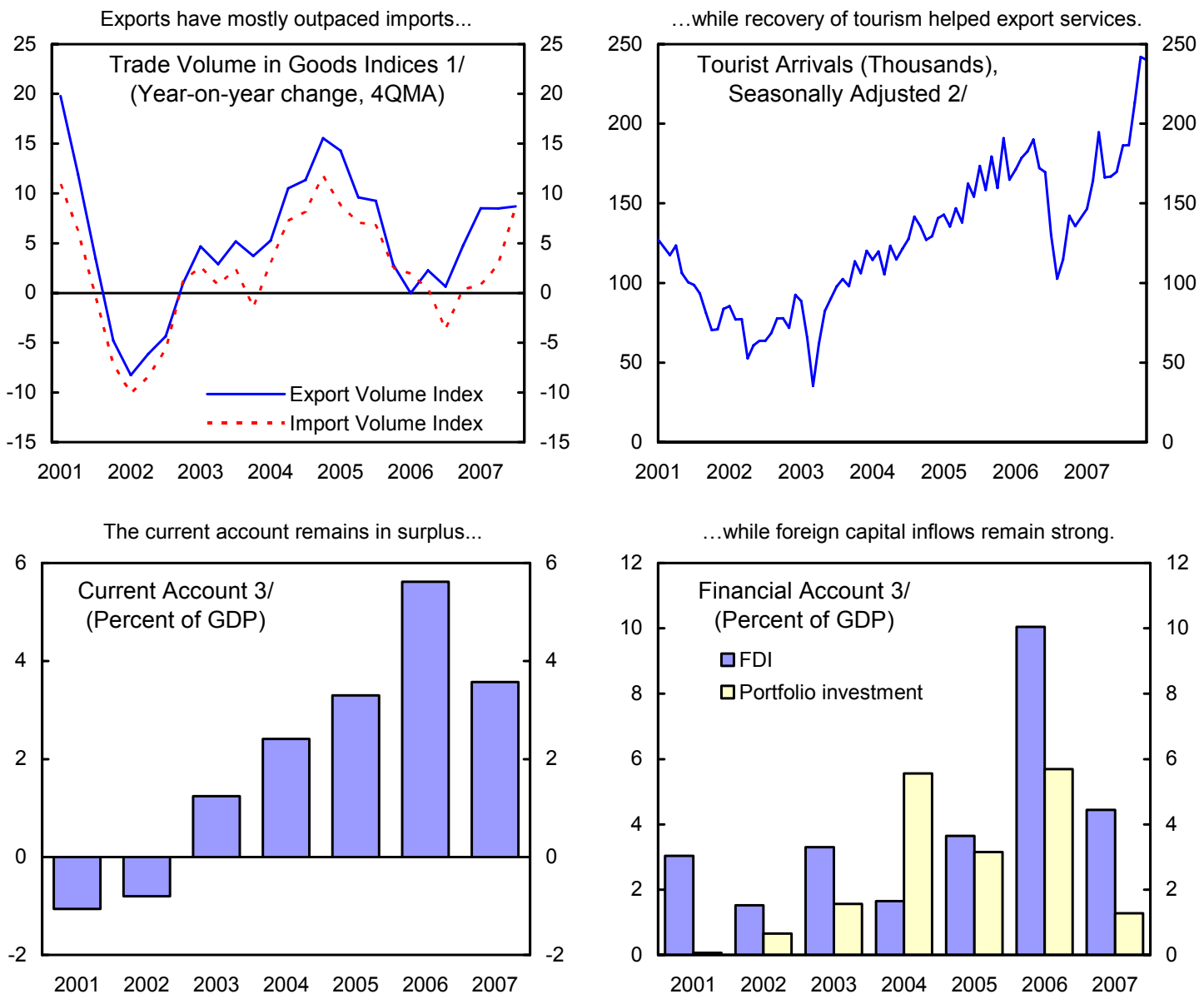

Competitiveness gains have been sustained...

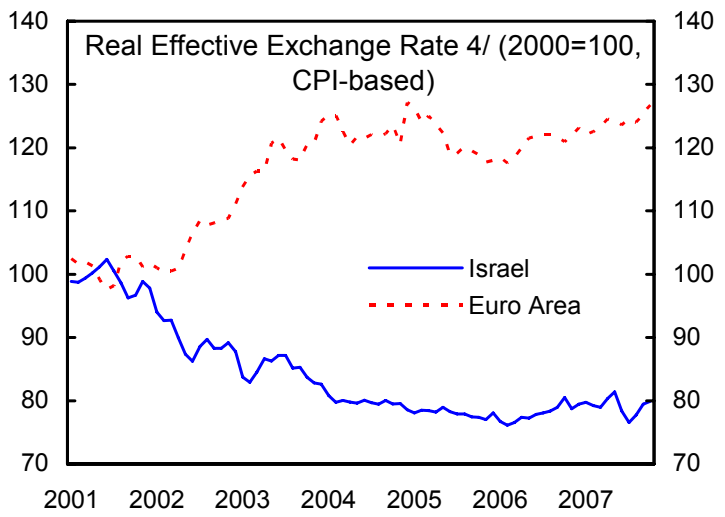

...notwithstanding recent NIS appreication against USD.

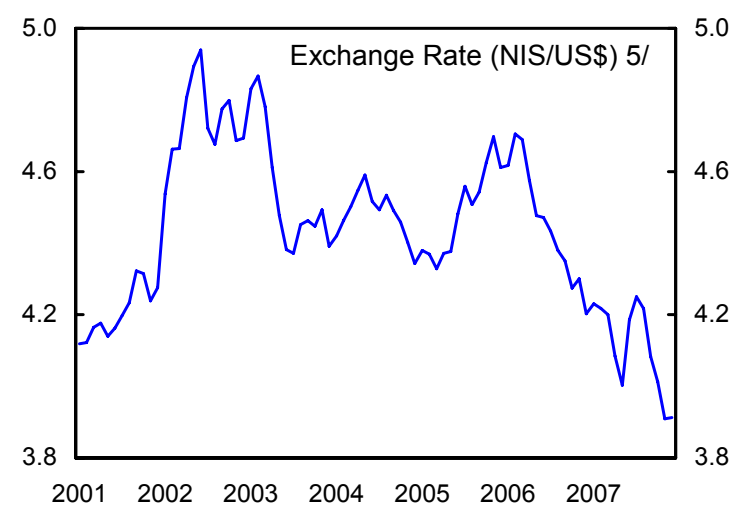

Sources: Central Bureau of Statistics; Bank of Israel; and IMF staff projections.

$1 /$ Inclusive of goods and services; data for 2007 as of September.

2/ Data for 2007 as of November.

3/ Projection for 2007.

4/ A decrease represents depreciation. Data for 2007 as of October.

5/ Data for 2007 as of December. 
Figure 3. Israel: Selected Monetary and Financial Indicators, 2006-07
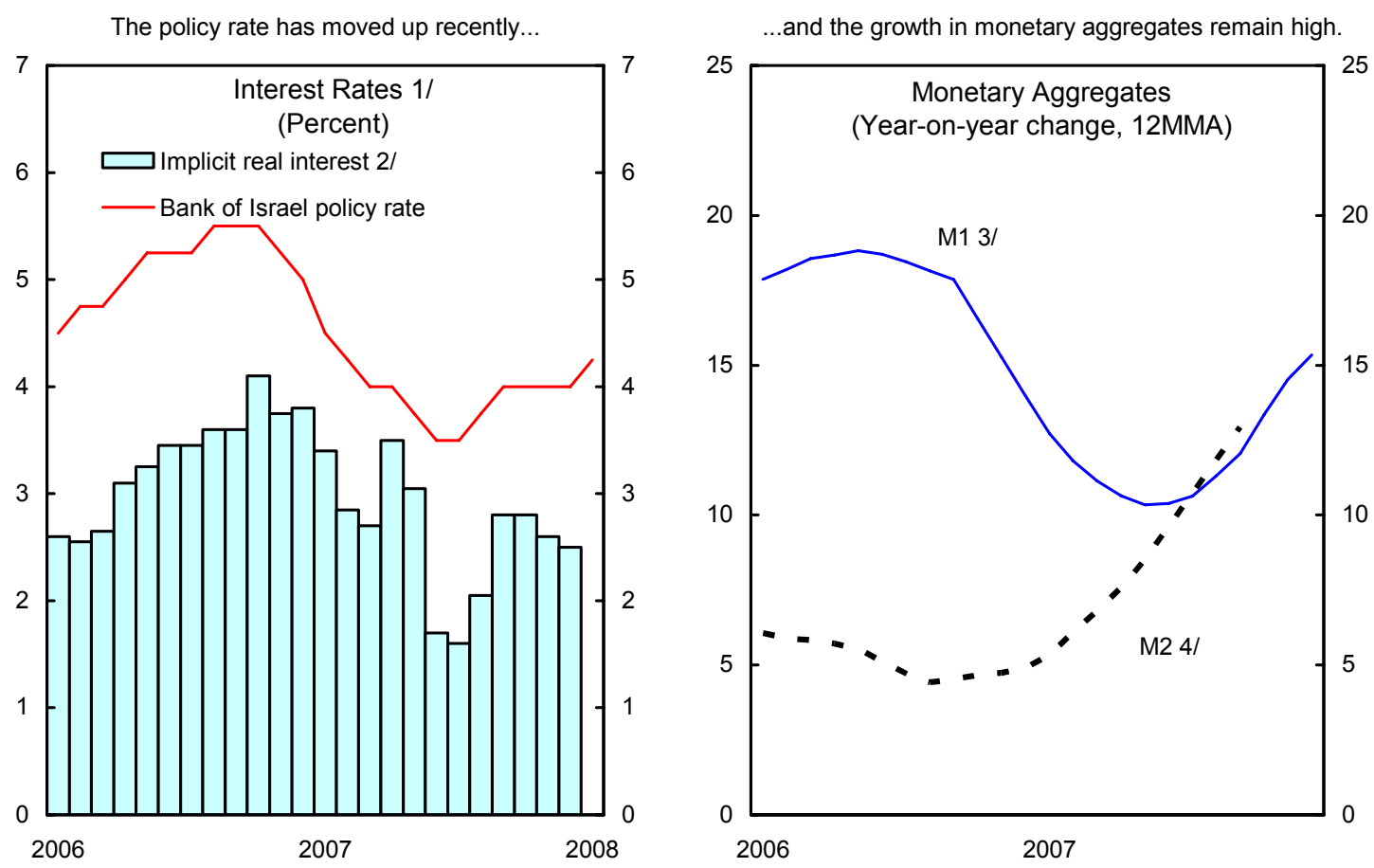

The risk premium rose in 2007 , albeit moderately...
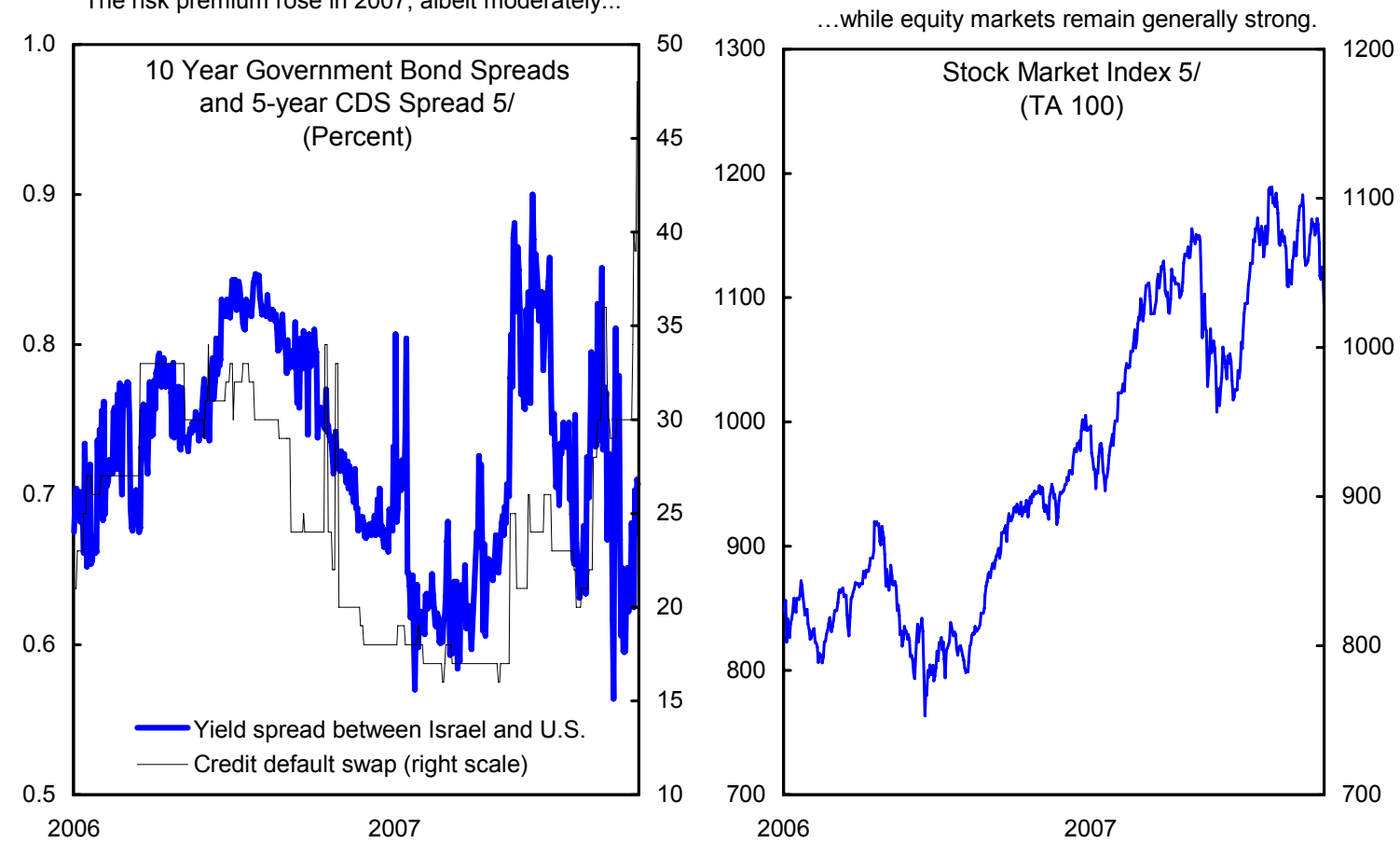

Sources: Bank of Israel; IMF, International Financial Statistics; and Bloomberg.

1/ Data for 2008 as of January.

2/ Defined as the Bank of Israel policy rate minus inflation expectations. Data for 2007 as of December.

3/ Data for 2007 as of December.

4/ Data for 2007 as of October.

5/ Data for 2008 as of January 3. 
Figure 4. Israel: Labor Market, 1987-2008
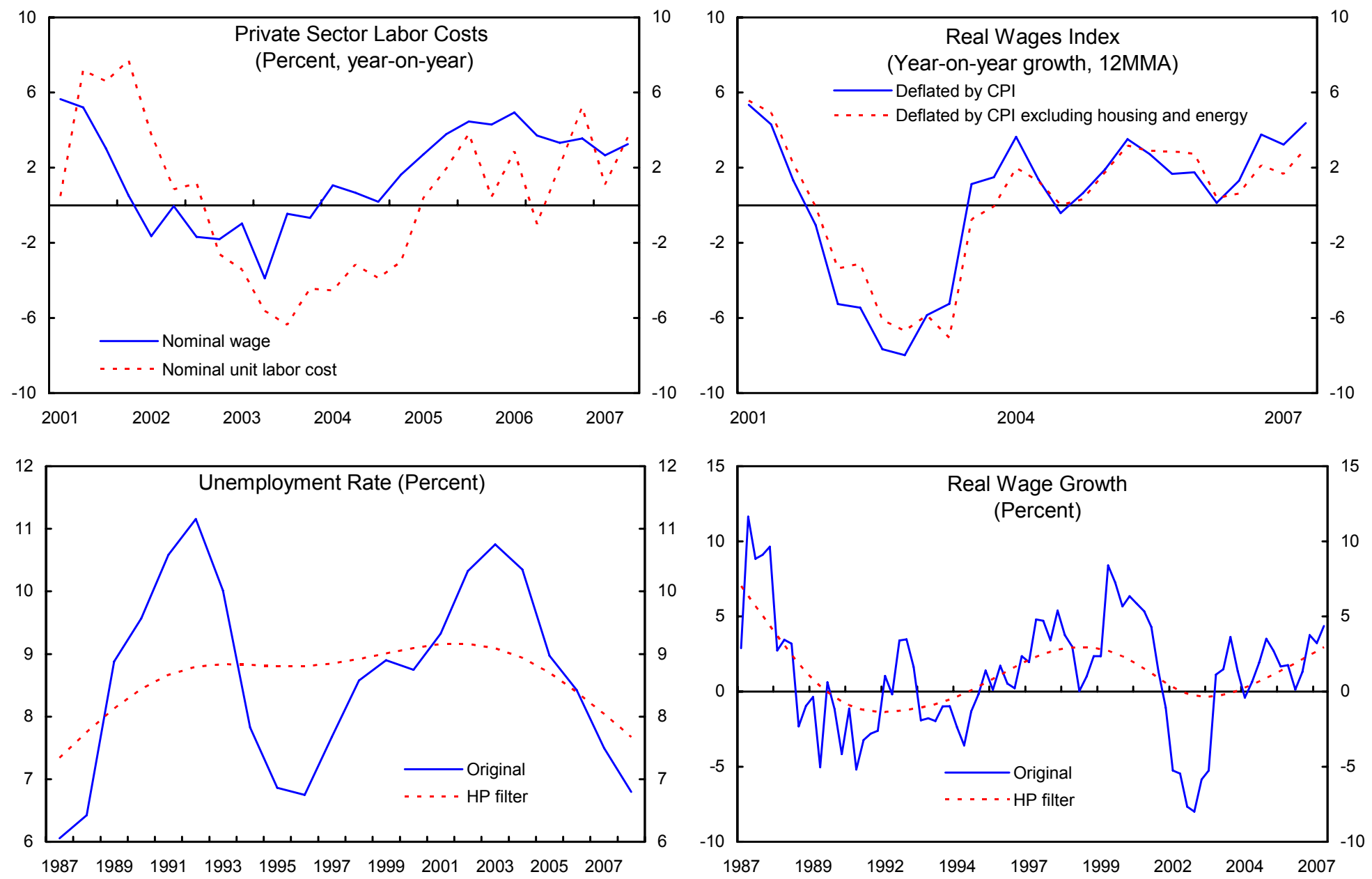

Sources: Bank of Israel; Central Bureau of Statistics; and IMF staff estimates and calculations. 
Figure 5. Israel: External Debt Sustainability: Bound Tests 1/ (External debt in percent of GDP)
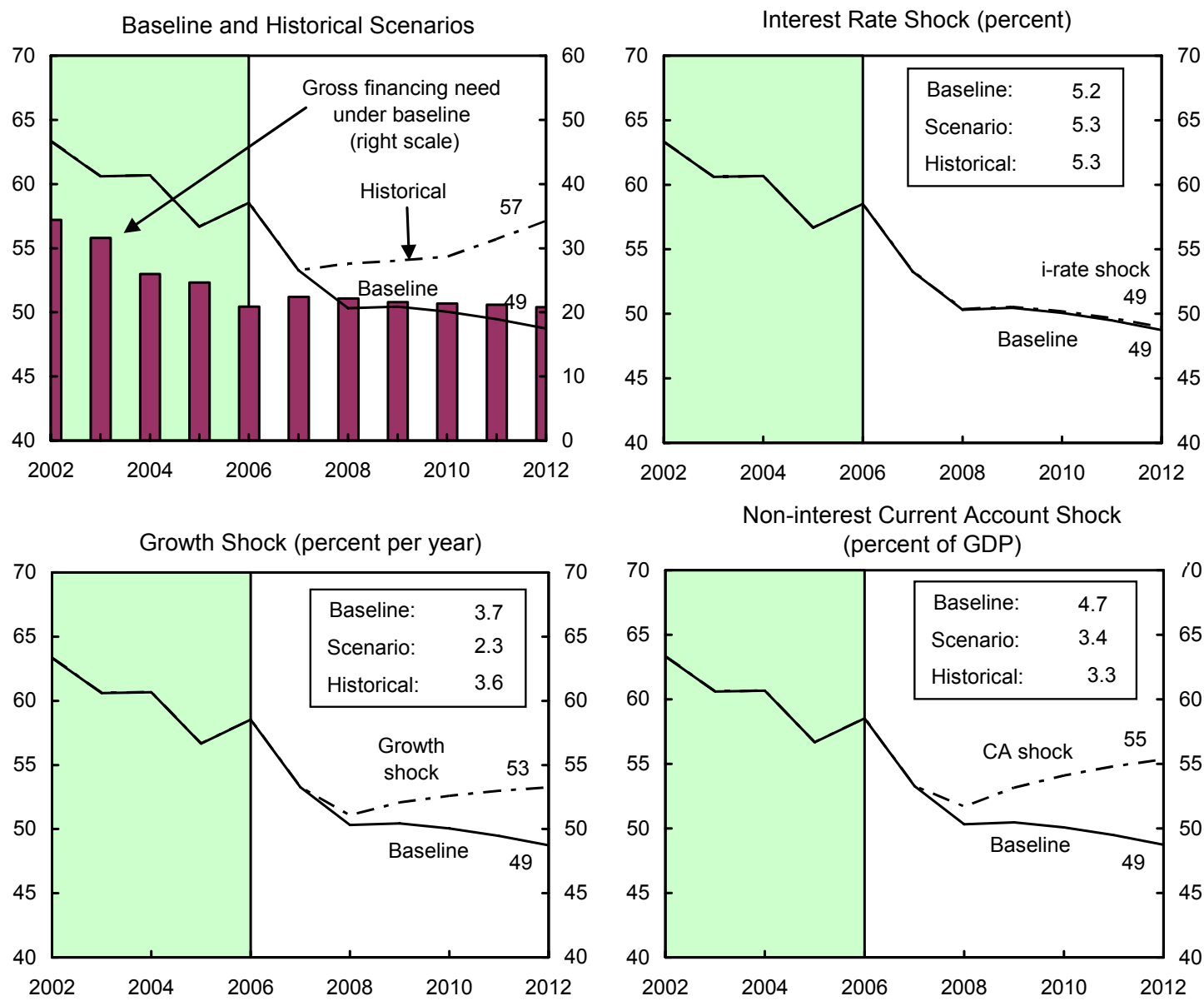

Combined Shock 2/
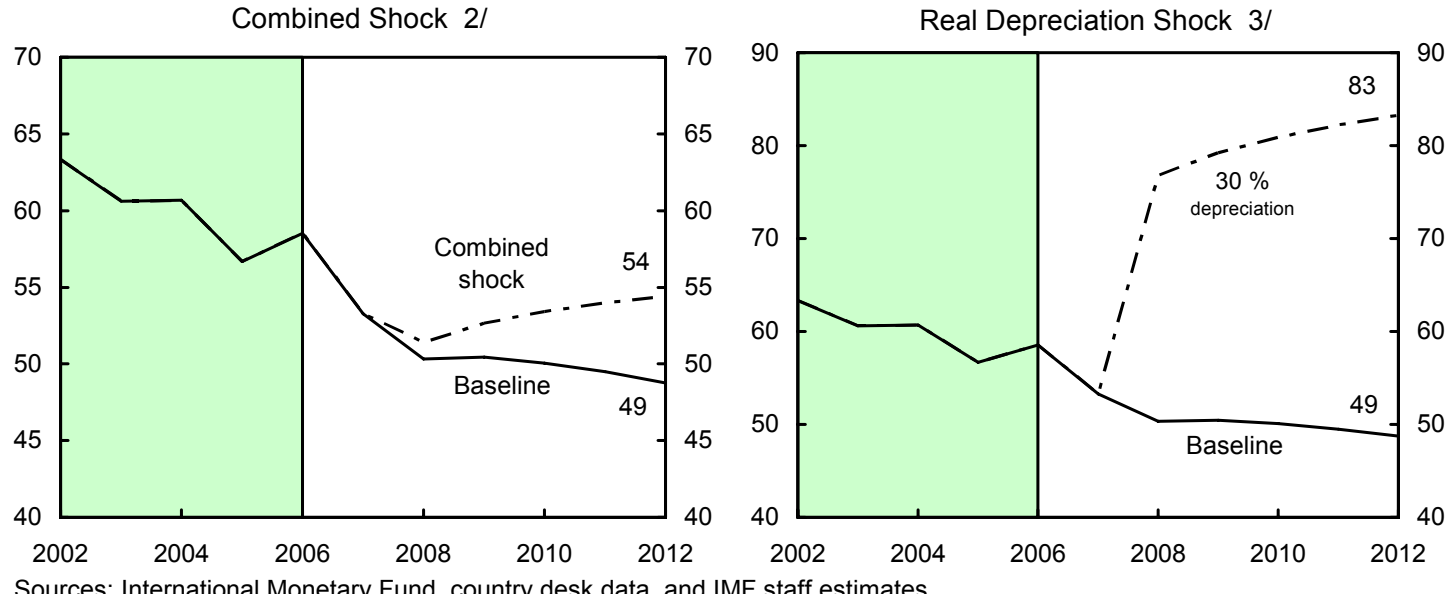

Sources: International Monetary Fund, country desk data, and IMF staff estimates.

1/ Shaded areas represent actual data. Individual shocks are permanent one-half standard deviation shocks. Figures in the boxes represent average projections for the respective variables in the baseline and scenario being presented. Ten-year historical average for the variable is also shown.

2/ Permanent 1/4 standard deviation shocks applied to real interest rate, growth rate, and current account balance.

3/ One-time real depreciation of 30 percent occurs in 2008. 
Figure 6. Israel: Recent Economic Indicators, 2001-07

(Percent, unless otherwise indicated)

Output expansion has been strong...
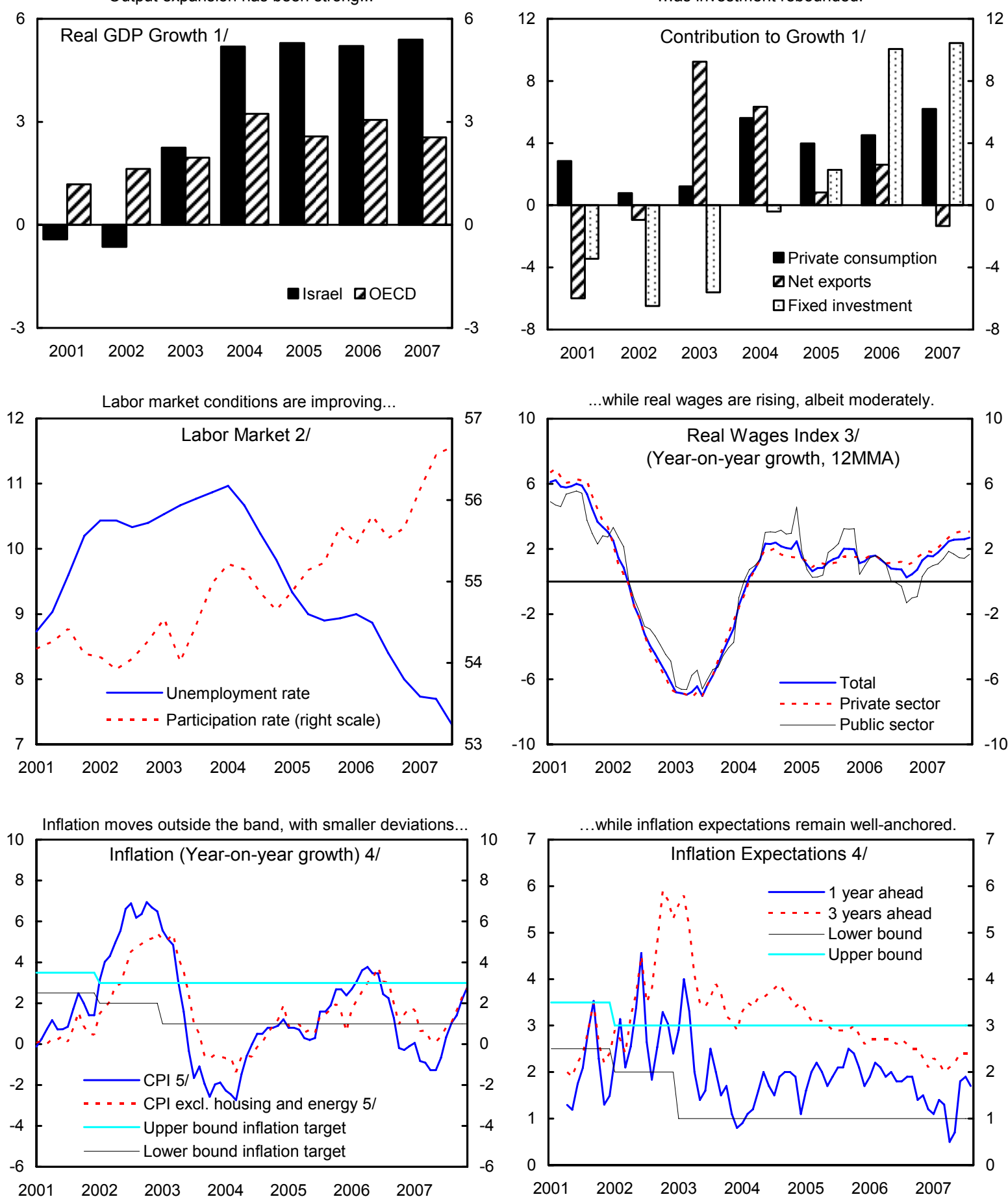
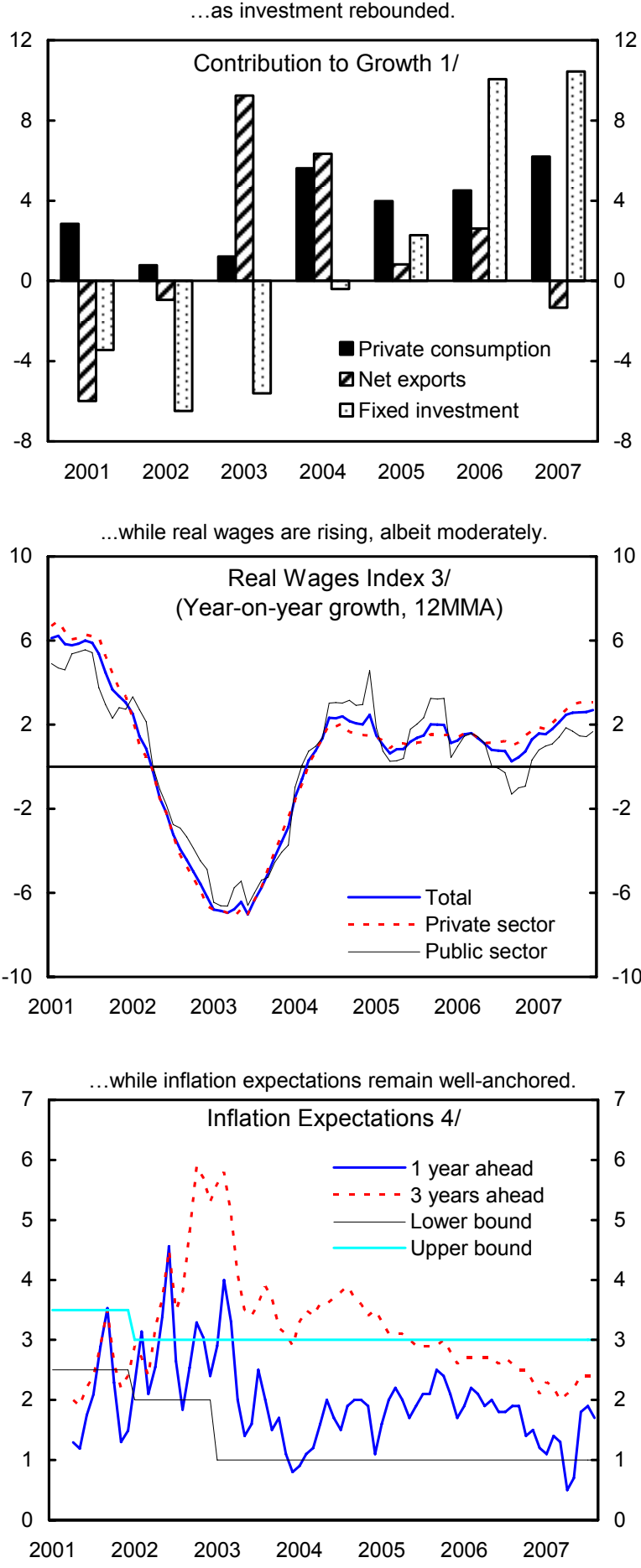

Sources: Central Bureau of Statistics; Bank of Israel; IMF, World Economic Outlook; and IMF staff calculations.

1/ Projection for 2007.

2/ Seasonally adjusted; data for 2007 as of September.

3/ Data for 2007 as of September

4/ Data for 2007 as of November.

5/ Percentage change from the corresponding period one year earlier. 
Figure 7. Israel: Public Debt Sustainability: Bound Tests 1/ (Public debt in percent of GDP)

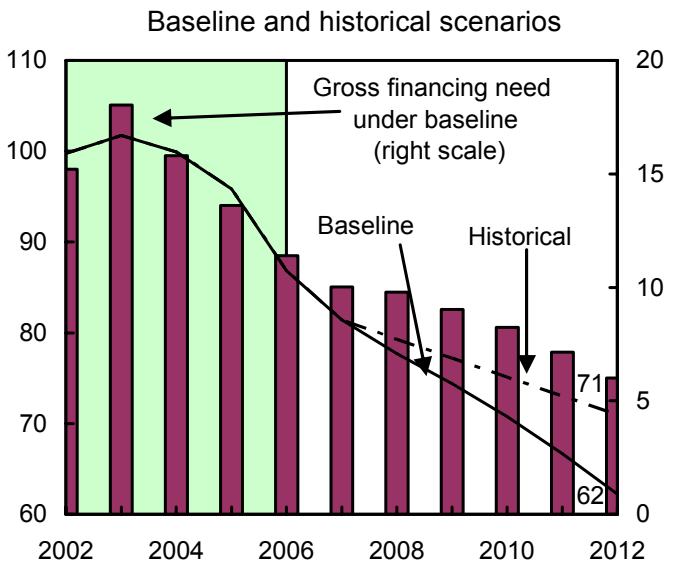

Growth shock (percent per year)

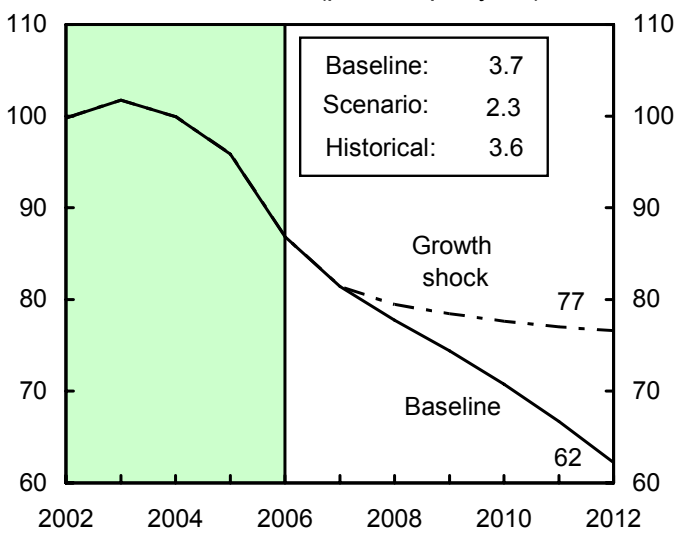

Combined shock 2/

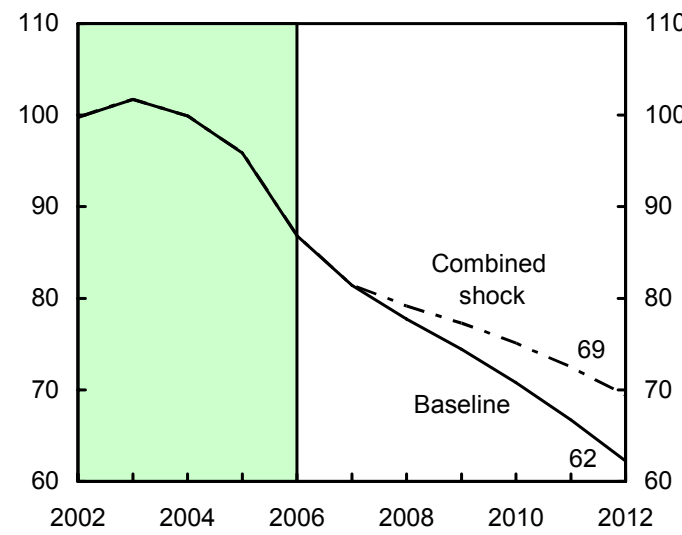

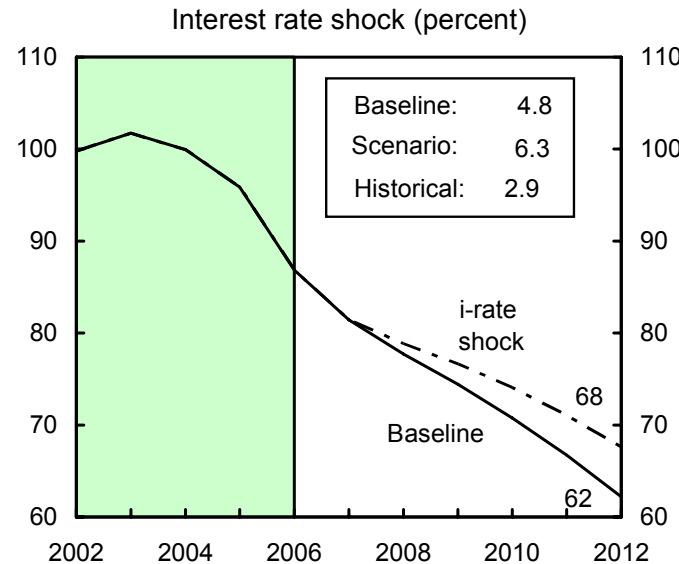

Primary balance shock (percent of GDP) and no policy change scenario (constant primary balance)

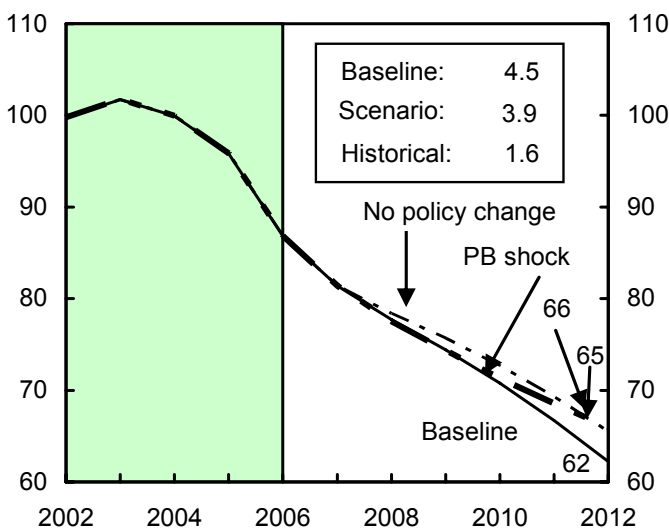

Real depreciation and contingent liabilities shocks 3/

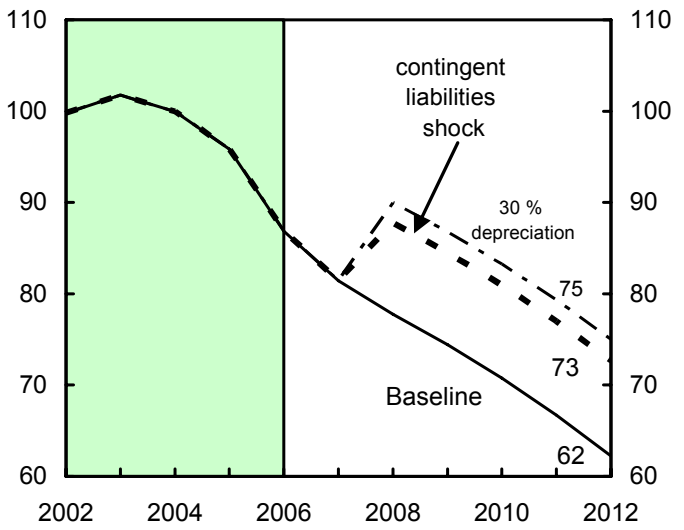

Sources: International Monetary Fund, country desk data, and IMF staff estimates.

1/ Shaded areas represent actual data. Individual shocks are permanent one-half standard deviation shocks. Figures in the boxes represent average projections for the respective variables in the baseline and scenario being presented. Ten-year historical average for the variable is also shown.

2/ Permanent $1 / 4$ standard deviation shocks applied to real interest rate, growth rate, and primary balance.

3/ One-time real depreciation of 30 percent and 10 percent of GDP shock to contingent liabilities occur in 2008, with real depreciation defined as nominal depreciation (measured by percentage fall in dollar value of local currency) minus domestic inflation (based on GDP deflator). 
Figure 8. Israel: Fiscal Developments, 2001-07 1/

(Percent of GDP)
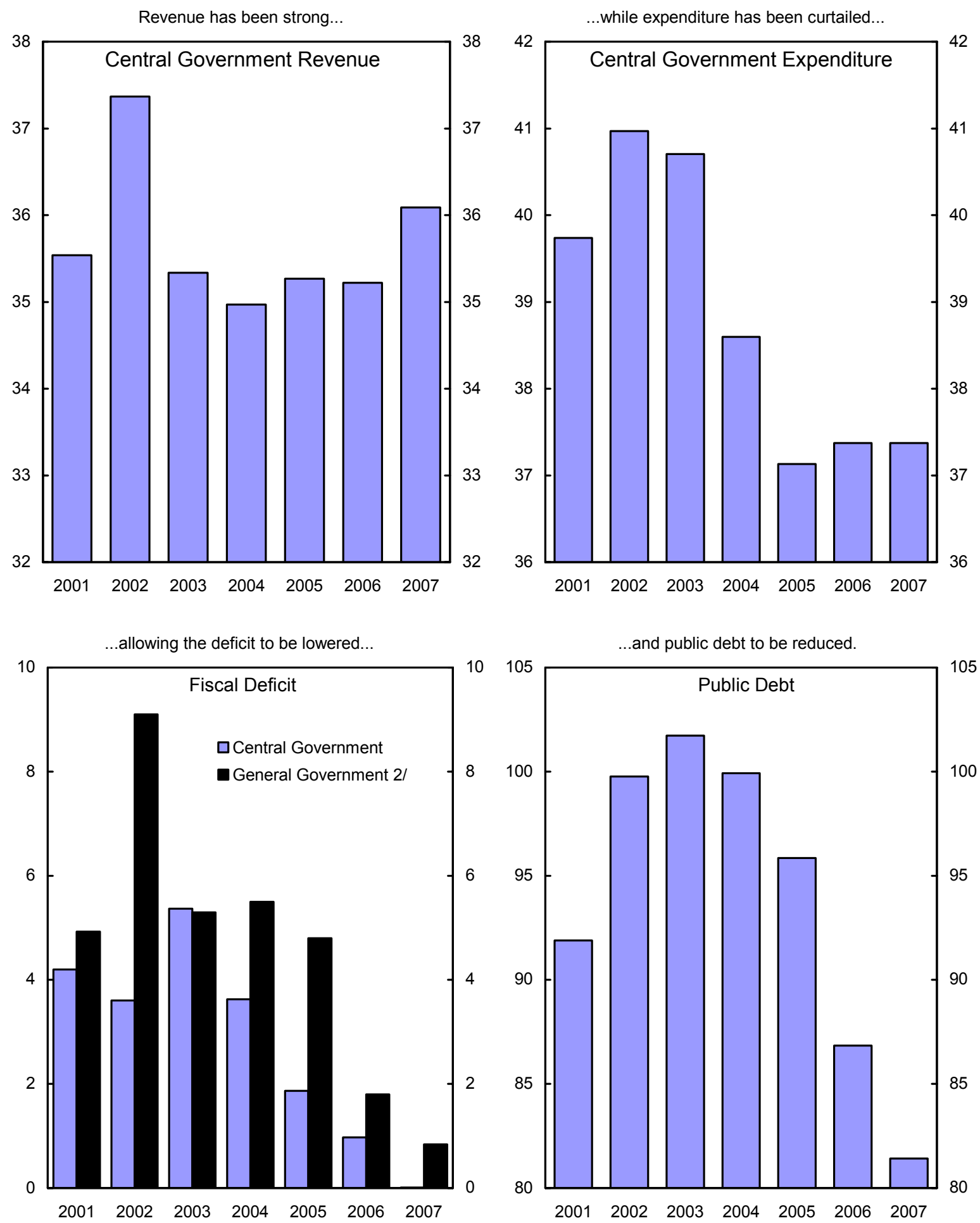

Sources: Ministry of Finance, national definition; and IMF staff estimates.

1/ Budget data for 2007.

2/ International definition, accrual basis. 
Figure 9. OECD: Tax Rates and Complexity $1 /$
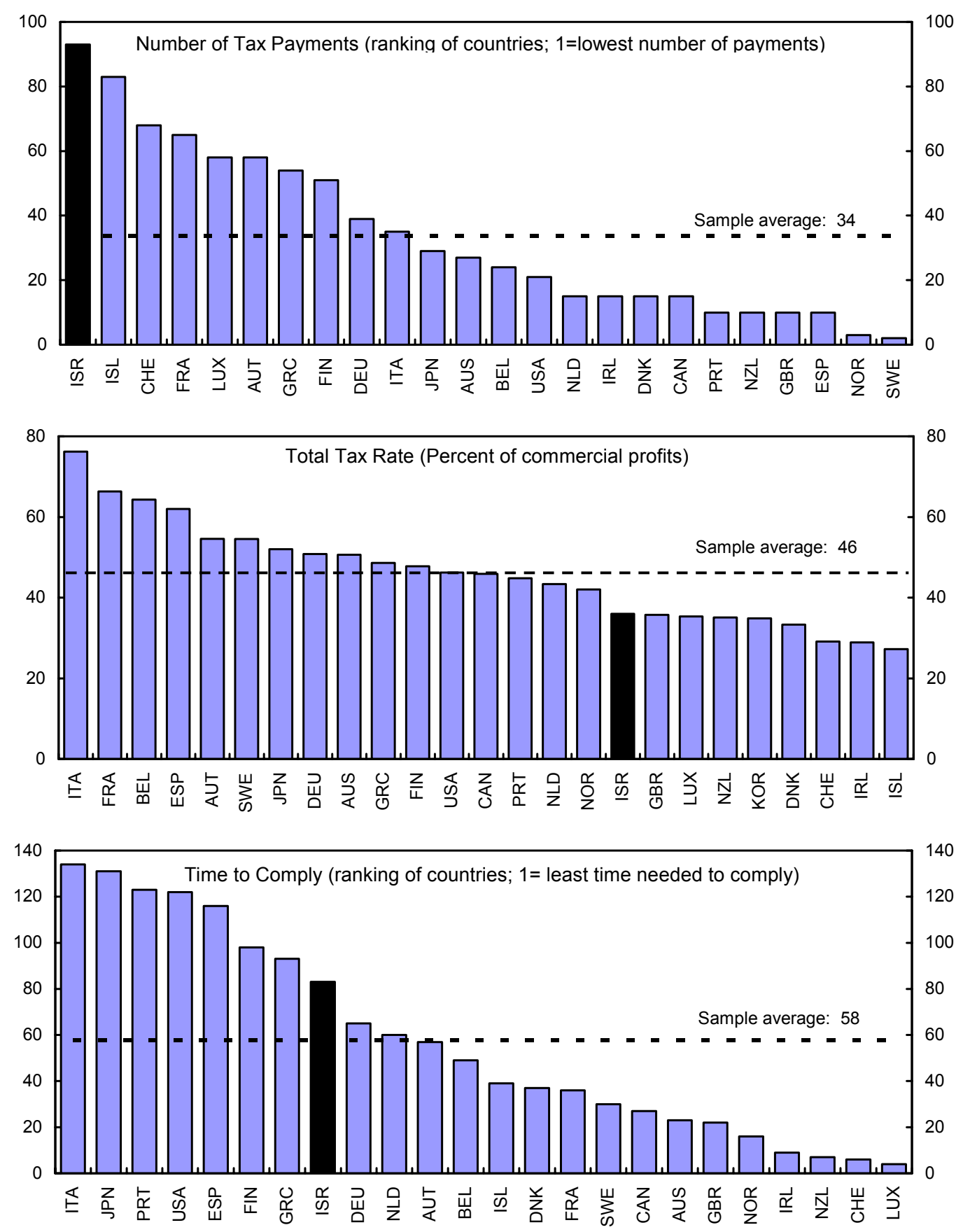

Source: World Bank and PricewaterhouseCoopers LLP, Paying Taxes 2008.

1 / For a medium-sized limited liability company in the second year of its operation. 
Table 1. Israel: Selected Economic and Financial Indicators, 2001-08

(Percent change, unless otherwise indicated)

\begin{tabular}{|c|c|c|c|c|c|c|c|c|}
\hline & 2001 & 2002 & 2003 & 2004 & 2005 & 2006 & $20071 /$ & $20081 /$ \\
\hline \multicolumn{9}{|l|}{ National accounts indicators (constant prices) } \\
\hline Domestic demand & 1.9 & -0.3 & -1.2 & 2.9 & 4.9 & 4.1 & 5.9 & 4.3 \\
\hline Private consumption & 2.8 & 0.8 & 1.2 & 5.6 & 4.0 & 4.5 & 6.2 & 4.5 \\
\hline Public consumption & 3.7 & 5.0 & -2.3 & -2.5 & 2.9 & 2.3 & 2.0 & 2.0 \\
\hline Gross capital formation & -3.1 & -10.6 & -6.0 & 3.1 & 11.1 & 5.3 & 10.5 & 6.5 \\
\hline Fixed capital formation & -3.4 & -6.5 & -5.6 & -0.4 & 2.3 & 10.1 & 10.4 & 3.8 \\
\hline Imports of goods and services & -5.1 & -1.1 & -1.3 & 11.8 & 3.5 & 3.3 & 9.4 & 6.4 \\
\hline Exports of goods and services & -11.1 & -2.0 & 8.0 & 18.1 & 4.3 & 5.9 & 8.0 & 5.3 \\
\hline Real GDP & -0.4 & -0.6 & 2.3 & 5.2 & 5.3 & 5.2 & 5.4 & 3.8 \\
\hline Output Gap & 0.0 & -1.6 & -2.8 & -1.7 & -1.0 & -0.3 & 0.6 & 0.4 \\
\hline \multicolumn{9}{|l|}{ Savings and investment (current prices, percent of GDP) } \\
\hline Gross capital formation & 20.5 & 18.8 & 17.6 & 17.8 & 19.0 & 18.9 & 20.2 & 20.8 \\
\hline Of which: public 2/ & 1.7 & 1.8 & 2.0 & 2.3 & 2.0 & 1.9 & 2.0 & 1.9 \\
\hline Savings & 19.5 & 17.9 & 18.0 & 18.9 & 20.4 & 22.2 & 22.5 & 21.8 \\
\hline Private & 21.3 & 19.8 & 22.5 & 21.5 & 21.2 & 22.0 & 21.3 & 20.8 \\
\hline \multicolumn{9}{|l|}{ Labor market indicators } \\
\hline Israeli civilian labor force & 1.2 & -0.3 & 1.6 & 3.6 & 5.4 & 3.8 & 4.3 & 3.9 \\
\hline Employment & 1.8 & 0.8 & 2.1 & 3.1 & 3.8 & 3.2 & 3.3 & 3.1 \\
\hline Unemployment rate (percent) & 9.3 & 10.3 & 10.8 & 10.4 & 9.0 & 8.4 & 7.5 & 6.8 \\
\hline Real wages $3 /$ & 3.0 & -6.2 & -3.0 & 2.5 & 1.0 & 1.3 & 2.7 & $\ldots$ \\
\hline Business sector $3 /$ & 3.3 & -6.6 & -2.5 & 1.5 & 1.5 & 1.7 & 3.1 & $\ldots$ \\
\hline Public sector $3 /$ & 2.6 & -4.9 & -4.1 & 4.6 & 0.0 & 0.3 & 1.6 & $\ldots$ \\
\hline \multicolumn{9}{|l|}{ Prices } \\
\hline CPI (end period) & 1.4 & 6.5 & -1.9 & 1.2 & 2.4 & -0.1 & 3.0 & 2.0 \\
\hline $\mathrm{CPI}$ (period average) & 1.1 & 5.7 & 0.7 & -0.4 & 1.3 & 2.1 & 0.5 & 2.7 \\
\hline CPI (excluding housing and energy, end period) & 0.4 & 3.7 & 2.0 & 0.0 & 1.1 & 2.4 & $\ldots$ & $\ldots$ \\
\hline Interest rates (average, percent): $\mathrm{BOI}$ policy rate 4/ & 6.8 & 6.8 & 7.5 & 4.2 & 3.7 & 5.1 & 3.9 & 4.3 \\
\hline \multicolumn{9}{|l|}{ Money and credit (period average) } \\
\hline Private sector credit $5 /$ & 14.3 & 11.7 & -3.1 & 3.9 & 7.1 & 4.3 & 7.7 & $\ldots$ \\
\hline \multicolumn{9}{|l|}{ Public finance (percent of GDP) } \\
\hline Central government revenue & 35.5 & 37.4 & 35.3 & 35.0 & 35.3 & 35.2 & 36.1 & 35.8 \\
\hline Central government expenditure & 39.7 & 41.0 & 40.7 & 38.6 & 37.1 & 36.2 & 36.1 & 36.2 \\
\hline Central government balance $8 /$ & -4.2 & -3.6 & -5.4 & -3.6 & -1.9 & -1.0 & 0.0 & -0.4 \\
\hline General government revenue & 46.9 & 47.2 & 44.9 & 44.3 & 43.9 & 44.7 & 45.5 & 45.2 \\
\hline General government expenditure & 51.8 & 56.3 & 50.2 & 49.8 & 48.7 & 46.5 & 46.4 & 46.5 \\
\hline General government balance $9 /$ & -4.9 & -9.1 & -5.3 & -5.5 & -4.8 & -1.8 & -0.8 & -1.3 \\
\hline General government primary balance & 1.4 & 0.7 & -1.1 & 1.0 & 2.2 & 3.0 & 4.0 & 3.5 \\
\hline General government structural primary balance & 1.6 & 1.8 & 0.7 & 2.1 & 2.9 & 3.3 & 3.7 & 3.6 \\
\hline General government debt & 91.9 & 99.8 & 101.7 & 99.9 & 95.9 & 86.8 & 81.4 & 77.7 \\
\hline \multicolumn{9}{|l|}{ Balance of payments } \\
\hline Trade balance (percent of GDP) & -3.1 & -4.1 & -2.7 & -2.3 & -2.9 & -2.3 & -4.0 & -5.5 \\
\hline Current account (percent of GDP) & -1.1 & -0.8 & 1.2 & 2.4 & 3.3 & 5.6 & 3.6 & 2.4 \\
\hline Foreign direct investment (percent of GDP) & 3.0 & 1.5 & 3.3 & 1.6 & 3.6 & 10.1 & 4.4 & 3.0 \\
\hline Foreign reserves (end period, billions of U.S. dollars) 6/ & 23.5 & 24.2 & 26.5 & 27.2 & 28.3 & 29.4 & 28.4 & $\ldots$ \\
\hline \multicolumn{9}{|l|}{ Exchange rate and terms of trade indices } \\
\hline NEER (period average) 5/ & 1.0 & -12.6 & -3.7 & -3.3 & -0.8 & 0.4 & 0.1 & $\ldots$ \\
\hline REER (period average) $5 /$ & -0.9 & -9.6 & -5.3 & -6.0 & -2.2 & 0.0 & -0.7 & $\ldots$ \\
\hline Terms of trade (index, $2000=100$ ) & 98.9 & 99.3 & 97.9 & 96.0 & 96.5 & 95.3 & $\ldots$ & $\ldots$ \\
\hline
\end{tabular}

Sources: Bank of Israel, Annual Report; Central Bureau of Statistics; IMF, International Financial Statistics; and IMF staff estimates and projections.

1/ IMF staff projections.

2/ Capital expenditure of the central government.

3/ Data for 2007 as of September.

4/ Data for 2008 as of January.

5/ Data for 2007 as of October.

6/ Data for 2007 as of December.

7/ Data for 2007 as of August.

8/ National definition, cash basis.

9/ International definition, accrual basis. On the difference between central and general government deficits during 2003-06: much of it is accounted for by the difference between accrual and cash bases accounting. On the latter, the key factor is the CPI indexation component that is paid on all NIS debt when it matures and is recorded below the line in the central government balance but above the line in the general government balance when it accrues. 
Table 2. Israel: Financial Soundness Indicators, 2001-07

(Percent)

\begin{tabular}{|c|c|c|c|c|c|c|c|c|}
\hline & \multirow[t]{2}{*}{2001} & \multirow[t]{2}{*}{2002} & \multirow[t]{2}{*}{2003} & \multirow[t]{2}{*}{2004} & \multirow[t]{2}{*}{2005} & \multirow[t]{2}{*}{2006} & \multicolumn{2}{|c|}{2007} \\
\hline & & & & & & & Mar. & Jun. \\
\hline \multicolumn{9}{|l|}{ Core Set } \\
\hline \multicolumn{9}{|l|}{ Deposit Takers } \\
\hline Regulatory capital to risk-weighted assets & 9.4 & 9.9 & 10.3 & 10.8 & 10.7 & 10.8 & 11.0 & 11.1 \\
\hline Regulatory Tier 1 capital to risk-weighted assets & 6.4 & 6.6 & 6.9 & 7.3 & 7.1 & 7.4 & 7.6 & 7.7 \\
\hline Problem loans to total credit & $\ldots$ & $\ldots$ & 10.5 & 10.5 & 9.5 & 8.4 & 8.1 & $\ldots$ \\
\hline Nonperforming loans net of provisions to capital & $\ldots$ & 35.1 & 33.3 & 31.0 & 27.2 & 21.2 & 20.3 & 18.7 \\
\hline Nonperforming loans to total gross loans & $\ldots$ & 2.4 & 2.6 & 2.5 & 2.3 & 1.9 & 1.9 & 1.8 \\
\hline \multicolumn{9}{|l|}{ Of which: } \\
\hline Other financial corporations (OFCs) & 7.2 & 7.6 & 7.2 & 7.9 & 8.7 & 8.7 & 9.1 & 9.2 \\
\hline General government & 3.6 & 3.5 & 3.3 & 2.7 & 2.5 & 2.2 & 2.1 & 2.0 \\
\hline Nonfinancial corporations (NFCs) & 50.2 & 49.7 & 48.1 & 44.7 & 43.4 & 41.9 & 41.9 & 42.1 \\
\hline Other domestic sectors & 24.5 & 24.7 & 26.0 & 28.4 & 28.5 & 29.3 & 28.8 & 28.2 \\
\hline Nonresidents & 14.4 & 14.5 & 15.4 & 16.2 & 16.9 & 17.8 & 18.0 & 18.4 \\
\hline Return on assets & 0.6 & 0.3 & 0.7 & 1.0 & 1.1 & 1.0 & 1.2 & 1.2 \\
\hline Return on equity & 12.3 & 6.1 & 14.1 & 17.9 & 19.4 & 17.6 & 19.7 & 20.2 \\
\hline Interest margin to gross income & 63.5 & 63.5 & 64.1 & 63.1 & 62.6 & 61.9 & 60.7 & 61.1 \\
\hline Noninterest expenses to gross income & 65.5 & 64.6 & 60.2 & 59.7 & 61.7 & 66.2 & 62.3 & 61.4 \\
\hline Net open position in foreign exchange to capital & -0.5 & 4.3 & 2.1 & 4.1 & -0.5 & 1.8 & 3.0 & -4.2 \\
\hline \multicolumn{9}{|l|}{ Encouraged Set } \\
\hline \multicolumn{9}{|l|}{ Deposit Takers } \\
\hline Capital to assets & 4.9 & 4.9 & 5.3 & 5.5 & 5.6 & 5.9 & 6.0 & 6.2 \\
\hline Gross asset position in financial derivatives to capital & $\ldots$ & $\ldots$ & 36.0 & 32.5 & 28.7 & 24.6 & 21.9 & 22.9 \\
\hline Gross liability position in financial derivatives to capital & $\ldots$ & $\ldots$ & 32.4 & 31.6 & 29.3 & 21.3 & 19.1 & 22.5 \\
\hline Trading income to total income & 36.4 & 19.4 & 12.3 & 17.9 & 23.7 & 8.8 & $\ldots$ & $\ldots$ \\
\hline Personnel expenses to noninterest expenses & 61.8 & 62.8 & 61.0 & 60.3 & 59.7 & 62.4 & 62.2 & 60.6 \\
\hline $\begin{array}{l}\text { Spread between reference lending and deposit rates } \\
\text { (basis points) }\end{array}$ & 1.5 & 2.3 & 2.0 & 2.7 & 3.0 & 3.5 & $\ldots$ & 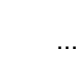 \\
\hline Customer deposits to total (non interbank) loans & 118.7 & 115.3 & 115.6 & 117.7 & 119.5 & 118.2 & 117.0 & 117.3 \\
\hline Foreign-currency-denominated loans to total loans & 34.8 & 36.0 & 35.4 & 34.5 & 31.4 & 28.1 & 28.0 & 28.6 \\
\hline $\begin{array}{l}\text { Foreign-currency-denominated liabilities to total } \\
\text { liabilities }\end{array}$ & 38.0 & 40.6 & 40.1 & 41.5 & 42.5 & 40.7 & 39.9 & 41.3 \\
\hline Net open position in equities to capital & 7.2 & 5.4 & 11.4 & 12.8 & 11.5 & 16.2 & $\cdots$ & ... \\
\hline \multicolumn{9}{|l|}{ Other Financial Corporations (OFCs) } \\
\hline OFCs' assets to total financial system assets & 35.4 & 35.5 & 38.1 & 40.0 & 42.3 & 42.4 & 42.3 & \\
\hline OFCs' assets to Gross Domestic Product (GDP) & 86.0 & 87.8 & 94.7 & 98.7 & 104.0 & 103.8 & 101.5 & \\
\hline \multicolumn{9}{|l|}{ Nonfinancial Corporations } \\
\hline Total debt to equity & 201.0 & 230.1 & 208.4 & 197.2 & 184.5 & 185.0 & 183.6 & 187.0 \\
\hline Return on equity & -8.6 & -3.2 & 5.2 & 11.6 & 16.6 & 13.1 & 15.6 & 15.7 \\
\hline Earnings to interest and principal expenses & 61.3 & 73.9 & 96.5 & 128.3 & 139.1 & 138.1 & 136.4 & 136.2 \\
\hline \multicolumn{9}{|l|}{ Households } \\
\hline Household debt to GDP & 27.1 & 28.1 & 28.3 & 27.7 & 27.9 & 30.7 & 30.1 & 30.2 \\
\hline \multicolumn{9}{|l|}{ Market Liquidity } \\
\hline $\begin{array}{l}\text { Average bid-ask spread in the } \\
\text { securities markets (percentage of mid-point price) }\end{array}$ & $\cdots$ & $\cdots$ & $\cdots$ & $\cdots$ & 0.0 & 0.0 & 0.0 & 0.0 \\
\hline Average daily turnover ratio in the securities markets & 0.6 & 0.9 & 0.9 & 0.9 & 0.8 & 0.9 & 0.9 & 0.9 \\
\hline \multicolumn{9}{|l|}{ Real Estate Markets } \\
\hline Residential real estate prices (annual percentage increas & 0.2 & 2.5 & -6.1 & -1.3 & 4.4 & -4.3 & -6.1 & 0.7 \\
\hline Residential real estate loans to total loans & 10.9 & 11.8 & 11.9 & 12.4 & 13.1 & 13.9 & 13.9 & 13.8 \\
\hline Commercial real estate loans to total loans & 18.2 & 18.2 & 17.9 & 16.6 & 16.1 & 16.0 & 16.1 & 16.2 \\
\hline
\end{tabular}

Source: Bank of Israel. 
Table 3. Israel: Balance of Payments, 2004-12

(Billions of U.S. dollars)

\begin{tabular}{|c|c|c|c|c|c|c|c|c|c|}
\hline & 2004 & 2005 & 2006 & $20071 /$ & $20081 /$ & $20091 / 2$ & $20101 /$ & $20111 /$ & $20121 /$ \\
\hline Current account balance & 3.0 & 4.3 & 8.0 & 5.6 & 4.0 & 3.8 & 4.2 & 4.4 & 4.8 \\
\hline Exports, f.o.b. & 36.7 & 40.1 & 43.7 & 49.3 & 53.4 & 56.1 & 59.3 & 62.7 & 66.6 \\
\hline Imports, f.o.b. & 39.5 & 43.9 & 47.0 & 55.5 & 62.6 & 65.2 & 68.5 & 72.1 & 76.5 \\
\hline Civilian imports & 37.6 & 41.7 & 44.5 & 53.0 & 60.0 & 62.4 & 65.5 & 68.9 & 73.1 \\
\hline Services & 3.2 & 3.7 & 4.3 & 3.4 & 4.3 & 3.9 & 4.6 & 5.3 & 6.0 \\
\hline Exports & 16.0 & 17.4 & 19.3 & 21.1 & 22.8 & 23.8 & 25.9 & 28.2 & 30.6 \\
\hline Imports & 12.8 & 13.7 & 14.9 & 17.7 & 18.5 & 19.8 & 21.3 & 22.9 & 24.6 \\
\hline Factor Income & -3.7 & -1.6 & -0.6 & 1.0 & 1.3 & 1.5 & 1.1 & 1.0 & 1.1 \\
\hline Receipts & 3.0 & 5.6 & 7.9 & 9.0 & 10.5 & 11.5 & 12.1 & 13.0 & 13.6 \\
\hline Payments & 6.7 & 7.2 & 8.5 & 8.0 & 9.3 & 10.0 & 11.0 & 12.0 & 12.5 \\
\hline Public & 3.5 & 3.2 & 4.4 & 4.1 & 4.0 & 4.0 & 4.0 & 4.0 & 4.0 \\
\hline Private & 2.8 & 2.8 & 3.0 & 3.4 & 3.6 & 3.6 & 3.6 & 3.6 & 3.6 \\
\hline Capital and financial account balance 2/ & -3.7 & -8.1 & -7.8 & -5.6 & -4.0 & -3.8 & -4.2 & -4.4 & -4.8 \\
\hline Capital account & 0.7 & 0.7 & 0.9 & 0.7 & 0.7 & 0.7 & 0.7 & 0.3 & 0.3 \\
\hline Financial account & -4.4 & -8.8 & -8.7 & -6.3 & -4.7 & -4.5 & -4.9 & -4.7 & -5.1 \\
\hline Direct investment, net & -2.5 & 1.9 & -0.1 & 1.0 & 1.0 & 1.0 & 1.0 & 3.0 & 3.0 \\
\hline Foreign direct investment (in Israel) & 2.0 & 4.8 & 14.3 & 7.0 & 5.0 & 3.0 & 3.0 & 4.2 & 4.2 \\
\hline Portfolio investment, net & 4.5 & -4.1 & -0.9 & -4.0 & -4.0 & -4.0 & -4.0 & -4.0 & -4.0 \\
\hline Other investment & -6.1 & -4.6 & -7.4 & -0.6 & -0.6 & -0.8 & -0.8 & -0.8 & -0.8 \\
\hline Change in reserves 3 / & -0.3 & -1.9 & -0.4 & -2.7 & -1.1 & -0.7 & -1.1 & -2.9 & -3.3 \\
\hline Errors and omissions & 0.7 & 3.7 & -0.2 & 0.0 & 0.0 & 0.0 & 0.0 & 0.0 & 0.0 \\
\hline \multicolumn{10}{|c|}{ Memorandum items (percent of GDP, unless otherwise indicated): } \\
\hline Current account balance & 2.4 & 3.3 & 5.6 & 3.6 & 2.4 & 2.2 & 2.2 & 2.2 & 2.2 \\
\hline GDP (billions of U.S. dollars) & 123.6 & 131.3 & 142.2 & 157.4 & 167.6 & 177.1 & 188.7 & 201.3 & 214.8 \\
\hline
\end{tabular}

Source: Central Bureau of Statistics, Monthly Bulletin of Statistics.

1/ IMF staff estimates and projections.

2/ Excludes reserve assets.

3/ Negative (positive) sign denotes increase (decrease) in reserves. 
Table 4. Israel: Indicators of External and Financial Sector Vulnerability, 2001-07

(Percent of GDP, unless otherwise indicated)

\begin{tabular}{|c|c|c|c|c|c|c|c|c|}
\hline & \multirow[b]{2}{*}{2001} & \multirow[b]{2}{*}{2002} & \multirow[b]{2}{*}{2003} & \multirow[b]{2}{*}{2004} & \multirow[b]{2}{*}{2005} & \multirow[b]{2}{*}{2006} & \multicolumn{2}{|c|}{ Latest Data } \\
\hline & & & & & & & 2007 & Date \\
\hline Broad money (percent change, 12-month basis) & 15.5 & 6.1 & 2.2 & 4.6 & 7.9 & 7.4 & 16.2 & Aug-07 \\
\hline Private sector credit (percent change, 12 month basis) & 14.3 & 11.7 & -3.1 & 3.9 & 7.1 & 4.3 & 7.7 & Oct-07 \\
\hline \multicolumn{9}{|l|}{ External Indicators } \\
\hline Terms of trade (average, percent change) $1 /$ & -1.2 & 0.5 & -1.5 & -1.9 & 0.6 & $-1.3 \ldots$ & & Proj. \\
\hline Gross official reserves (end period, billions of U.S. dollars) & 23.5 & 23.7 & 25.8 & 26.6 & 27.9 & 29.1 & 28.4 & Dec-07 \\
\hline Official reserves in months of imports of goods and nonfactor services & 6.5 & 6.8 & 7.1 & 6.2 & 5.9 & 5.7 & 5.0 & Proj. \\
\hline Total gross external debt/GDP (percent) & 54.7 & 63.3 & 60.6 & 60.7 & 56.7 & 58.5 & 53.3 & Proj. \\
\hline Total net external debt/GDP (percent) & 0.1 & -0.6 & -5.7 & -9.6 & -16.7 & -24.2 & -23.8 & Sep-07 \\
\hline Country risk ratings (S. \& P. / Moody's) $2 /$ & A- / A2 & A- / A2 & A- / A2 & A- / A2 & A- / A2 & A- / A2 & A / A2 & \\
\hline Exchange rate (per U.S. dollar, period average) & 4.20 & 4.74 & 4.55 & 4.48 & 4.48 & 4.45 & 3.91 & Dec-07 \\
\hline
\end{tabular}

Sources: Bank of Israel; Central Bureau of Statistics; and IMF staff estimates and projections.

1/ According to WEO GEE trade deflators.

2/ On foreign currency long-term debt, Moody's upgrade in July 2000. 
Table 5. Israel: External Debt Sustainability Framework, 2002-12

(Percent of GDP, unless otherwise indicated)

\begin{tabular}{|c|c|c|c|c|c|c|c|c|c|c|c|}
\hline \multicolumn{5}{|c|}{ Actual } & \multicolumn{7}{|c|}{ Projections } \\
\hline 2002 & 2003 & 2004 & 2005 & 2006 & 2007 & 2008 & 2009 & 2010 & 2011 & 2012 & $\begin{array}{l}\text { Debt-stabilizing } \\
\text { non-interest } \\
\text { current account 6/ }\end{array}$ \\
\hline
\end{tabular}

Baseline: external debt

Change in external debt

Identified external debt-creating flows $(4+8+9)$

Current account deficit, excluding interest payments

Deficit in balance of goods and services

Exports

Imports

Net non-debt creating capital inflows (negative)

Automatic debt dynamics 1/

Contribution from nominal interest rate

Contribution from real GDP growth

Contribution from price and exchange rate changes 2/

Residual, incl. change in gross foreign assets (2-3) $3 /$

External debt-to-exports ratio (percent)

Gross external financing need (billions of U.S. dollars) 4/

Percent of GDP

Scenario with key variables at their historical averages 5/

$\begin{array}{rrrrr}63.3 & 60.6 & 60.7 & 56.7 & 58.5 \\ 8.6 & -2.7 & 0.1 & -4.0 & 1.9 \\ 4.6 & -6.7 & -7.2 & -11.2 & -12.3 \\ -2.4 & -4.3 & -5.4 & -6.1 & -8.5 \\ 3.1 & 0.8 & -0.3 & 0.0 & -0.8 \\ 36.0 & 37.6 & 42.6 & 43.8 & 44.3 \\ 39.2 & 38.4 & 42.3 & 43.8 & 43.5 \\ -1.0 & -1.9 & -1.0 & -4.3 & -2.3 \\ 7.9 & -0.5 & -0.8 & -0.7 & -1.4 \\ 3.2 & 3.0 & 3.0 & 2.8 & 2.9 \\ 0.4 & -1.3 & -3.0 & -3.0 & -2.7 \\ 4.4 & -2.2 & -0.9 & -0.5 & -1.6 \\ 4.0 & 3.9 & 7.2 & 7.2 & 14.2 \\ 175.7 & 161.2 & 142.4 & 129.3 & 132.2 \\ 37.7 & 36.6 & 32.1 & 32.4 & 29.7 \\ 34.4 & 31.6 & 26.0 & 24.6 & 20.9\end{array}$

$\begin{array}{rrrrrr}53.3 & 50.3 & 50.4 & 50.1 & 49.5 & 48.7 \\ -5.3 & -3.0 & 0.1 & -0.4 & -0.6 & -0.7 \\ -9.2 & -6.9 & -3.8 & -3.8 & -4.8 & -4.8\end{array}$

$-1.5$

Key Macroeconomic Assumptions Underlying Baseline

Real GDP growth (percent)

GDP deflator in US dollars (change in percent)

Nominal external interest rate (percent)

Growth of exports (U.S. dollar terms, percent)

Growth of imports (U.S. dollar terms, percent)

Current account balance, excluding interest payments

Net non-debt creating capital inflows

$\begin{array}{rrrrrrrrrrr}-0.6 & 2.3 & 5.2 & 5.3 & 5.2 & 5.4 & 3.8 & 3.6 & 3.8 & 3.7 & 3.7 \\ -7.4 & 3.6 & 1.4 & 0.9 & 3.0 & 5.0 & 2.6 & 2.0 & 2.6 & 2.9 & 2.9 \\ 5.3 & 5.1 & 5.3 & 5.0 & 5.6 & 5.0 & 5.0 & 5.3 & 5.3 & 5.3 & 5.3 \\ -2.7 & 10.5 & 20.9 & 9.2 & 9.5 & 11.7 & 8.4 & 4.7 & 6.8 & 6.6 & 7.0 \\ -1.6 & 3.8 & 17.6 & 10.1 & 7.5 & 18.2 & 10.8 & 4.9 & 5.5 & 5.9 & 6.4 \\ 2.4 & 4.3 & 5.4 & 6.1 & 8.5 & 6.2 & 4.9 & 4.7 & 4.7 & 4.7 & 4.7 \\ 1.0 & 1.9 & 1.0 & 4.3 & 2.3 & 2.7 & 2.6 & -0.1 & -0.2 & 0.8 & 0.8\end{array}$

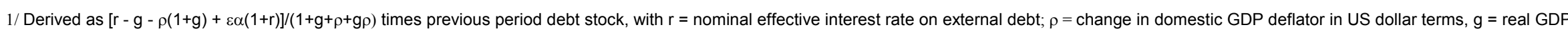
growth rate, $\mathrm{e}=$ nominal appreciation (increase in dollar value of domestic currency), and a = share of domestic-currency denominated debt in total external debt.

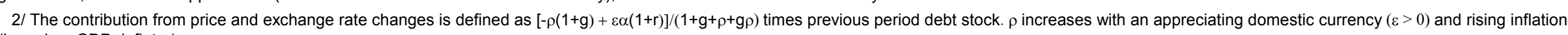
(based on GDP deflator).

3/ For projection, line includes the impact of price and exchange rate changes.

4/ Defined as current account deficit, plus amortization on medium- and long-term debt, plus short-term debt at end of previous period.

5/ The key variables include real GDP growth; nominal interest rate; dollar deflator growth; and both non-interest current account and non-debt inflows in percent of GDP.

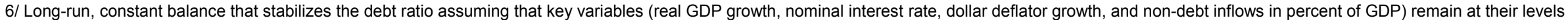
of the last projection year.

\section{CInternational Monetary Fund. Not for Redistribution}


Table 6. Israel: Public Sector Debt Sustainability Framework, 2002-12

(Percent of GDP, unless otherwise indicated)

\begin{tabular}{|c|c|c|c|c|c|c|c|c|c|c|c|c|}
\hline & \multicolumn{5}{|c|}{ Actual } & \multicolumn{6}{|c|}{ Projections } & \multirow[b]{2}{*}{$\begin{array}{c}\text { Debt-stabilizing } \\
\text { primary } \\
\text { balance } 9 /\end{array}$} \\
\hline & 2002 & 2003 & 2004 & 2005 & 2006 & 2007 & 2008 & 2009 & 2010 & 2011 & 2012 & \\
\hline $\begin{array}{l}\text { Baseline: public sector debt } 1 / \\
\text { Of which: foreign-currency denominated }\end{array}$ & $\begin{array}{l}99.8 \\
25.5\end{array}$ & $\begin{array}{r}101.7 \\
25.5\end{array}$ & $\begin{array}{l}99.9 \\
25.5\end{array}$ & $\begin{array}{l}95.9 \\
25.5\end{array}$ & $\begin{array}{l}86.8 \\
25.5\end{array}$ & $\begin{array}{l}81.4 \\
25.5\end{array}$ & $\begin{array}{l}77.7 \\
25.5\end{array}$ & $\begin{array}{l}74.4 \\
25.5\end{array}$ & $\begin{array}{l}70.8 \\
25.5\end{array}$ & $\begin{array}{l}66.7 \\
25.5\end{array}$ & $\begin{array}{l}62.2 \\
25.5\end{array}$ & 1.2 \\
\hline $\begin{array}{l}\text { Change in public sector debt } \\
\text { Identified debt-creating flows }(4+7+12)\end{array}$ & $\begin{array}{l}7.9 \\
5.5\end{array}$ & $\begin{array}{l}2.0 \\
3.1\end{array}$ & $\begin{array}{l}-1.8 \\
-1.2\end{array}$ & $\begin{array}{l}-4.1 \\
-0.9\end{array}$ & $\begin{array}{l}-9.0 \\
-6.4\end{array}$ & $\begin{array}{l}-5.4 \\
-3.4\end{array}$ & $\begin{array}{l}-3.7 \\
-3.0\end{array}$ & $\begin{array}{l}-3.3 \\
-2.9\end{array}$ & $\begin{array}{l}-3.6 \\
-3.2\end{array}$ & $\begin{array}{l}-4.1 \\
-3.7\end{array}$ & $\begin{array}{l}-4.5 \\
-4.2\end{array}$ & \\
\hline Primary deficit & -0.7 & 1.1 & -1.0 & -2.2 & -3.0 & -3.8 & -3.5 & -4.0 & -4.3 & -5.0 & -5.7 & \\
\hline Revenue and grants & 47.3 & 44.3 & 44.1 & 44.0 & 44.7 & 45.5 & 45.2 & 44.9 & 44.6 & 44.6 & 44.6 & \\
\hline Primary (noninterest) expenditure & 46.7 & 45.3 & 43.1 & 41.8 & 41.6 & 41.7 & 41.7 & 40.9 & 40.2 & 39.5 & 38.9 & \\
\hline Automatic debt dynamics $2 /$ & 3.9 & 2.2 & 0.5 & 1.1 & -3.9 & 0.6 & -0.1 & 0.6 & 0.7 & 1.0 & 1.2 & \\
\hline Contribution from interest rate/growth differential 3/ & 2.0 & 4.2 & 0.9 & -0.6 & -1.9 & 0.6 & -0.1 & 0.6 & 0.7 & 1.0 & 1.2 & \\
\hline Of which: contribution from real interest rate & 1.4 & 6.4 & 5.9 & 4.3 & 2.8 & 5.0 & 2.8 & 3.3 & 3.4 & 3.4 & 3.5 & \\
\hline Of which: contribution from real GDP growth & 0.6 & -2.2 & -5.0 & -5.0 & -4.6 & -4.5 & -2.9 & -2.7 & -2.7 & -2.5 & -2.3 & \\
\hline Contribution from exchange rate depreciation 4 / & 1.9 & -2.0 & -0.4 & 1.7 & -2.1 & $\ldots$ & $\ldots$ & $\ldots$ & $\ldots$ & $\ldots$ & $\ldots$ & \\
\hline Other identified debt-creating flows & 2.4 & -0.1 & -0.7 & 0.2 & 0.5 & -0.2 & 0.7 & 0.4 & 0.4 & 0.4 & 0.3 & \\
\hline Privatization receipts (negative) & -0.7 & -0.7 & -0.6 & -0.6 & -0.6 & -0.5 & -0.5 & -0.5 & -0.4 & -0.4 & -0.4 & \\
\hline Recognition of implicit or contingent liabilities & 0.2 & 0.2 & 0.2 & 0.2 & 0.2 & 0.2 & 0.1 & 0.1 & 0.1 & 0.1 & 0.1 & \\
\hline Other (specify, e.g. bank recapitalization) & 2.8 & 0.3 & -0.2 & 0.6 & 0.9 & 0.2 & 1.0 & 0.7 & 0.7 & 0.7 & 0.6 & \\
\hline Residual, including asset changes (2-3) 5/ & 2.4 & -1.1 & -0.6 & -3.2 & -2.6 & -2.0 & -0.7 & -0.4 & -0.4 & -0.4 & -0.3 & \\
\hline Public sector debt-to-revenue ratio $1 /$ & 210.7 & 229.9 & 226.8 & 218.0 & 194.5 & 178.8 & 172.0 & 165.8 & 158.8 & 149.7 & 139.6 & \\
\hline $\begin{array}{l}\text { Gross financing need 6/ } \\
\text { Billions of U.S. dollars }\end{array}$ & $\begin{array}{l}15.2 \\
16.6\end{array}$ & $\begin{array}{l}18.0 \\
20.9\end{array}$ & $\begin{array}{l}15.8 \\
19.5\end{array}$ & $\begin{array}{l}13.6 \\
17.9\end{array}$ & $\begin{array}{l}11.4 \\
16.2\end{array}$ & $\begin{array}{l}10.0 \\
15.8\end{array}$ & $\begin{array}{r}9.8 \\
16.4\end{array}$ & $\begin{array}{r}9.0 \\
16.0\end{array}$ & $\begin{array}{r}8.2 \\
15.6\end{array}$ & $\begin{array}{r}7.1 \\
14.4\end{array}$ & $\begin{array}{r}6.0 \\
12.9\end{array}$ & \\
\hline $\begin{array}{l}\text { Scenario with key variables at their historical averages } 7 / \\
\text { Scenario with no policy change (constant primary balance) in 2002-12 }\end{array}$ & & & & & & $\begin{array}{l}81.4 \\
81.4\end{array}$ & $\begin{array}{l}79.3 \\
77.5\end{array}$ & $\begin{array}{l}77.2 \\
74.4\end{array}$ & $\begin{array}{l}75.1 \\
71.3\end{array}$ & $\begin{array}{l}73.1 \\
68.5\end{array}$ & $\begin{array}{l}71.0 \\
65.9\end{array}$ & $\begin{array}{r}-0.4 \\
1.3\end{array}$ \\
\hline \multicolumn{13}{|l|}{ Key Macroeconomic and Fiscal Assumptions Underlying Baseline } \\
\hline Real GDP growth (percent) & -0.6 & 2.3 & 5.2 & 5.3 & 5.2 & 5.4 & 3.8 & 3.6 & 3.8 & 3.7 & 3.7 & \\
\hline Average nominal interest rate on public debt (percent) $8 /$ & 5.8 & 6.0 & 6.0 & 5.6 & 5.4 & 5.8 & 6.3 & 6.6 & 6.9 & 7.2 & 7.6 & \\
\hline Average real interest rate (nominal rate minus change in GDP deflator, percent) & 1.5 & 6.5 & 6.1 & 4.7 & 3.2 & 6.1 & 3.7 & 4.6 & 4.9 & 5.2 & 5.7 & \\
\hline Nominal appreciation (increase in U.S. dollar value of local currency, percent) & -6.8 & 8.2 & 1.6 & -6.4 & 8.9 & $\ldots$ & $\ldots$ & $\ldots$ & $\ldots$ & $\ldots$ & $\ldots$ & \\
\hline Inflation rate (GDP deflator, percent) & 4.3 & -0.5 & -0.1 & 1.0 & 2.2 & -0.2 & 2.6 & 2.0 & 2.0 & 2.0 & 2.0 & \\
\hline Growth of real primary spending (deflated by GDP deflator, percent) & 2.5 & -0.7 & 0.0 & 2.1 & 4.9 & 5.7 & 3.6 & 1.8 & 2.0 & 2.0 & 2.0 & \\
\hline Primary deficit & -0.7 & 1.1 & -1.0 & -2.2 & -3.0 & -3.8 & -3.5 & -4.0 & -4.3 & -5.0 & -5.7 & \\
\hline
\end{tabular}

$1 /$ Indicate coverage of public sector, e.g., general government or nonfinancial public sector. Also whether net or gross debt is used.

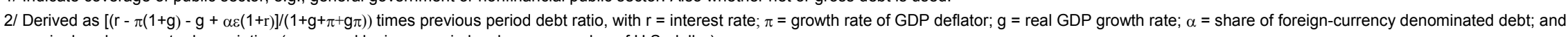
$\mathrm{e}=$ nominal exchange rate depreciation (measured by increase in local currency value of U.S. dollar).

$3 /$ The real interest rate contribution is derived from the denominator in footnote $2 /$ as $r-\pi(1+g)$ and the real growth contribution as $-g$.

4/ The exchange rate contribution is derived from the numerator in footnote $2 /$ as $\alpha \varepsilon(1+r)$.

5 / For projections, this line includes exchange rate changes.

6/ Defined as public sector deficit, plus amortization of medium and long-term public sector debt, plus short-term debt at end of previous period.

7/ The key variables include real GDP growth; real interest rate; and primary balance in percent of GDP.

8/ Derived as nominal interest expenditure divided by previous period debt stock.

9/ Assumes that key variables (real GDP growth, real interest rate, and other identified debt-creating flows) remain at the level of the last projection year.

\section{CInternational Monetary Fund. Not for Redistribution}


Table 7. Israel: Central Government Accounts, 2002-08

(Percent of GDP)

\begin{tabular}{|c|c|c|c|c|c|c|c|c|}
\hline & \multirow[t]{2}{*}{2002} & \multirow[t]{2}{*}{2003} & \multirow[t]{2}{*}{2004} & \multirow[t]{2}{*}{2005} & \multirow[t]{2}{*}{2006} & \multicolumn{2}{|c|}{2007} & \multirow{2}{*}{$\begin{array}{c}2008 \\
\text { Budget 3/ }\end{array}$} \\
\hline & & & & & & Budget 1/ & Proj. 21 & \\
\hline Revenue (excluding repayment of credit) & 37.4 & 35.3 & 35.0 & 35.3 & 35.2 & 33.7 & 36.1 & 34.0 \\
\hline Domestic & 32.6 & 31.7 & 32.1 & 32.6 & 33.0 & 31.5 & 34.2 & 32.0 \\
\hline Tax & 28.4 & 27.3 & 27.3 & 27.4 & 27.8 & 27.4 & 29.3 & 27.3 \\
\hline Of which: On income and profits & 15.4 & 14.5 & 14.4 & 14.9 & 15.6 & 15.1 & 16.5 & 14.9 \\
\hline On domestic goods and services & 13.0 & 12.8 & 12.9 & 12.6 & 12.1 & 12.3 & 12.8 & 12.4 \\
\hline Nontax & 4.2 & 4.4 & 4.8 & 5.2 & 5.2 & 4.2 & 4.9 & 4.7 \\
\hline Of which: Loans from the National Insurance Inst & 1.5 & 1.7 & 1.9 & 2.1 & 2.1 & 1.8 & 2.1 & 2.1 \\
\hline Other & 2.7 & 2.6 & 2.8 & 3.1 & 3.1 & 2.3 & 2.8 & 2.6 \\
\hline Foreign & 4.8 & 3.7 & 2.9 & 2.6 & 2.2 & 2.2 & 1.9 & 2.1 \\
\hline Of which: Grants & 2.9 & 2.0 & 1.9 & 1.9 & 2.0 & 1.7 & 1.6 & 1.5 \\
\hline Vat on defense imports & 0.4 & 0.3 & 0.2 & 0.3 & 0.2 & 0.2 & 0.2 & 0.3 \\
\hline Other & 1.5 & 1.4 & 0.7 & 0.4 & 0.1 & 0.3 & 0.0 & 0.3 \\
\hline $\begin{array}{l}\text { Expenditure (excluding lending } \\
\text { and expenditure by public hospitals) }\end{array}$ & 41.0 & 40.7 & 38.6 & 37.1 & 36.2 & 36.6 & 36.1 & 35.7 \\
\hline Current expenditure & 39.2 & 38.7 & 36.3 & 35.1 & 34.3 & 34.6 & 34.1 & 33.8 \\
\hline Wages & 8.3 & 8.3 & 8.1 & 8.1 & 8.0 & 7.7 & 7.7 & 7.6 \\
\hline Subsidies \& transfers & 13.7 & 13.8 & 13.1 & 12.5 & 14.2 & 12.2 & 12.2 & 11.9 \\
\hline Interest & 5.3 & 6.2 & 5.8 & 5.6 & 5.5 & 5.4 & 5.2 & 5.0 \\
\hline Other & 11.8 & 10.4 & 9.3 & 8.9 & 6.6 & 9.3 & 9.0 & 9.3 \\
\hline Capital expenditure & 1.8 & 2.0 & 2.3 & 2.0 & 1.9 & 2.0 & 2.0 & 1.9 \\
\hline Budget balance & -3.6 & -5.4 & -3.6 & -1.9 & -1.0 & -2.9 & 0.0 & -1.6 \\
\hline Financing & 3.6 & 5.4 & 3.6 & 1.9 & 1.0 & 2.9 & 0.0 & 1.6 \\
\hline Domestic (net) & 4.7 & 4.2 & 2.2 & -0.4 & -0.7 & 1.7 & -0.7 & 0.9 \\
\hline Foreign (net) & -0.4 & 1.2 & 1.4 & -0.4 & -0.3 & 0.0 & 0.9 & 0.7 \\
\hline Sale of assets (net) & 0.1 & 0.1 & 0.2 & 1.5 & 0.7 & 0.7 & 0.0 & 0.6 \\
\hline Change in cash balances and other financing (net) & -0.8 & -0.1 & -0.1 & 1.2 & 1.2 & 0.4 & -0.2 & -0.6 \\
\hline \multicolumn{9}{|l|}{ Memorandum item: } \\
\hline Defense expenditure & 11.2 & 10.3 & 9.1 & 8.8 & $\ldots$ & 7.8 & $\ldots$ & $\ldots$ \\
\hline Primary balance & 1.7 & 0.8 & 2.1 & 3.8 & 4.6 & 2.6 & 5.0 & 3.3 \\
\hline
\end{tabular}

Sources: Data provided by the Israeli authorities; and IMF staff estimates.

1/ Based on the proposed 2007 budget.

2/ Based on preliminary staff estimates and projected data from the authorities.

3/ Based on the proposed 2008 budget. 
Table 8. Israel: Medium-Term Scenarios, 2007-12

(Percent, unless indicated otherwise)

\begin{tabular}{|c|c|c|c|c|c|c|}
\hline & 2007 & 2008 & 2009 & 2010 & 2011 & 2012 \\
\hline GDP growth rate & 5.4 & 3.8 & 3.6 & 3.8 & 3.7 & 3.7 \\
\hline Inflation (average) & 0.5 & 2.7 & 2.0 & 2.0 & 2.0 & 2.0 \\
\hline \multicolumn{7}{|l|}{ Fiscal balance/GDP 1/ } \\
\hline Central government balance (baseline) 2/ & 0.0 & -0.4 & 0.0 & 0.4 & 1.0 & 1.7 \\
\hline Central government balance (alternative) 3/ & 0.0 & -0.4 & 0.0 & 0.0 & 0.0 & 0.0 \\
\hline Public debt/GDP (end of period) 2/ & 81.4 & 77.7 & 74.4 & 70.8 & 66.7 & 62.2 \\
\hline Public debt/GDP (end of period) 3/ & 81.4 & 77.7 & 74.4 & 71.4 & 68.5 & 65.9 \\
\hline Current account/GDP & 3.6 & 2.4 & 2.2 & 2.2 & 2.2 & 2.2 \\
\hline \multirow[t]{2}{*}{ Foreign reserves (billions of U.S. dollars) 4/ } & 29.0 & 31.3 & 31.7 & 32.2 & 33.7 & 35.3 \\
\hline & \multicolumn{6}{|c|}{ (Percent changes) } \\
\hline \multicolumn{7}{|l|}{ Memorandum Items: } \\
\hline Aggregate domestic demand & 5.9 & 4.3 & 3.4 & 3.4 & 3.4 & 3.4 \\
\hline Private consumption & 6.2 & 4.5 & 4.0 & 4.0 & 4.0 & 4.0 \\
\hline Public consumption & 2.0 & 2.0 & 2.0 & 2.0 & 2.0 & 2.0 \\
\hline Gross capital formation & 10.5 & 6.5 & 3.3 & 3.4 & 3.4 & 3.4 \\
\hline Exports of goods and services & 8.0 & 5.3 & 6.1 & 6.4 & 6.2 & 6.1 \\
\hline Imports of goods and services & 9.4 & 6.4 & 5.6 & 5.6 & 5.6 & 5.6 \\
\hline
\end{tabular}

Source: IMF staff estimates and projections.

1/ For the purpose of its budget deficit targets, the central government excludes net credit.

2/ Baseline scenario (2008-12) assumes the government adheres to the 1.7 percent growth in real expenditure, excluding war-related spending applicable in 2007-08.

$3 /$ Illustrative alternative scenario assumes the central government achieves zero deficit from 2010-12.

4/ Data for 2007 as of June. 


\section{INTERNATIONAL MONETARY FUND}

ISRAEL

\section{Staff Report for the 2007 Article IV Consultation-Informational Annex}

Prepared by the European Department

January 22,2008

Contents

Page

Appendixes

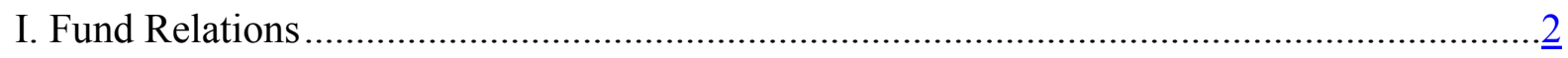

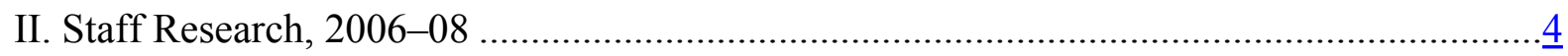


Appendix I. Israel: Fund Relations

(AS OF NOVEMBER 30, 2007)

I. Membership Status: Israel became a member of the Fund on July 12, 1954, and accepted the obligations of Article VIII, Sections 2, 3, and 4 on September 21, 1993, and, other than solely for national and international security reasons, maintains an exchange system free of restrictions on the making of payments and transfers for current international transactions. Israel subscribes to the SDDS and is in full observance of the SDDS's prescriptions for data coverage, periodicity and timeliness, and for the dissemination of advance release calendars. ${ }^{1}$

II. General Resources Account:

Quota

Fund holdings of currency

Reserve position in Fund

III. SDR Department:

Net cumulative allocation

Holdings
SDR Millions

928.20

867.56

60.65

SDR Millions

106.36

10.55
\% Quota

100.00

93.47

6.43

\% Allocation

100.00

9.91

IV. Outstanding Purchases and Loans: None

V. Financial Arrangements: None

VI. Projected Payments to Fund:

\begin{tabular}{|l|r|r|r|r|r|}
\hline \multicolumn{7}{|c|}{ Forthcoming } \\
\hline & 2007 & 2008 & 2009 & 2010 & 2011 \\
\hline Principal & & & & & \\
\hline Charges/Interest & & 3.41 & 3.40 & 3.40 & 3.40 \\
\hline Total & & 3.41 & 3.40 & 3.40 & 3.40 \\
\hline
\end{tabular}

VII. Implementation of HIPC Initiative: Not applicable

VIII. Safeguards Assessments: Not applicable

\footnotetext{
${ }^{1}$ For purposes of Fund relations, the West Bank and Gaza (WBG) fall under Israeli jurisdiction in accordance with Article XXXI, Section 2(g) of the Articles of Agreement.
} 
IX. Exchange Rate Arrangement:

As of June 9, 2005 Israel's exchange rate regime is officially classified as floating. This step by the Government of Israel was taken to remove the last vestige of a policy in which the exchange rate of the NIS fluctuated within the limits of a crawling band. In practice, however, the NIS has been floating since 1997, when the Bank of Israel stopped intervening to protect the band.

\section{Article IV consultation:}

The last Article IV consultation was concluded on January 19, 2007. Israel is on the standard 12-month consultation cycle.

\section{ROSCs:}

- Financial System Stability Assessment was conducted in 2000, issued in August 2001.

- Fiscal Transparency ROSC was conducted in 2003, issued in March 2004.

- AML/CFT ROSC was conducted in 2003, issued in June 2005.

- Data Module ROSC was conducted in 2005, and issued as IMF Country Report No. 06/125 in March 2006.

\section{Technical Assistance:}

The Fund has been providing policy advice and technical assistance to the Palestinian Authority since the 1993 Oslo Accords, and presently has a senior resident representative based in Jerusalem. The Fund's work in the West Bank and Gaza (WBG) has recently intensified, with a focus on the macroeconomic, fiscal, and financial areas. Staff missions to the WBG took place during May-August and November 2007 to assist the authorities in developing their medium-term macroeconomic and fiscal framework. That framework underpinned the Palestinian Reform and Development Plan (PRDP) presented at the Paris international donors' conference in December 2007. Looking forward, the Fund will be regularly reporting to donors on the macroeconomic and fiscal situation, and on the implementation of public finance reforms. Technical assistance will be stepped up in the areas of public expenditure management, banking supervision and regulation, and macroeconomic statistics.

\section{Resident Representative:}

A resident representative has been in the WBG since early 1996. 


\section{APPENDIX II. ISRAEL: STAFF RESEARCH, 2006-08}

\section{Monetary Policy}

"Endogenous Monetary Policy Credibility in a Small Macro Model of Israel," (Eyal Argov, Natan Epstein, Philippe Karam, Douglas Laxton, and David Rose. 2007, Working Paper).

- $\quad$ Extends a small linear model of the Israeli economy to allow for nonlinearities in the inflation-output process that arise from convexity in the Phillips curve and endogenous monetary policy credibility. Finds that the dynamic responses to shocks in the extended model more closely resemble features in the data from the recession period of 2001-03. In particular, the extended model does a much better job in accounting for the deterioration in monetary policy credibility and the output costs of regaining monetary policy credibility once it has been lost.

"A Simple Forecasting and Policy Analysis System for Israel: Structure and Applications," (Natan Epstein, Philippe Karam, Douglas Laxton, and David Rose. 2006, Selected Issues).

- $\quad$ Develops a simple forecasting and policy analysis system (FPAS) model to prepare baseline forecasts and risk assessments for monetary policy and the Israeli economy. The model is designed to support policy analysis for an inflation-targeting regime and captures the essential small, open, flexible-exchange-rate economy linkages between the policy rate and output, inflation and the exchange rate. Conducts risk assessments on three key sources of uncertainty underlying the baseline forecast - exchange rate, output gap, and oil prices — and reviews model properties and performance.

\section{Fiscal Policy}

"Toward a New Fiscal Rule: What Might Work Well for Israel," (Xavier Debrun and Natan Epstein. 2008, Selected Issues).

- $\quad$ Assess Israel's fiscal performance against its fiscal rules over the past two decades; reviews the international experience with fiscal rules; and proposes a new rule for Israel. In particular, recommends anchoring a new fiscal rule on the objective of lowering the public debt to 60 percent of GDP by 2015 .

"The Political Economy and Fiscal Institutions in Israel," (Mario Catalan. 2007, Selected Issues).

- Analyze the political economy factors that have affected fiscal policy and performance in Israel. Finds that fragmented parliaments and short average government duration have boosted public debt and deficits. Argues that strengthening fiscal governance mechanisms can counter political economy biases to fiscal policy, notably through enhanced budgetary transparency and analysis and independent fiscal policy assessment. 
"Fiscal Consolidation in Israel: A Global Fiscal Model Perspective," (Selim Elekdag, Natan Epstein, and Marialuz Moreno-Badía. 2006, Working Paper).

- $\quad$ Employs the IMF's Global Fiscal Model to quantify the costs of delaying fiscal consolidation in Israel. Finds that early consolidation through expenditure cuts would result in a substantial increase in Israel's long-term output growth relative to the case with delayed fiscal adjustment. Using an alternative fiscal instrument, it also finds that delaying tax cuts would result in long-run cumulative real GDP that is five times larger than when the tax cuts are immediately implemented.

\section{Financial Sector}

"Financial Sector Stability Analysis for Israel," (Martin Čihák. 2008, Selected Issues).

- $\quad$ Examines financial sector stability in Israel, focusing on market-based indicators and stress tests. Compared with the accounting ratios, market-based indicators paint a more mixed picture of recent financial stability developments in Israel, reflecting markets' assessment of challenges and risks associated with the recent financial sector reforms. The note also presents preliminary results of stress tests for banks, based on publicly available data. It finds that the banks have become more resilient to shocks over time, and that credit risk remains the key source of risk.

"Financial Sector Developments," (Ian Tower, Michael Moore and John Palmer, 2008, Selected Issues).

- Describes and analyses recent changes in the financial sector and financial regulation as they emerge from a period of major reform. Performance of the banks has been improving. Although one bank has incurred significant losses on assets related to the US mortgage market, the scope for further losses appears limited, provided that AAA mortgage-backed securities other than sub-prime are not significantly impaired. A key development in insurance has been the greater diversification of insurance groups. Overall the reforms have led to more diverse financial markets and appear to be generating benefits for the economy. It is also appropriate for the authorities to take stock of the results so far. Regulation of banking and insurance has been strengthened but further development is required, especially to build expertise for a more complex regulatory system and to consider the appropriate balance between a principles-based and a rules-based approach.

"Financial Sector Supervision Structures: Assessing the Alternatives for Israel," (Natan Epstein and Richard Pratt. 2007, Selected Issues).

- $\quad$ Reviews the international experience with various financial supervision structures. Examine the key advantages of the different models and provide a neutral assessment of the existing options. Highlights that any restructuring must provide for more independent supervision, supported by a strong governance structure; adequate 
resources for supervision; a strong regulatory capacity; and a level playing field across financial service industries.

"Corporate Balance Sheets and Investment: Empirical Estimates for Israel," (Marialuz Moreno. 2006, Selected Issues).

- Analyzes the empirical relationship between corporate leverage - and other indicators of financial health - and investment in Israel, using dynamic panel data techniques. Finds that weak balance sheets may well have contributed to the investment decline of recent years. Leverage, measured as the debt-to-assets ratio, is found to have a large negative effect on investment.

“The Reform of the Capital Markets in Israel," (Richard Pratt. 2006, Selected Issues).

- $\quad$ Reviews and analyzes the capital market reforms in Israel. Highlights that, together with the forced divestiture of banks' holdings of mutual and provident funds, actions that the authorities have taken to remove the legal, tax, and regulatory barriers to the further development of capital markets, are leading to growth and innovation in the creation of new instruments for investment and risk management. Maintains that the rapid development of the capital markets have created new supervisory and regulatory challenges.

"Banking Sector Developments and Issues," (Jonathan L. Fiechter, Michael Moore, John Palmer, and William Ryback. 2006, Selected Issues).

- $\quad$ Reviews developments and issues affecting the banking system in Israel and examines the supervision function by the Bank of Israel. Argues that while the banking system has grown stronger in recent years following the 2001-02 recession, the level of problem loans remained stubbornly high, contributing to a low level of profitability. Finds that the caliber of the BoI supervisors is strong and supervisors are highly qualified, but highlights the need to increase efficiency in the operations of the supervisory function.

\section{External Issues}

"Israel's External Competitiveness: Assessing the Real Exchange Rate," (Natan Epstein. 2008, Selected Issues).

- $\quad$ Finds that Israel's real exchange rate is moderately undervalued, while gains in external competitiveness appears to have been eroded somewhat in recent years. Various estimations suggest that the real exchange rate may be undervalued by about 5-10 percent. However, for various reasons the undervaluation may well be lower. 


\section{INTERNATIONAL MONETARY FUND}

\section{ISRAEL}

\section{Staff Report for the 2007 Article IV Consultation-Supplementary Information}

Prepared by the Staff Representatives for the 2007 Consultation with Israel

Approved by Michael Deppler and Michael Hadjimichael

February 8, 2008

This supplement contains information on recent economic developments in Israel that has become available since the circulation of the staff report for the Article IV consultation. The information does not alter the thrust of the staff appraisal.

\section{Following downward revisions to growth forecasts for the United States and} Europe, staff lowered its 2008 real GDP growth projection for Israel from 3.8 to 3.5 percent. While the latest conjunctural indicators do not show any weakness, the main reason for the downward revision is a fall in projected export growth, which would also slow investment and private consumption. Risks around the new projection are broadly balanced.

Change in Growth Rates Since Issuance of Staff Report, 2008

(Percent change, unless otherwise indicated)

\begin{tabular}{lcc}
\hline & Staff Report & Latest \\
\hline Real GDP & 3.8 & 3.5 \\
Exports of goods and services & 5.4 & 4.8 \\
Goods & 6.1 & 5.0 \\
Service & 5.1 & 4.7 \\
Private consumption & 4.5 & 4.2 \\
Investment (gross fixed capital formation) & 3.8 & 3.0 \\
Current account balance (percent of GDP) & 2.4 & 2.3 \\
\hline
\end{tabular}

Source: IMF staff projections.

\section{The consumer price index rose by a larger-than-expected 0.6 percent in}

December on a monthly basis. This brought the (end-of-period) inflation rate for 2007 to 3.4 percent, above the 3 percent upper limit of the Bank of Israel target range, which was also the rate projected by staff. One reason for this upside surprise is that recent sheqel appreciations appear to have had a less deflationary impact than staff and others had projected. ${ }^{1}$

\footnotetext{
${ }^{1}$ The standard assumption is that a 10 percent appreciation of the sheqel relative to the US dollar reduces prices by about 2 percent, but this appears to be diminishing.
} 
3. The sheqel has been appreciating since the issuance of the staff report, moving from a rate of 3.8 to close to 3.6 sheqel/US dollar. As a result, the sheqel is about 5 percent more appreciated than in staff's central scenario for 2008Q1 (Box 2), which should diminish inflationary pressure. In the meantime, markets foresee policy rate hikes of just under 0.5 percent by end-2008, while inflation expectations are around 2.5 percent. In the staff's view, the policy rate would probably have to be above the current 4.25 percent level once growth in trading partner countries reaccelerates, with a view to keeping inflation in the 1-3 percent target range.

However, the latest appreciation of the sheqel, external downside risks to activity, and heightened

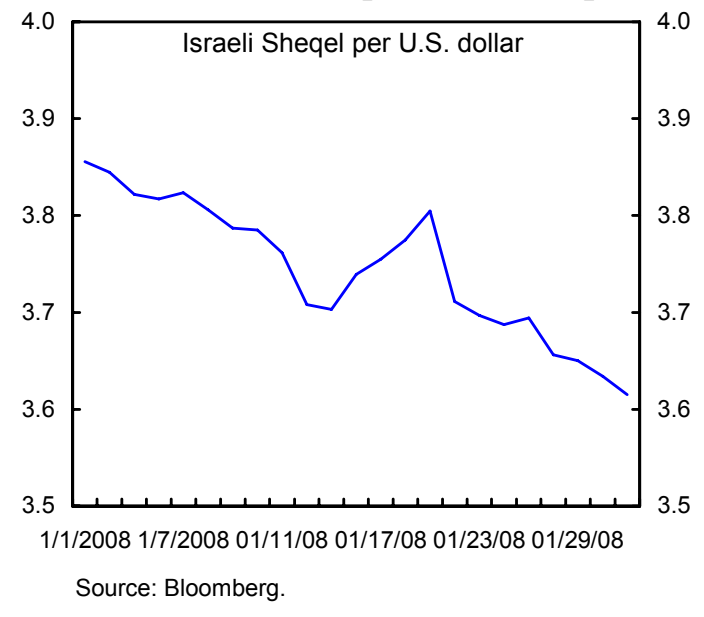
risk premia argue for caution in raising rates over the near term. 


\section{INTERNATIONAL MONETARY FUND}

Public Information Notice

EXTERNAL

RELATIONS

DEPARTMENT

Public Information Notice (PIN) No. 08/15

FOR IMMEDIATE RELEASE

February 14, 2008
International Monetary Fund

$70019^{\text {th }}$ Street, NW

Washington, D. C. 20431 USA

\section{IMF Executive Board Concludes 2007 Article IV Consultation with Israel}

On February 13, 2008, the Executive Board of the International Monetary Fund (IMF) concluded the Article IV consultation with Israel. ${ }^{1}$

\section{Background}

The economy is entering the global slowdown with significant momentum. Notwithstanding the war in the north during 2006, real GDP growth averaged about 51/4 percent during 2006-07. Buoyant world trade propelled exports and investment, fostering strong employment growthwhich was also supported by welfare reform-and private consumption.

Inflation undershot the 1-3 percent target in 2006 and in the first half of 2007, largely reflecting sheqel appreciation against the U.S. dollar, but rose in the second half of the year. In December 2007, prices stood 3.4 percent above the end-2006 level. The Bank of Israel (Bol) responded to the earlier declining price pressure by cutting the policy rate from a peak of 5.5 percent in October 2006 to 3.5 percent by June 2007 . With inflation reaccelerating and unemployment falling and the output gap closing, the Bol changed course in August 2007, raising rates in three steps, to 4.25 percent by January 2008.

Fiscal outturns have been much stronger than budgeted over the past couple of years because of higher-than-projected tax revenue and public expenditure restraint. As a result, the central government deficit has been kept well below the 3 percent of GDP deficit ceiling, falling to 1 percent of GDP in 2006 and reaching balance in 2007 . Nonetheless, public debt remains high

\footnotetext{
${ }^{1}$ Under Article IV of the IMF's Articles of Agreement, the IMF holds bilateral discussions with members, usually every year. A staff team visits the country, collects economic and financial information, and discusses with officials the country's economic developments and policies. On return to headquarters, the staff prepares a report, which forms the basis for discussion by the Executive Board. At the conclusion of the discussion, the Managing Director, as Chairman of the Board, summarizes the views of Executive Directors, and this summary is transmitted to the country's authorities.
} 
at just over 80 percent of GDP. For 2008-09, the central government deficit ceilings are 1.6 percent and 1.0 percent of GDP, respectively.

Indicators for the financial soundness of corporations and households have generally been improving but the global financial turmoil has caused some increase in risk premia. There have been losses on mortgage-related US assets but the effect on bank profitability and capital has been small thus far. Nor have banks been experiencing funding pressures. Concurrently, credit default swap (CDS) spreads on government bonds are up from unusually-low pre-crisis levels; and spreads between the returns on corporate and government bonds have widened, testifying to a general increase in risk premia.

Looking ahead, slowing demand from Israel's export partner countries is projected to reduce output growth in 2008 to around 31/2 percent, with broadly balanced risks. The ongoing shift from external to domestic sources of economic growth would further reduce the external current account surplus.

\section{Executive Board Assessment}

Executive Directors welcomed the Israeli economy's exceptional performance, which reflects both sound policy implementation and strong global growth. Directors observed that, while public debt has declined in recent years, its still elevated level leaves the economy vulnerable to shocks, and debt reduction remains a priority. They considered that further improvements to the financial sector framework would enhance the economy's resilience. Looking forward, Directors agreed that, with the domestic preconditions for buoyant activity in place, economic growth is likely to remain strong, although external conditions are becoming less supportive.

Directors observed that, given continued solid growth and growing capacity constraints, domestic inflationary pressure would probably mount, although the recent appreciation of the sheqel has lowered external inflationary pressure. They considered that, while interest rates may have to be at a higher level once external demand reaccelerates, external downside risks to activity and heightened risk premia argue for caution in raising rates over the near term.

Directors praised monetary policy for successfully stabilizing inflation expectations. They welcomed improvements in the transparency of policymaking, and encouraged the authorities to consider steps towards providing greater clarity on the role of macroeconomic forecasts in decision-making and on the monetary policy horizon. Directors recommended swift adoption of the draft Bank of Israel law, as it would strengthen the economy's institutional foundation. They agreed that the flexible exchange rate regime is serving Israel well.

Directors welcomed the strong fiscal policy performance that brought central government accounts into balance in 2007 . They viewed that, with activity projected to remain strong, the budget should be kept close to balance, to further reduce the public debt ratio and the economy's vulnerability to shocks. Accordingly, for 2008, Directors supported compliance with 
the 1.7 percent expenditure growth ceiling, tight budget execution, and the allocation of revenue overperformance to debt reduction.

Looking forward to 2009 and beyond, Directors generally welcomed the government's intention to stick with a rules-based approach to fiscal policy. A reformed rule that aims at reaching a 60 percent debt-to-GDP ratio by 2015 would be consistent with a debt level that is considered an upper limit in many less exposed advanced economies, and could also accommodate an increase in welfare spending. Directors agreed that debt reduction should be given precedence over tax cuts, and saw scope to simplify the relatively complex tax system, including through cutting tax exemptions.

Directors recommended enhanced fiscal transparency and governance to sustain the improved quality of policy making. Budget documentation could usefully include a multiyear scenario analysis of risks for public finance objectives, and a long-term fiscal sustainability analysis, which could help the public appreciate the importance of rapid debt reduction. Consideration could also be given to strengthening the governance of the fiscal framework by instituting independent, nonpartisan fiscal evaluation.

Directors concurred that the ambitious reforms of recent years, which foster the development of a more diversified financial system, may also raise new risks. They welcomed the improvement in financial soundness indicators, as well as ongoing work to adapt the prudential framework and financial infrastructure, while noting that major challenges still lie ahead. Directors noted the importance of giving regulators more scope to build the expertise necessary to support the increasingly complex regulatory system. Achieving consistency between the pace of regulatory change and high-quality implementation, and the right balance between principles-based and rules-based approaches to supervision will also be important. Directors underscored the value of strengthening the capacity of regulators to manage and resolve financial stress. They also viewed that the insurance supervisory authority should be granted independence in those areas where it is currently subject to constraints on its powers, in line with international standards.

\footnotetext{
Public Information Notices (PINs) form part of the IMF's efforts to promote transparency of the IMF's views and analysis of economic developments and policies. With the consent of the country (or countries) concerned, PINs are issued after Executive Board discussions of Article IV consultations with member countries, of its surveillance of developments at the regional level, of post-program monitoring, and of ex post assessments of member countries with longer-term program engagements. PINs are also issued after Executive Board discussions of general policy matters, unless otherwise decided by the Executive Board in a particular case. The staff report (use the free Adobe Acrobat Reader to view this pdf file) for the 2007 Article IV Consultation with Israel is also available.
} 
Israel: Selected Economic and Financial Indicators, 2003-08 (Percent change, unless otherwise indicated)

\begin{tabular}{|c|c|c|c|c|c|c|}
\hline & 2003 & 2004 & 2005 & 2006 & $20071 /$ & $20081 /$ \\
\hline \multicolumn{7}{|l|}{ National accounts indicators (constant prices) } \\
\hline Domestic demand & -1.2 & 2.9 & 4.9 & 4.1 & 5.9 & 4.0 \\
\hline Private consumption & 1.2 & 5.6 & 4.0 & 4.5 & 6.2 & 4.2 \\
\hline Public consumption & -2.3 & -2.5 & 2.9 & 2.3 & 2.0 & 2.0 \\
\hline Gross capital formation & -6.0 & 3.1 & 11.1 & 5.3 & 10.5 & 5.8 \\
\hline Fixed capital formation & -5.6 & -0.4 & 2.3 & 10.1 & 10.4 & 3.0 \\
\hline Imports of goods and services & -1.3 & 11.8 & 3.5 & 3.3 & 9.4 & 6.0 \\
\hline Exports of goods and services & 8.0 & 18.1 & 4.3 & 5.9 & 8.0 & 4.8 \\
\hline Real GDP & 2.3 & 5.2 & 5.3 & 5.2 & 5.4 & 3.5 \\
\hline \multicolumn{7}{|l|}{ Labor market indicators } \\
\hline Unemployment rate (percent) & 10.8 & 10.4 & 9.0 & 8.4 & 7.5 & 6.8 \\
\hline Real wages $2 /$ & -3.0 & 2.5 & 1.0 & 1.3 & 2.5 & $\ldots$ \\
\hline \multicolumn{7}{|l|}{ Prices } \\
\hline CPI (end period) & -1.9 & 1.2 & 2.4 & -0.1 & 3.4 & 2.0 \\
\hline $\mathrm{CPI}$ (period average) & 0.7 & -0.4 & 1.3 & 2.1 & 0.5 & 3.1 \\
\hline CPI (excluding housing and energy, end period) & 2.0 & 0.0 & 1.1 & 2.4 & 1.3 & $\ldots$ \\
\hline Interest rates (average, percent): $\mathrm{BOI}$ policy rate $3 /$ & 7.5 & 4.2 & 3.7 & 5.1 & 3.9 & 4.3 \\
\hline \multicolumn{7}{|l|}{ Money and credit (period average) } \\
\hline Private sector credit $2 /$ & -3.1 & 3.9 & 7.1 & 4.3 & 7.7 & $\ldots$ \\
\hline Narrow money (M1) 4/ & 0.5 & 18.0 & 17.5 & 13.7 & 15.4 & 18.8 \\
\hline Broad money (M3) $2 /$ & 2.2 & 4.6 & 7.9 & 7.4 & 15.9 & $\ldots$ \\
\hline \multicolumn{7}{|l|}{ Public finance (percent of GDP) } \\
\hline Central government revenue & 35.3 & 35.0 & 35.3 & 35.2 & 36.1 & 35.8 \\
\hline Central government expenditure & 40.7 & 38.6 & 37.1 & 36.2 & 36.1 & 36.3 \\
\hline Central government balance 5/ & -5.4 & -3.6 & -1.9 & -1.0 & 0.0 & -0.6 \\
\hline General government balance 6/ & -5.3 & -5.5 & -4.8 & -1.8 & -0.8 & -1.4 \\
\hline General government debt & 101.7 & 99.9 & 95.9 & 86.8 & 81.4 & 77.8 \\
\hline \multicolumn{7}{|l|}{ Balance of payments } \\
\hline Trade balance (percent of GDP) & -2.7 & -2.3 & -2.9 & -2.3 & -3.9 & -5.3 \\
\hline Current account (percent of GDP) & 1.2 & 2.4 & 3.3 & 5.6 & 3.5 & 2.3 \\
\hline Foreign direct investment (percent of GDP) & 3.3 & 1.6 & 3.6 & 10.1 & 4.3 & 2.9 \\
\hline Foreign reserves (end period, billions of U.S. dollars) 4 / & 26.5 & 27.2 & 28.3 & 29.4 & 30.7 & 28.5 \\
\hline \multicolumn{7}{|l|}{ Exchange rate and terms of trade indices } \\
\hline NEER (period average) $7 /$ & -3.7 & -3.3 & -0.8 & 0.4 & 2.7 & $\ldots$ \\
\hline REER (period average) 7/ & -5.3 & -6.0 & -2.2 & 0.0 & 1.8 & $\ldots$ \\
\hline Terms of trade (index, 2000=100) & 97.9 & 96.0 & 96.5 & 95.3 & $\ldots$ & $\ldots$ \\
\hline
\end{tabular}

Sources: Bank of Israel, Annual Report; Central Bureau of Statistics; IMF, International Financial Statistics; and IMF staff estimates and projections.

1/ IMF staff projections.

2/ Data for 2007 as of October.

3/ Data for 2008 as of February.

4/ Data for 2008 as of January.

$5 /$ National definition, cash basis.

6/ International definition, accrual basis. On the difference between central and general government deficits during 2003-06: much of it is accounted for by the difference between accrual and cash bases accounting. On the latter, the key factor is the CPI indexation component that is paid on all NIS debt when it matures and is recorded below the line in the central government balance, but above the line in the general government balance when it accrues.

7/ Data for 2007 as of November. 


\section{Statement by Age Bakker, Executive Director for Israel and Nir Klein, Senior Advisor to Executive Director February 13, 2008}

\section{General}

The Israeli authorities thank staff for the productive discussions in Jerusalem as well as for their well-written set of papers. They share staff's appraisal on the challenges ahead and broadly agree with the report's key recommendations.

Owing to global economic buoyancy and prudent economic policies, geared toward a freemarket economy, the Israeli economy continued to thrive in 2007, growing at above 5 percent for the fourth year consecutively. The robust economic performance was supported by high corporate profitability, prosperous financial markets and an increasing household income, which boosted business confidence and spurred private consumption and investment, as well as by the benign external conditions that contributed to a strong export performance. The current account surplus - although somewhat declining - remained at a comfortable level, and together with the high level of the net external asset position, underpinned the economy's external resilience. The positive developments in 2007 percolated to the labor market as the unemployment rate continued to decline, reaching the lowest level in decades, while the participation rate continued to grow. Fiscal policy remained responsible, keeping the central government budget at balance, and thus allowing a sharp reduction in the debt-toGDP ratio. On the monetary front, while opposing inflationary pressures shifted the inflation rate from a negative level in early 2007 to above the upper limit of the inflation target at the end of the year, the policy's high credibility kept inflationary expectations well anchored within the inflation target range, and thus continued to support price and financial stability.

The impressive momentum of Israel's economic activity was acknowledged by Standard and Poor's, which upgraded Israel's risk rating in November, and earlier in 2007 (May) by the OECD, which invited Israel to begin membership negotiations. ${ }^{1}$ That said, the authorities well recognize that Israel is not yet "out of the woods" as significant challenges remain, including the need to reduce the high debt-to-GDP ratio, closing social gaps and, in view of the recent structural change, further enhance the financial sector's resilience. In this regard, they remain committed to continue with prudent policies and underscore their intention to forcefully progress with their ambitious reform agenda to ensure a sustainable and high growth path for the economy.

\section{Macroeconomic developments and outlook}

In 2007, the Israeli economy continued the strong cyclical upswing that was recorded in the past three years. Overall, economic activity expanded by 5.3 percent (preliminary estimate) while the performance of the business sector was even stronger ( 6.3 percent). Strong

\footnotetext{
${ }^{1}$ A framework for carrying out the accession process (known as the "roadmap") was set by the OECD Council (December) and the authorities are now engaging with the OECD's various bodies in order to complete the accession process promptly.
} 
domestic demand, ${ }^{2}$ which benefited from supportive macroeconomic policies and benign business environment, generated a significant increase in imported investment and consumption goods and contributed to the decline of the current account surplus to 3.6 percent of GDP, despite strong export performance ( 8.6 percent). On the supply side, while in previous years growth was largely based on high productivity growth, a significant increase in labor and capital inputs became apparent in 2007. Indeed, the unemployment rate declined by 0.9 percentage points to 7.5 percent, while the participation rate increased to 56.4 percent, and fixed capital formation increased by 10.4 percent. The deceleration of productivity indicates that excess capacity is narrowing, and that a future increase in demands may result in higher inflationary pressures. In this context, signs of price pressures from the labor market are beginning to emerge as real wages rose this year by 2.7 percent, which is significantly higher than in the previous two years.

Looking ahead, the authorities broadly share the staff's assessment that the domestic fundamentals are solid and provide a firm platform for future expansion. They well recognize that growth performance is likely to be less strong than in previous years as capacity constraints are beginning to bind and external conditions are becoming less supportive. Accordingly, the authorities' baseline scenario suggests that 2008 GDP growth will be in a 4.2-4.4 percent range, assuming a moderate slowdown in global economic activity and no significant change in the geo-political situation. A more conservative scenario (3.6 percent), which in view of the recent global developments is becoming more realistic, is also being considered. The authorities are closely monitoring current developments and intend to revise their growth projections should conditions warrant that.

\section{Fiscal policy}

In 2007, the authorities continued with prudent fiscal policy-making and further progressed with fiscal consolidation. Buoyant revenues and strong fiscal discipline, as reflected in a tight expenditure envelope, led to a balanced central government budget, despite the ongoing implementation of the tax reform, in which corporate and personal income tax rates are being reduced, and the significant increase in defense-related spending following the conflict in the north. The balanced budget, coupled with robust GDP growth, contributed to a sharp reduction in the debt-to-GDP ratio to the level of 81 percent of GDP in 2007. This decline sums up an accumulated decrease of more than 20 percent in 4 years. In the same vein, the ongoing fiscal retrenchment continued to support the business sector's activity and was reflected in downsizing of the public sector to 46 percent of GDP, compared to 56 percent in 2002.

While being encouraged by the recent fast decline in debt-to-GDP ratio, the authorities recognize that its current level remains relatively high and needs to be further reduced to contain the remaining vulnerabilities. They agree with staff's view that reducing debt to GDP to the level of 60 percent over the medium term is an ambitious yet achievable goal and reiterate their intention to make every effort to progress in this direction. In this context, the

\footnotetext{
${ }^{2}$ According to early estimates, in 2007 , the private consumption and investment rose by 7.2 percent and 13.4 percent, respectively.
} 
authorities are in the process of redefining their fiscal policy rules. Accordingly, they intend to revise the current fiscal rules to ensure the continuation of debt reduction (as a share of GDP) in both good and bad times, while allowing a more sustainable path for public expenditures. The expectation is that new fiscal rules will be introduced and adopted in the course of this year and will take effect in the 2009 budget onwards.

In late December, the Knesset adopted the 2008 budget, which envisages a deficit of 1.6 percent of GDP and expenditure real growth of 1.7 percent, in line with earlier commitments. ${ }^{3}$ The authorities, nevertheless, underscore that the envisaged fiscal deficit should be regarded as a ceiling, and in fact, expect to end the year with a smaller deficit, as in the past few years. The budget envisages a significant increase in the public civil consumption (nearly 7 percent), which under the current tight expenditure rule, was possible due to the considerable reduction of public debt and its associated interest rate payments. The budget aims at closing social gaps, inter alia, by encouraging labor participation, reforming the education system and increasing the support to weak population.

In an effort to streamline the budgetary process and allow a far-reaching public debate on the budget components, the government has agreed to bring forward the submission of the budget proposal to the Knesset. The proposed 2009 budget will be submitted no later than 30 September 2008 and the proposed 2010 budget and future budgets will be submitted no later than 31 August. To further increase transparency and improve fiscal management, the MoF positively considers, in line with staff's recommendation, introducing a multi-year budgetary plan with an explicit analysis of potential risks.

\section{Monetary issues}

The opposing inflationary pressures, driven by both domestic and external factors, shifted, in 2007, the monetary stance from easing to tightening. In the first half of the year, the significant appreciation of the Sheqel, coupled with the decline in energy prices toward the end of 2006, exerted downward pressures on prices and brought the inflation rate in the last 12 months to a negative level. Consequently, the Bank of Israel (BoI) continued to maintain an accommodative monetary stance by gradually cutting the interest rate by 1 percent to 3.5 percent in June, thus allowing the US-Israel interest rate differential to reach its record-high level (1.75 percent). During this period, local components of the CPI continued to increase, yet their impact on the overall headline inflation was rather moderate. In the remainder of the year, the narrowing output gap and higher energy and food prices exerted greater inflationary pressures and pushed the inflation rate toward the upper limit of the inflation target range (13 percent). Accordingly, the BoI tightened the monetary stance and gradually raised the interest rate to 4 percent. In January 2008, the interest rate was raised again by additional $25 \mathrm{bp}$ following new indications about mounting inflationary pressures. The CPI recorded, during 2007, an overall increase of 3.4 percent. At present monetary policy has to take into account both the ongoing inflationary pressures from the closing of the output gap, and the

\footnotetext{
${ }^{3}$ In addition, the budget envisages one off spending to allow an increase in defense-related spending following the conflict in the north and to finance the remainder of the disengagement costs. This implies an additional spending growth of 1.5 percent.
} 
impacts on future inflation of the slowdown in global demand growth and the strengthening of the Sheqel. This caused the authorities to leave the interest rate for February unchanged, and leaves the future course of interest rates uncertain.

While the high variability of inflation underscores the complexity of monetary policymaking in a small and open economy such as Israel where exchange rate movements largely affect the pattern of prices, it is worth noting that inflation expectations for one and two years ahead remained relatively stable and, for most of 2007, fluctuated within the inflation target range. ${ }^{4}$ This serves as a testimony to the high credibility of the current flexible inflation targeting framework and the public's recognition that the $\mathrm{BoI}$ is committed to meet the inflation target at the medium term. The BoI is constantly making efforts to improve its communication and transparency. In this regard, it has started to publish its forecast about the interest rate path ${ }^{5}$ and intends, starting from 2008, to shift toward quarterly publication of Inflation Reports.

Following a protracted dispute over the wage structure at the BoI, an agreement was signed (December 2007) between the BoI and MoF and the labor union. It is expected that this agreement will pave the way for prompt adoption of the new BoI law as well as for the acceleration of the BoI's restructuring process, which will enhance the BoI's capacity and professional independence and place it in line with the best practice of central banks in advanced economies.

\section{Financial sector issues}

Israel's financial system is undergoing rapid reform-driven change. Accelerated financial deepening has fostered economic growth and has been reflected in a continuous improvement in financial sector's indicators. In this context, since 2004 there has been an improvement in banks' earnings, capital ratios, levels of NPLs and in loan-loss reserves, and even under an extreme stress-test scenario, the banking system is resilient. By and large, the current financial turmoil has had so far a relatively moderate impact on financial institutions' balance sheets due to their limited exposure and conservative investment approach. That said, the authorities are vigorously monitoring the banks and other financial institutions' exposures to structured products, and have required enhanced transparency in their financial statements.

The staff rightly points out that the recent capital market reform has generated significant challenges for supervisors as risks have shifted from banks to institutional investors and households. While a new inter-institutional (Ariav) committee was recently established to address the emerging challenges, the authorities have taken several steps to secure financial stability, inter alia by increasing markets' transparency and discipline as well as fostering greater competition and market sophistication. Among other measures, the authorities enacted a series of new regulations to facilitate switching between the supervised entities and choosing between different savings instruments and plans, and launched a website that enables comparison between provident funds and between pension funds. Additionally, following extensive discussions with commercial banks, the latter decided to exploit the

\footnotetext{
${ }^{4}$ Excluding April and May when inflation expectations slightly declined below 1 percent.

${ }^{5}$ The interest rate path and the associated uncertainties are described in a fan chart.
} 
benign macroeconomic conditions, and included in their business plans a gradual rise in capital ratios to the range of 12-13 percent (from 10-12 percent) within the next two years.

In May 2007, the authorities announced a Joint Work Plan for the Supervisor of Banks and Banks regarding implementation of Basel II. The plan has a twofold objective: enhancing the risk management, control systems and corporate governance of the banks as well as moving towards risk- and principles-based banking supervision. The authorities intend to devote substantial resources to this issue, including through hiring high-quality international experts, and they are conducting consultations with banks in order to implement Basel II by the end of 2009. In line with disclosure requirements of Basel II, the authorities published a new financial reporting directive on the measurement and disclosure of impaired loans and debt securities, credit risk and the allowance for credit risk. The directive improves the standards for measurement and disclosure of credit risks, in alignment with the advanced economies' standards, as well as the banks' ability to monitor and measure credit risks. The authorities share staff's appraisal that more is needed to improve their capacity to manage and resolve financial stress. To this end, the BoI's Governor established teams with the objective to prepare a manual on this issue.

\section{Structural reforms and social policy}

The authorities are continuing with their ambitious reform agenda to boost competitiveness and efficiency in the markets. In 2007, the government reduced its holding in the Pi-Glilot gas depot and completed the privatization process of the Israel Oil Refineries with the sale of the second oil refinery in Haifa. Further structural changes in the energy sector also include the government's intention to split the monopolistic Electric Corporation into several separated companies (transmission, generation and distribution) in order to improve efficiency and induce price reduction. Additional planned privatizations, which are currently in the stage of evaluation and assessment, include the Postal Authority, the Israeli Military Industries (IMI), the Israel Aircraft Industry (IAI) and the seaport in Eilat.

As for the social developments, the authorities are encouraged by the fact that after a continuous increase in poverty, the extent of the population living below the poverty line, has recorded a moderate decline.$^{6}{ }^{7}$ Nevertheless, the poverty level remains high and income inequality continues to be among the highest in the world. The government, in this regard, adopted (April 2007) the "Social-Economic Agenda for 2008-10", which sets explicit targets for poverty and the labor market participation rate. ${ }^{8}$ To achieve these targets the government intends to introduce in the course of 2008 an Earned Credit Income Tax (EITC), which subsidizes low wage working families, to expand vocational training in the context of

\footnotetext{
${ }^{6}$ The NII 2007 poverty report, which reviews the scale of poverty in 2006, shows that the population below the poverty line moderately declined by 0.6 to 20 percent (after welfare payments and taxes).

${ }^{7}$ It should be noted that the poverty measure in Israel is of relative poverty: a person is defined as being poor if his or her income is below half the median income. It is thus more a measure of income gaps than of absolute poverty.

${ }^{8}$ The two targets are gradually increasing the participation rate for ages $25-64$ by 2.6 percent to the OECD average ( 71.7 percent) and increasing the income of the lowest socio-economical quintile by 10 percent higher than the growth of GDP per capita until 2010.
} 
ALMP, subsidize day-care centers (to encourage mothers to join the labor market), to strengthen enforcement of labor laws and to reduce the number of illegal foreign workers. The new agreement between the labor union and the manufacturers association on a mandatory pension is also expected to contribute to poverty reduction over the medium and longer term. 